\title{
Starting From Refugees Themselves: A Study on the Resettlement of Government-Assisted Refugees in Gatineau, Québec
}

\author{
by \\ Christophe Allaire Sévigny
}

A thesis submitted to the Faculty of Graduate and Postdoctoral Affairs in partial fulfillment of the requirements for the degree of

Master of Arts

in

Sociology

Carleton University

Ottawa, Ontario

(C) 2011, Christophe Allaire Sévigny 
Library and Archives

Canada

Published Heritage

Branch

395 Wellington Street

Ottawa ON K1A ON4

Canada
Bibliotheque et

Archives Canada

Direction du

Patrimoine de l'édition

395 , rue Wellington

Ottawa ON K1A ON4

Canada
Your file Votre référence

ISBN: 978-0-494-83143-4

Our file Notre réfërence

ISBN: $978-0-494-83143-4$
NOTICE:

The author has granted a nonexclusive license allowing Library and Archives Canada to reproduce, publish, archive, preserve, conserve, communicate to the public by telecommunication or on the Internet, loan, distribute and sell theses worldwide, for commercial or noncommercial purposes, in microform, paper, electronic and/or any other formats.

The author retains copyright ownership and moral rights in this thesis. Neither the thesis nor substantial extracts from it may be printed or otherwise reproduced without the author's permission.
AVIS:

L'auteur a accordé une licence non exclusive permettant à la Bibliothèque et Archives Canada de reproduire, publier, archiver, sauvegarder, conserver, transmettre au public par télécommunication ou par l'internet, prêter, distribuer et vendre des thèses partout dans le monde, à des fins commerciales ou autres, sur support microforme, papier, électronique et/ou autres formats.

L'auteur conserve la propriété du droit d'auteur et des droits moraux qui protège cette thèse. $\mathrm{Ni}$ la thèse ni des extraits substantiels de celle-ci ne doivent être imprimés ou autrement reproduits sans son autorisation.
In compliance with the Canadian Privacy Act some supporting forms may have been removed from this thesis.

While these forms may be included in the document page count, their removal does not represent any loss of content from the thesis.
Conformément à la loi canadienne sur la protection de la vie privée, quelques formulaires secondaires ont été enlevés de cette thèse.

Bien que ces formulaires aient inclus dans la pagination, il n'y aura aucun contenu manquant. 


\begin{abstract}
This thesis examines refugee resettlement from the standpoint of GovernmentAssisted Refugees (GARs) and resettlement workers. While the existing literature on refugees tends to take a problem-solving approach, this thesis draws on the work of Dorothy Smith in order to explore refugee resettlement in Gatineau, Québec. This thesis pays attention to the participation of refugees in the resettlement process abroad and to the work of resettlement workers at its 'end point'. It is argued that refugees are not passive recipients of resettlement but are rather active in the process. This thesis highlights the difficult conditions under which resettlement workers operate and shows that there is an increasing tension between the needs of GARs and the resources available to resettlement workers to meet them. Finally, this thesis emphasizes the interconnectedness of the various institutional stages of resettlement and calls for more research on the relationship between its global and the local processes.
\end{abstract}




\section{Acknowledgements - Remerciements}

Ce mémoire est dédié aux réfugiés qui ont participé à cette recherche. Votre courage et votre résilience m'ont beaucoup inspiré. Merci de m'avoir si généreusement donné de votre temps et de m'avoir partagé vos histoires et vos pensées. I am deeply grateful to Daiva Stasiulis for her guidance, her encouragement, and her incredible availability: You were truly an exceptional supervisor. I would like to extend my sincere appreciation to James Milner who had been an incredible committee member: Thank you for your dedication and your enthusiasm. And thanks to Megan Bradley who had been an extraordinary external examiner. Merci à Bato Redzovic et à tous les employés d'Accueil-Parrainage Outaouais pour votre soutient et votre participation à la réussite de mon projet de recherche. Votre travail quotidien auprès des réfugiés et votre immense compassion est source d'inspiration pour moi. I would like to thank Richard Darville, Alan Hunt, Janet Siltanen, and Kevin Walby as well as Loretta Czernis, Cheryl Gosselin, and Michael Lustigman who at different times, provided me with comments on different pieces of writing that helped me frame this thesis. Un gros merci plein d'amour à mon frère Nathaniel ainsi qu'à David Plasse, Guillaume Poulin et Gabriel L'Écuyer pour leur soutient. Merci à Michel Gagnon pour son aide. I would also like to thank Dorothy Smith for being a constant source of inspiration and for the lovely discussion we had in Toronto during the summer of 2010 which helped me organize my thoughts about this research project. Les derniers mais non les moindres: Ani, Zoïk et Thierno. Sans toi Ani je n'y serais sans doute jamais arrivé. Merci pour ton amour et pour tes encouragements dans les moments les plus difficiles. Merci Zoïk et Thierno d'avoir aidé papa à sortir de sa tête et de lui avoir permit d'apprécier le bonheur simple des jeux d'enfants 


\section{Table of Contents}

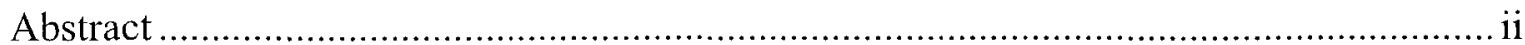

Acknowledgements - Remerciements..............................................................ii

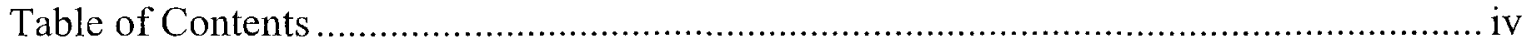

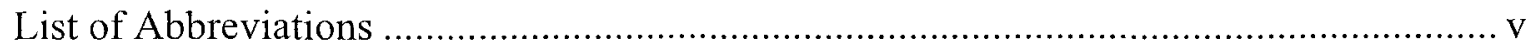

Chapter 1: Introduction .................................................................................... 1

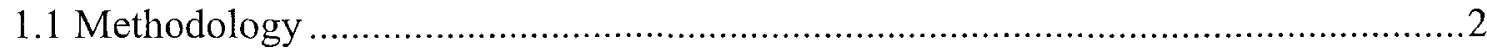

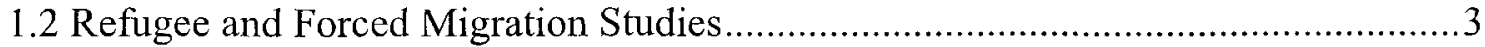

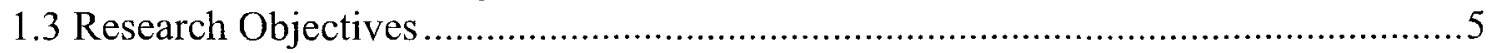

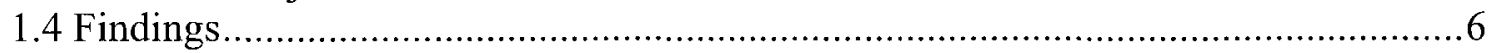

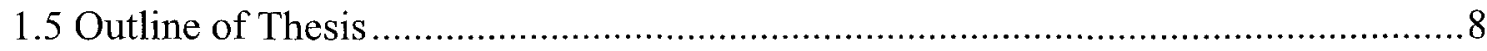

Chapter 2: Institutions, Texts and the Generous Concept of Work ............................ 11

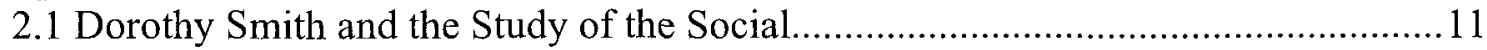

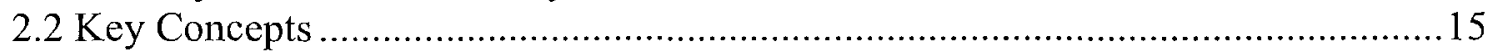

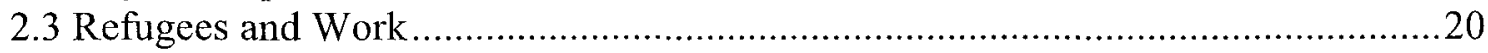

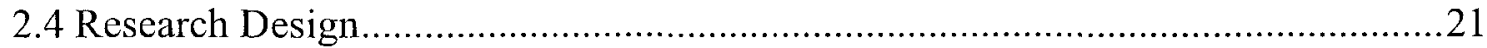

Chapter 3: Refugee Resettlement In Canada ....................................................... 29

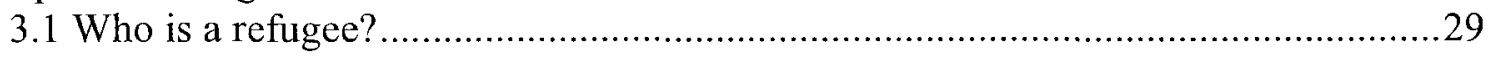

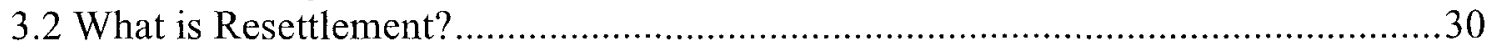

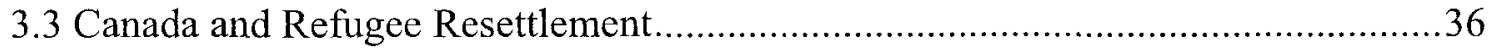

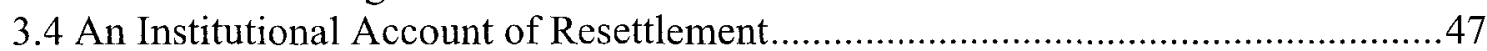

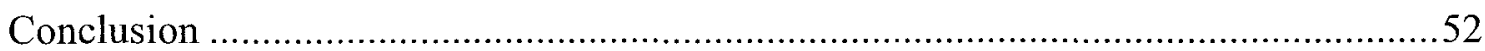

Chapter 4: The Long and Winding Road to Resettlement ........................................ 54

4.1 Interviews After Interviews: Resettlement and Remembering Work ....................55

4.2 "Les Années Passent": The Work of Waiting..................................................63

Conclusion ............................................................................................. 70

Chapter 5: Of Work and Texts: The Everyday Experience of Resettlement Workers .... 73

5.1 Locating the Work of Resettlement Workers .................................................... 74

5.2 Textualization and Regulatory Frames in Refugee Resettlement .........................75

5.3 How Resettlement Workers Think About Their Work: Institutional Capture.........78

5.4 The Work(s) of Resettlement Workers ...................................................... 80

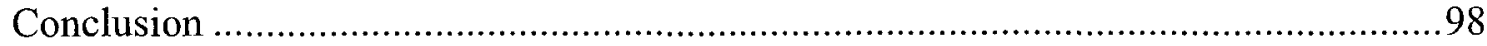

Chapter 6: Conclusion...................................................................................... 101

6.1 Finding \#1: Refugees are at work in the resettlement process.......................... 102

6.2 Finding \#2: Resettlement workers are caught between GARs and the State.........103

6.3 Finding \#3: Resettlement is an ongoing accomplishment ................................ 105

6.4 Areas for future research ...................................................................... 106

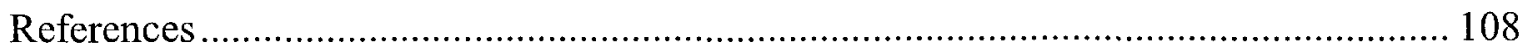

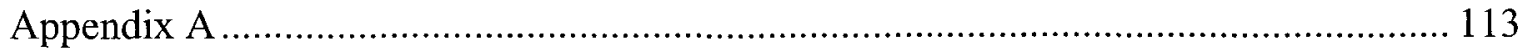

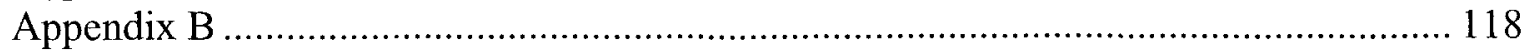




\section{List of Abbreviations}

APO Accueil-Parrainage Outaouais

CIC Citizenship and Immigration Canada

CLE Centre Local d'Emploi

ExCom Executive Committee of the Programme of the United Nation High

Commissioner for Refugees

GAR Government-Assisted Refugees

IOM International Organization for Migration

IRPA Immigration and Refugee Protection Act

LIQ Loi sur l'Immigration au Québec

MESS Ministère de l'Emploi et de la Solidarité Sociale

MICC Ministère de l'Immigration et des Communautées Culturelles

PANA Programme d'accompagnement des nouveaux arrivants

PAIR Programme d'accueil et d'installation des réfugiés

SSH Service de Sélection Humanitaire

TCRI Table de concertation des organismes au service des personnes réfugiées et immigrantes

UNHCR United Nations High Commissioner for Refugees 


\section{Chapter 1: Introduction}

Every year, between 7,000 and 8,000 Government-Assisted Refugees (GARs) are approved for resettlement in Canada. While the federal government assists about 6,000, some 2,000 are being taken in charge by the Québec government. GARs are underrepresented in the literature on refugee protection in Canada, possibly because they arrive in Canada with permanent resident status, in contrast to the thousands of individuals who arrive in Canada every year and claim asylum.

This thesis stems from a previous study conducted in Sherbrooke, Québec that looked at refugee women's experiences of resettlement. In contrast to my understanding of refugees as essentially passive in the resettlement process I realized how my informants had been active in the resettlement process. In the present thesis I wanted to explore this question by asking: how is refugee resettlement organized? What does resettlement entail on the part of refugees? What do refugees actually do as they go through the resettlement process? Moreover, my previous research had taught me how community organizations had played a major role in the refugees' arrival and integration in Québec. Consequently, a key objective of this thesis became to examine how resettlement is organized at the local level. What do resettlement workers do? How do they welcome and integrate refugees in their new city?

Starting from the experience of GARs and resettlement workers in the city of Gatineau, Québec, this thesis investigates the institutional organization of refugee resettlement. In contrast to an understanding of resettlement as a bureaucratic function to which refugees and resettlement workers are subjected, this thesis highlights the active 
role that GARs and resettlement workers themselves play in the resettlement process. It thus adds to the existing literature on resettlement by providing a new approach that does not regard refugees merely as recipients of resettlement but also acknowledges their necessary participation in the process. This thesis also sheds light on the work of resettlement workers in a way that accounts for the various tasks they performed on a daily basis but that are rendered invisible by the institutional organization of refugee resettlement.

\subsection{Methodology}

This thesis draws on the methodological and theoretical insights of Dorothy Smith (1987, 1990a, 1999b, 2005, 2006) and of Institutional Ethnography (IE). IE is a method of inquiry that begins in the everyday world of people's lives and how they participate in institutional relations. IE's "modest proposal is to work from what people are doing or what they can tell us about what they and others do and to find out how the forms of coordinating their activities 'produce' institutional processes, as they actually work" (Smith, 2005, p. 60). An important theoretical contribution of Smith is the 'generous concept of work' that incorporates not only paid work but also all activities that (re)produce and sustain social life. In this thesis this extended notion of work is used in order to highlight the active participation of my informants in the resettlement process. This thesis draws on interviews conducted in Gatineau, Québec with GARs $(n=4)$ and resettlement workers $(n=5)$ as well as on fieldwork performed at Accueil-Parrainage Outaouais (APO) between April and June 2011. The methodology used for this thesis as well as the design of the research on which this study is based are further discussed in Chapter 2. 


\subsection{Refugee and Forced Migration Studies}

This thesis seeks to make an original sociological contribution to the broad field of refugee and forced migration studies. This field of study emerged out of the aftermath of WWII when millions of displaced people found themselves in Europe and elsewhere. From that moment on, refugees have been of great international concern and the creation of the Office of the United Nations High Commissioner for Refugees (UNHCR) is a tangible expression of such concern. UNHCR was created in 1950 and remains to this day "the only global organization with a specific mandate to ensure the protection of refugees and to find solutions to their plight" (Loescher, Betts, \& Milner, 2008, p. 73). While there were studies that addressed refugee issues prior to this era, refugee studies as a coherent and organized field of study emerged during the late 1940s (Black, 2001). 'Refugee studies' continued to grow during the Cold War but it really experienced a dramatic expansion in the 1980s and the 1990s in part because of the arrival, in Western countries, of 'new asylum seekers' from the global South and because of the end of the Cold War (Chimni, 1998). Today, the field of 'refugee studies' continues to evolve and its blending with 'Forced Migration Studies' is an indication of this evolution. ${ }^{1}$

The academic literature on refugees today is rich and covers a vast array of subjects analyzed through the prism of many different disciplines, such as political science, sociology, anthropology, legal studies, geography, philosophy, international relations, literature, and psychology. But as Black (2001) points out, the "development of refugee studies has always been intimately connected with policy developments" (p.58). As such, and in addition to many works from anthropology that considers dynamics and

\footnotetext{
${ }^{1}$ For a discussion on the shift from refugee studies to forced migration studies and its implications see Hathaway (2007) and Chimni (2009).
} 
perspectives of individual refugee populations (e.g. Malkki, 1995), a growing focus of the literature on refugees has been to address refugees from the standpoint of States and other institutions and has attempted to find 'solutions' to various aspects of the 'refugee problem' (Nyers, 2006).

Some have critiqued this tendency in refugee studies. Dobson (2004), for instance, has argued that the international law and policy framework of analysis puts too much emphasis on "those who make the laws and implement them" (p.333). Taking a phenomenological perspective on refugee's life, Dobson developed the concept of 'refugeeness' in order to describe "how refugees in exile are the source of hybrid culture, founded existentially, through ontologically valued choices, which give rise to different ways of Being” (pp. 23-24). Dobson thus focuses on refugee's subjectivities in order to show, how, from refugeeness (i.e. experience of exile), hybrid culture emerges.

In his invitation to 'rethink refugees', Peter Nyers (2006) also invites us to put refugees at the centre of our analysis, but in a different way. Drawing on the work of Foucault, Agamben and Arendt, he develops a 'bio-political critique of humanitarianism' and urges us to 'rethink' refugees as political actors. As he puts it, "[r]efugees are not supposed to be political agents - that is the prerogative of citizenship. And yet, refugees are everywhere demonstrating political agency" (p. xvii). Nyers' contribution challenges the prevailing representation of refugees. As he argues, the "visibility, agency, and rational speech of the citizen is lacking in the prevailing representations of the refugees. Instead, qualities of invisibility, voicelessness, and victimage are allocated with the effect of effacing the political subjectivity of the refugee" (p. xv).

By bringing refugees on the front line in order to interrogate international politics as well as the complex discourse and practices of humanitarianism, Nyers (2006) makes an 
important transition: In contrast to studies on refugees that take the standpoint of the international refugee regime, Nyers uses refugees (and the 'limit case' of the refugeewarrior) as a point of departure in order to study the regime itself. Yet, he only does so conceptually and not from the perspective of actual people. In fact, he theorizes about forms of collective resistance, which he conceives as expression of political agency, in order to interrogate notions of state sovereignty and other political categories. The present thesis highlights the agency of refugees as they go through the resettlement process in a way that differs from Nyers' conception. Rather than focusing on forms of resistance, this thesis pays attention to the work that needs to be done by refugees so that resettlement can be accomplished. The notion of agency put forward in this thesis is therefore empirically grounded in the lived experiences of my informants and points to the ways in which these experiences are coordinating refugee resettlement.

\subsection{Research Objectives}

This thesis focuses on people's everyday experience in order to illuminate some corners of the institutional organization of resettlement. In fact this study looks at refugee resettlement in a way that, using the word of Moulin and Nyers (2007), "does not reproduce the dominant discourse of victimage about refugees and migrants that establishes them only as abject populations to be governed and controlled" (p. 371). As such it also challenges the dominant discourse on refugees by showing that GARs are always already 'at work' within the resettlement process.

What is proposed in this thesis is a way to put resettlement under the magnifying glass not as a reified entity but as a concrete, actual amalgamation of coordinated activities. This thesis asserts that IE can contribute to such a not yet explored dimension 
of the international refugee regime by paying attention to the lived experience of those whose lives are coordinated by resettlement and to explore the ways in which their everyday activities participate in this process. This study aims to empirically address the 'agency' of the refugee which has been either unrecognized or addressed almost exclusively at the theoretical level. It also seeks to generate a thick description of the everyday experience of those whose lives are shaped by the resettlement process so that we can see that refugees are more than just recipients of resettlement. This thesis also aims to highlight the work of the resettlement workers, which is almost invisible in the literature on resettlement. Finally this thesis is a first step in the mapping of the social relations of refugee resettlement. Such a mapping would allow people to situate themselves in the complex organization of refugee resettlement and expand their knowledge of how they participate in it. It is the contention of this thesis that by highlighting the interconnectedness of the institutional processes of refugee resettlement, new possibilities could emerge in terms of the coordination of resettlement across municipal, national and international boundaries as well as in terms of the recognition of the agency of refugees within these processes.

\subsection{Findings}

By taking the people-centered approach of IE, this thesis allows us to shed light on lived experiences that are made invisible by top-down treatments of refugee resettlement and to generate new knowledge about the ways in which refugee resettlement is institutionally organized.

For instance this thesis demonstrates that GARs are not passive recipients of resettlement but are actively engaged in the resettlement process in ways not fully 
captured in the literature on refugee resettlement in Canada. While Dobson argues that "[r]efugees and their destinies are largely dependent upon decisions made by people not in their presence - in the hidden corridor of power"(Dobson, 2004, p. 7), this thesis shows that refugees also exercise agency through their lived experience of resettlement. First it is argued that GARs have to engage in the difficult and emotionally challenging work of remembering traumatic events in order to be selected for resettlement. But while memory work is so vitally important in order to be deemed a credible refugee and selected for resettlement, the work of the refugee once in Gatineau involves the exact opposite move of forgetting all these events and names and facts - so as to mark the transition from a 'life in transit' to a 'new life'.

Second, this thesis argues that the waiting involved in the resettlement process is also a form of work that GARs need to be engaged in prior to their arrival in Gatineau. This type of work however is not recognized in the resettlement process and thus makes possible the problematic representation of the refugee as a passive recipient of resettlement services.

Also this study incorporates the everyday work of resettlement workers in the analysis and shows that there are obvious barriers and frustrations for these workers that arise from extraneous forces such as the housing market and the territorial dispersion of services in Gatineau. Following IE, this thesis also pays particular attention to the coordinating function of texts in the institutional organization of resettlement and shows how GARs' experience of resettlement is textually-mediated and how tensions between the textually coordinated work and the embodied work of resettlement workers arise. This thesis argues that resettlement workers are caught between the bureaucratic demands of the local organization of refugee resettlement and the actual needs of GARs. This study 
also shows that there is an important tension between resettlement workers' resources (financial, material, logistical) and the increasing resettlement workload. This situation is becoming unbearable for resettlement workers to the point where resettlement agencies are clearly advocating for more resources and threatening work-to-rule actions to achieve that end.

This thesis demonstrates that refugee resettlement is the result of the ongoing coordination of the work of refugees and other people situated across the institutional organization. It shows that in the case of refugees and resettlement workers, it is indeed an interaction of their respective activities and 'work' that produces something called 'resettlement.' This thesis argues that by starting from the lived experience of actual people we can access and study resettlement in a novel way that allows to connect various sites and practices that are usually examined in isolation. This new approach provides a more embodied knowledge of refugee resettlement that could serve as a tool for a range of actors, including resettlement workers, activists, and policy makers. For instance this study shows that there is a disconnect between the decisions made at the government level in terms of capacity for resettlement and the actual resources of community organization for the reception and integration of GARs. Such disconnects are addressed in the conclusion of this thesis where different types of research are discussed that could benefit from the insights of the present study.

\subsection{Outline of Thesis}

Chapter 2 first introduces the work of Dorothy E. Smith and her "sociology for people'. The theoretical foundation of institutional ethnography or what Smith calls her 'ontology of the social' is presented. IE is presented as a materialist approach that is 
sensitive to discursive practices. Key concepts such as 'relations of ruling', 'institution' and 'texts' are discussed. Particular attention is given to Smith's notion of 'work in a generous sense' and this concept is discussed in relation to refugee resettlement. Finally the design of the research on which this thesis is based is provided.

Chapter 3 serves as a background chapter and presents a brief history of refugee resettlement as a durable solution for refugees. Then a brief history of the Canadian refugee system and the particular status of the province of Québec are then presented with an emphasis on the resettlement of GARs. This chapter also discusses the tremendous gap in the literature in regards to GARs in Canada and in Québec. Finally, an overview of the resettlement process is provided.

Chapter 4 draws on Smith's 'extended notion of work' and uses accounts of GARs in order to highlight the active participation of refugees in the resettlement process and to demonstrate how, by starting from refugees' experience, we can investigate resettlement in a new and original way. This chapter first looks at the use of interviews in the resettlement process and argues that what it entails on the part of refugees is a form of work that is identified as 'remembering work'. This chapter then looks at waiting as another form of work that refugees perform within the resettlement process and argues that this is an integral, yet unrecognized, aspect of resettlement.

In Chapter 5 attention is paid to the work of resettlement workers in Gatineau and how their work coordinates and is coordinated by extra-local relations. The 'work' of resettlement worker is first situated as the 'end point' of resettlement. Then the textual aspect of resettlement is discussed. Then, various works, broadly conceived, are addressed. These include the difficult work of finding housing for GARs as well as the 'teaching work' performed by resettlement workers as they teach newly arrived refugees 
about 'how things work' in Gatineau. Another aspect of the resettlement workers' work is 'textual labour' and aims at the 'textual birth' of GARs.

Chapter 6 serves as a conclusion and discusses the implications of using IE for research on refugee resettlement and for policy. Areas of future research are finally presented. 


\section{Chapter 2: Institutions, Texts and the Generous Concept of Work Theoretical and Methodological Considerations}

In this chapter, I discuss the work of Canadian sociologist Dorothy E. Smith and Institutional Ethnography which guide my analysis of refugee resettlement in Gatineau, Québec. I first present Smith's 'ontology of the social' as well as some of her key concepts that are then usefully deployed in the study of refugee resettlement. This is followed by a discussion of my research design.

\subsection{Dorothy Smith and the Study of the Social}

Mainly known for her feminist critique of sociology and the development of a 'sociology for women' that was subsequently renamed a 'sociology for people' (Smith, 1987, 1990a, 1990b, 1999b, 2005, 2006), Smith had shown that the concepts of sociology create a disjuncture between how people experience the world and how concepts and theoretical schemes then inscribe those experiences into a dominant discourse. In order to develop her 'alternative sociology,' Smith drew on her own experience when she "combined work as an academic at the University of California at Berkeley with the single mothering of two children" (Smith, 1987, p.6). Smith's experience as an academic disposed her to a critical stance toward her experience as a single mother. At the same time, her experience as a single mother disposed her to call into question the doxic beliefs of the field of sociology. Smith's work also developed as she participated in the women's movement (Smith 1987) and through her involvement, as a professor, in higher education institutions.

Dorothy Smith's work focuses on the embodied experience of the social world. She developed what she calls an 'ontology of the social' that maintains the presence of 
the subject without making that subject the object of research. Drawing primarily on Marx and ethnomethodology, she "views the social world as being produced and brought into being through the social practices of people" (Frampton, Kinsman, Thompson, \& Tilleczek, 2006, p. 34). It is people, by their doings, who make the social 'happen'. From this perspective, the social is understood as an ongoing process and should not be reified. Smith (2005) uses the word 'ontology' to distinguish her theory from other forms of theorizing in what she calls 'mainstream sociology'. As she puts it:

Mainstream sociology imposes theoretical organization interpreting what people are actually doing and saying in a fashion that situates the knower outside the account and represents people as objects. When actor and action are theorized, both are abstracted from the ongoing historical process of the moment and what people are doing and bringing into being, and both are resituated in a discourse fully under sociological control. (p.53)

The type of theory that Smith calls for, on the contrary, is one that "provides a conceptual framework for selective attention to actualities such that the project of inquiry can proceed as discovery of and learning from actualities" (Smith, 2005, p.52). In the following paragraphs I will look at the five main claims of Smith's 'ontology of the social' that serves as the theoretical basis of institutional ethnography (IE).

1-Smith's ontological ground is in actual people's doings under definite material conditions.

Against the Idealism of German philosophy "which descends from heaven to earth", Marx and Engels (1978) proposed a philosophy which "ascend[s] from earth to heaven" (p. 154) i.e. a philosophy which has at its starting point "the real individuals themselves" (p.155). As they put it:

The premises from which we begin are not arbitrary ones, not dogmas, but real premises from which abstraction can only be made in the imagination. They are the real individuals, their activity and the material conditions under which they live, both those which they find already existing and those produced by their activity. (Marx, 1978b, p.149) 
This statement anchors Marx's philosophical project in a materialist conception of history that constitutes one of his major theoretical/methodological contributions. It is not consciousness that serve as the basis of philosophical investigation for Marx but "real, active men" working and creating the conditions for their existence in time and space.

For Smith (2005) this critique is more than a critique of idealism that gives primacy to ideas over practice, it is also "a critique of a method of reasoning about society and history that treats concepts as if they were agents" (p.54). IE is not a Marxist project per $s e$, but it does "take seriously Marx's scrupulous attention to the ontological grounding of the concepts and theories of social sciences" (Smith, 2005, p.57).

2- Focus on how people's doings are coordinated.

For Smith, the social is understood as people's doings as they are coordinated with those of others. As Smith (2005) argues, "Individuals are there; they are in their bodies; they are active; and what they're doing is coordinated with the doings of others. That is the four-part package that is foundational to the institutional ethnographic project" (p.59). What institutional ethnographers propose is to "work from what people are doing or what they can tell about what they and others do and to find out how the forms of coordinating their activities 'produce' institutional processes, as they actually work" (p.60). Social life is not chaotic, argues Campbell and Gregor (2008), "but is instead organized to happen as it does" (p.27).

\section{3- For Smith the social generates differences.}

By starting from actual people, IE starts from individuals who are unique and have their own perspectives. It is argued by Smith (2005) that "the social, as the concerting of people's doings, builds on and generates divergence of perspective and interest" (p.61). But IE is not interested in explaining or theorizing these differences, rather it aims at 
discovering the ways in which what people do coordinates and is coordinated by the doings of others. This alternative focus shows a fundamental difference between Smith and other theorists. Bourdieu's (1990) theory of practice, for instance, is exactly about providing an explanation for the differences (as well as the similarities) between social agents' actions. His conceptual toolkit (habitus, capital, field) aims at explaining people's practices in terms of taste, political opinion, leisure, etc. For Smith (2005), however, “what people are isn't the institutional ethnographer's business in this sense: she or he does not aim at explaining people's doings in terms of a theoretical system in which they must be accorded proper theoretical value" (p.61). The focus is always the coordination of people's activities.

\section{4- The social is always into motion.}

While 'mainstream sociology' has developed and worked with concepts such as order, patterns, and structures, i.e. "with concepts that reify the social as distinct states or determinants" (Smith, 2005, p.64), Smith sees the coordinating of people's activities as an ongoing process. For institutional ethnographers, "the world of people's activities and how they are coordinated among individuals is always in motion. Each moment of action is conditioned by what is historically given and reshapes the already given in moving into the future" (Smith, 2005, p.70). The notion of 'social structure' is being replaced by "an ongoing historically committed interplay of people's doings" (Smith, 2005, p.68). The social is 'accomplished' or 'produced' by the doings of people.

\section{5- Language coordinates people's subjectivities.}

For Smith, language is conceived as central to 'ruling relations' i.e. a combination of "state, corporate, professional and bureaucratic agencies in a web of relations through which ruling comes to be organized" (Frampton, et al., 2006, p. 37). As such language 
has to be brought into ethnographic investigation "just as any other local practices" (p.69). Like Voloshinov (1973), Smith thinks that language is a social act and not a preexisting structural phenomenon. Like any form of praxis, language is developed and performed socially i.e. with others. But language is a particular form of praxis that coordinates people's experiences (or subjectivities).

In sum, Smith's ontology of the social consists of a set of propositions about the world we live in that draws on previous theoretical work done by people like Marx, Garfinkel, and Voloshinov. This is perhaps the greatest paradox of Smith's work which denounces the primacy of theory in sociology by resorting to theory. This criticism has been formulated most clearly by Kevin Walby (2007) when he states that "although institutional ethnographers claim to be people-centered instead of theory-driven, Smith's ontology of the social determines the frame of institutional ethnographic discourse" (p. 1021). To this date, no one has provided a response to Walby's critique. Although it is not the purpose of this thesis to do so, I nonetheless want to say that if it is true that Smith's ontology of the social is a 'theory,' it is a different form of theory than that she is critiquing. ${ }^{2}$

\subsection{Key Concepts}

\section{What is an institution?}

In Smith's work, institution does not refer to a particular type of organization. Instead, an institution is viewed as a "vast complex of coordinated and intersecting workprocesses taking place in multiple sites" (Devault and McCoy, 2006, p.17). For example,

\footnotetext{
${ }^{2}$ I am currently working on formulating a response to Walby. Drawing on Fairfield's (2000) notion of "practice-immanent theorizing" I argue that Smith's 'theory' is one that, keeping with her feminism, is rooted in praxis and, in that respect, differs from the type of theories she says to avoid in IE which are to be understood as a form of what Aristotle called theoria.
} 
what an institutional ethnographer sees when he or she looks at the institution of health care, is a "vast nexus of coordinated work-processes and courses of actions - in sites as diverse as hospitals, homes, doctor's offices, community clinics, elementary schools, workplaces, pharmacies, pharmaceutical companies, advertising agencies, insurance companies, government ministries and department, mass-media, and medical and nursing schools" (DeVault \& McCoy, 2006, p. 17). Similarly we can conceive of refugee resettlement as an institution i.e. as a vast complex of coordinated activities that take place in various locations including camps, offices, airports, hotels, etc. The activities are mediated by what Smith calls the relations of ruling.

\section{Relations of ruling}

A distinctive form of textually based power arose, according to Smith, out of the development of capitalism into its contemporary form. While the social conditions of the $19^{\text {th }}$ century allowed Marx to conceptualize 'consciousness' as an attribute of individuals (Marx \& Engels, 1978), today's social conditions call for a reconceptualization of 'consciousness' "as the working of objectifying organization and relations mediated by texts and computer technologies" (Smith, 1999b, pp. 78-79). Dorothy Smith (1999a) defines ruling relations as an:

...internally coordinated complex of administrative, managerial, professional, and discursive organization that regulates, organizes, governs, and otherwise controls our societies. [...] It is a mode of organizing society that is truly new for it is organized in abstraction from the local settings, extra-locally, and its textually mediated character is essential [...] and characteristic. (p.49)

The term 'ruling' however can sometimes be misleading because although ruling relations are a form of organized power, they are not always relations of domination. In fact the textual production of ruling also produces agency i.e. the "textually specified 
capacities to control and mobilize the work of others" (Smith, 2005, p. 227). Smith sometimes uses the expression "coordinating relations" to address this ambiguity.

As organizers of experience, ruling relations are conceptually akin to Foucault's notion of discourse. However, Smith put a lot more emphasis on the materiality of texts than Foucault does. In fact the central feature of ruling practices in contemporary society is, according to Smith, its reliance on texts.

\section{Texts as Coordinators}

In so-called knowledge economies such as ours, argues Deveau (2008), "textbased forms of knowledge and discursive organization play a central role in shaping people's everyday/everynight lives" (p.9). Texts produce the stability and replicability of organization or institution and can take many forms: print, electronic, and even video (Walby, 2005) or photographs (McCoy, 1995). It is the materiality of texts that bestow upon them the capacity to coordinate people's doings across different sites by "being able to turn up in identical form wherever the reader, hearer, watcher may be in her or his bodily being" (Smith, 2005, p.228). At the level of institutions, texts are forms, memos, plans, audits, charts, etc. that coordinate the work of people.

Texts for Smith must be apprehended 'in motion'. In institutions, texts are not 'static'; they are a moment in a sequence of coordinated activities and therefore must be analyzed in action. Texts are activated by people and this activation coordinates with someone else's doings.

The emphasis on texts as coordinator rather than 'determinator' is important because it highlights the dialogic dimension of the work-text-work sequencing that is characteristic of contemporary institutional organization. In fact, texts in themselves do 
not 'possess' their coordinating ability; they rather depend on the activities of actual people to realize their coordinating function.

\section{Work in a Generous Sense}

In institutional ethnography work extends beyond commonsensical notions of paid employment or (as explained below) unpaid labour and refers to "anything done by people that takes time and efforts, that they mean to do, that is done under definite conditions and with whatever means and tools, and that they have to think about" (Smith, 2005, pp. 151-152). In order to develop this 'generous conception of work', Smith drew on the thinking of a feminist group called Wages for Housewives, that originated in Italy, which believed that housewives were doing unpaid work that was sustaining the paid work in society and, by the same token, capitalism. Smith expanded the notion of work to include not only the unpaid work of housewives but also all the activities that are not recognized as work but that are playing an active role in sustaining the organization of social life and its institutions. Smith (2005) gives a good example of her conception of work by describing a passage from Nona Glazer's book entitled Women's paid and unpaid labour: The work transfer in health care and retailing. She notes:

Nona Glazer has drawn attention to a general transfer of work in contemporary society from paid to unpaid work, which is also a shift of time and costs. One example she gives is the work done by customers in a contemporary grocery store. She contrasts it with a period when customers did not walk up and down the aisle picking out what they wanted to buy, putting them in a basket or cart, and moving them to the checkout. Everything was done by the sales clerk. You could even go into the corner store in the morning, leave your list of groceries, and it would be delivered to your house while you went to work. $[\ldots]$ In any grocery store we go into now, the work of finding the stuff on the shelves and toting it down to the checkouts is the customer's work. It's no longer the work of the sales people and other staff to go and find things for you. You tote it out to the car; nobody delivers it to your door. You transport it home, and that's work, too (and the cost of transportation is yours). These activities take time. In the days when you thought out a list in advance, you took it down to the grocery store and someone would deliver your box of groceries to your door; it was the store's time - paid time, not unpaid time. (p.154) 
Smith thinks of work processes as the fundamental grounding of not only the actual economic system but of social life as a whole. The generous concept of work directs the attention of the research to all these activities that are not usually recognized as work. It could be work done by paid employees that is outside their job description as well as activities conducted by unpaid people that are not conceived as sustaining a particular organization of social relations but that actually do. The intent of this concept is to move beyond ideological definitions of work and workers in order to explore how institutions and the lives they coordinate are organized. Reflecting on the feminist roots of institutional ethnography and on the generous concept of work, Devault (2008) states that Smith

...saw that the control and appropriation of work happened, in part, through organizational strategies that highlight and support some kinds of work while leaving other tasks unacknowledged, to be done without recognition, support, or any collective responsibility. By contrast, the generous concept of work used by institutional ethnographers directs the researcher to recover the work that is actually being done and to provide a more complete accounting of social organization - or, in colloquial terms, to show how things are "put together. (p.7)

This focus on 'work' locates researchers' investigation into the everyday and mundane aspects of people's lives. This notion of work anchors investigation in material conditions and means. For instance, Alison Griffith and Dorothy Smith (2005) used the notion of 'mothering work' to illustrate that schools depends on the expected carrying out of various activities involved in mothering. In short, they have argued that "teachers cannot teach unless mothers get children to school on time, and the kind of teaching they can do is shaped by what children have already learned, a product at least in part of parental efforts that may vary considerably from one neighborhood to another" (Devault, 2008, p. 8). 
In their study that explored the work undertaken by people living with HIV/AIDS (PHAs) to look after their health, Mykhalovskiy and McCoy (2002) designed the concept of 'healthwork'. This conceptual device allowed them to focus on the various things that PHAs do in relation to their health condition without presupposing what these things were: "[h]ealthwork, as we used it, located our research within a genuine investigative mode of inquiry. It operated as an empirically empty term, one that waited to be filled as PHAs told us about their practice and their experience"(p.24). These two completely different expressions of the generous notion of work nonetheless share a specific function: that of anchoring the research in people's everyday lives.

\subsection{Refugees and Work}

Drawing on Smith's extended notion of work (Smith, 1987, 2005) and more precisely on Mykhalovskiy and McCoy's (2002) notion of 'healthwork,' I started to think of refugee resettlement as involving 'work' not only on the part of the employees of the different agencies, organizations and government ministries involved but also on the part of the actual subjects of this process i.e. the refugees themselves. Using the generous notion of 'work' allows me to direct my attention to what people 'do' throughout the resettlement process and to "fill it" with experiential accounts. The notion of work used in this study refers to the actual doings of both refugees (Chapter 3) and resettlement workers (Chapter 4) throughout the long and complex process of resettlement in

Gatineau. Through an attentive look at the work performed by refugees we can start to see how what they do connects with what the other parties involved in resettlement also do and thus extend our research to the ways in which these various doings are put together so as to produce resettlement. 


\subsection{Research Design}

Consistent with IE as an approach to sociological inquiry, this study does not attempt to test any hypothesis. Rather it aims at exploring "the work activities through which people are themselves involved in producing the world they experience in daily life" (Grahame, 2004, p.185). The problematic of this research is refugee resettlement in Gatineau, Québec. This study investigates the ways in which the social organization of refugee resettlement in Gatineau is 'put together' by generating a thick description of the everyday experience of both GARs and resettlement workers.

In the first place, this study presents and describes the 'work' performed by refugees before they come to Canada as GARs of the Convention Refugee Class. Then I turn my attention to the 'work' done by resettlement workers from the reception of GARs to their resettlement into their first apartment in Gatineau. The objective is to expand our knowledge of what is involved on the part of both GARs and resettlement workers throughout the resettlement process and to generate questions that can serve as the basis for further research in the area.

The research on which this thesis is based was conducted in three moments. The first moment consisted in interviewing GARs living in Gatineau on their experience of resettlement with a focus on the events that occurred between their arrival in their country of first asylum and the moment they left to come to Canada. The second moment consisted in interviewing people involved in the local provision of resettlement services to GARs in Gatineau on their everyday work. The third moment of research was to follow a resettlement worker as he resettled a family. 
Selection of research participants.

In Gatineau, it is Accueil-Parrainage Outaouais (APO) that provides resettlement services to GARs on behalf of the government of Québec. In order to gain access to GARs as well as resettlement workers, I contacted the director of APO and introduced my project to him. He agreed to help me in my research by distributing my letter of information (Appendix A) about the research project to APO staff members as well as to GARs. The participants were thus selected through a combination of purposive sampling and snowball sampling and I was able to find five GARs who were willing to participate in my research. The GARs participants were chosen according to two main criteria: (1) they had to speak either French or English in order to avoid the use of an interpreter during the interview process. In that way certain ethical concerns about confidentiality were avoided; (2) they had to be GARs of the Convention Refugee Abroad Class so that their trajectory would necessarily involve UNHCR. One of the GARs interviewed, however, had been resettled to Canada from Russia and had a very peculiar itinerary of resettlement that could not be addressed in this thesis. It was thus decided that his account would not be used and that this research would be based on the accounts of four GARs.

All four GARs participants are from Sub-Saharan Africa; two are originally from Togo (one had found refuge in Benin and the other in Ghana). One is from CongoBrazzaville (and had fled to the Democratic Republic of the Congo) and the other is originally from the Democratic Republic of the Congo and had found refuge in Kenya. Since my intention was never to produce a representative sample but rather to open a new area of inquiry, I did not seek to interview people coming from the same country of origin. However after having interviewed my first two GARs informants, I decided to select future participants by choosing those coming from Sub-Saharan Africa. 
The reason for this was simple: my discussions with the APO staff at the beginning of my research suggested that the people coming from this region were usually sicker and poorer then most other GARs resettling in Gatineau and that because of that, the APO staff members' work was usually more difficult to accomplish when their clients were coming from Sub-Saharan Africa than from other refugee-producing regions of the world. This situation constituted a problematic that this research could focus on. It is also true that I had found similarities in the first two interviews about the pre-resettlement experience and wanted to get a range of similar experiences that would generate a coherent point of entry into the organization of refugee resettlement both at the local and extra-local levels.

As for the non-GARs participants, the APO staff (i.e. 5 out of 6 of its members) as well as its director agreed to be interviewed. The staff members work as resettlement workers and are therefore responsible for the initial resettlement of GARs in Gatineau. I was also granted permission to interview one MICC staff member working in Gatineau.

It is important to note here that this study does not claim that we can generalize from the experience of the few people interviewed to the experience of all GARs and resettlement workers in Québec, Canada, or elsewhere. As DeVault and McCoy (2006) argue,

[t]he researcher's purpose in an institutional ethnography is not to generalize about the group of people interviewed, but to find and describe social processes that have generalizing effects. Thus, interviewees located somewhat differently are understood to be subject, in various ways, to discursive and organizational processes that shape their activities. (p.18)

Remember that IE does not study people per se; rather, it studies institutions through people's experiences of them. Ruling relations, however, do have generalizing effects that produce generalizations at the local level. As Peter R. Graham (2004) argues, 
"Institutional processes transform local, concrete and particular action into 'standard forms of organizational action'; in this way, local activities take on generalized form"

(p.184). The experience of the individual whose daily activities are shaped by institutional processes, thus presents itself as an "entry point into the actual workings of those institutions which produce the generalized and abstract character of contemporary society" (Grahame, 2004, p. 185). The goal of this research is thus not to generalize from the particular but rather to look at how the particular is the locus of the generalizing effects of institutional processes. If it is true that the range of experiences studied is relatively limited, it remains that since the object of study is the resettlement process itself (and not the informants' experiences) we can nonetheless make certain claims about the outcome of its institutional organization.

\section{Interviews}

In IE, interviews need not be standardized since the researcher seeks to take the standpoint of the interviewee and learn from him or her. Each interview offers a perspective for investigation (DeVault \& McCoy, 2006). The first step of my research thus consists in conducting semi-structured open-ended interviews with my informants $(\mathrm{n}=11)$. The interviews were held between April and June 2011 and lasted between 55 minutes and two hours. All interviews were conducted in an office at APO except for the one with the MICC staff member which was conducted at the MICC office in Gatineau. This was done so that in the event that a GAR participant needed special care during an interview, an APO staff member would have been there to help. This, however, did not happen. One of my non-GAR informants was interviewed twice because we had to internupt the first interview due to time constraints. All the other informants were 
interviewed once. All interviews except one were recorded on an electronic recording device. In fact one of my non-GAR informants preferred not to be recorded.

Before the interview, the research participants signed an informed consent form (Appendix B) that outlined the purpose of the research, the nature of their participation, and the possible risks associated with it. Since I could not guaranteed total anonymity to my informants because of the nature of the sampling process, the form mentioned that identifying information would not be made available to anyone who is not directly involved in the study, thus ensuring confidentiality.

In order to avoid as much as possible the potential triggering of difficult emotional reactions, no questions were asked to GARs about what happened prior to their exile. No questions were asked regarding issues such as war, persecution, torture, death, and deprivation. Instead, the interview was oriented to the institutional process they went through in order to came to Canada as refugees and resettle in Gatineau. It was also stipulated in the consent form that if they wanted to talk about their traumatic experiences it was their choice and that they had to be aware that it might trigger difficult emotional reactions.

All interviewees were able to suspend or end the interview whenever they wanted without having to justify themselves.

My informants were first asked "can you please teach me about your experience in relation to refugee resettlement?" My interviewing was then informed by the generous notion of work described above as well as a particular attention to texts.

\section{Shadowing}

The third moment of the research phase was to shadow a resettlement worker as he works on an actual resettlement case. In fact I did not specifically ask about following 
a resettlement worker in the field but was rather offered the possibility to do so. One of the resettlement workers I interviewed asked me at the end of the interview if I would like to see 'how it happens for real'. He was the one to whom the next case was going to be attributed and told me that as soon as another GAR was resettled in Gatineau I was going to follow him.

On the night between June $20^{\text {th }}$ and $21^{\text {st }}$, the Bembas ${ }^{3}$ arrived in Gatineau. The next morning I followed the resettlement worker and introduced myself to the Bembas and specifically stated that I was a researcher and not an APO staff member. I ask them their permission to follow the resettlement worker responsible for their case. They agreed and then Mr. Bemba, the head of the family, asked me if I wanted to interview him as well for my research, which I did.

From June 21 st to June $28^{\text {th }}$ I followed the resettlement worker responsible for the case and spent considerable time with the Bembas by the same token. I took notes of what I saw and asked an incredible number of questions. This allowed me to witness an actual example of how resettlement in Gatineau happens. Also informed by the generous notion of work and of the coordinating function of texts, my observations were oriented towards the actual activities in which both the resettlement worker and the Bembas were engaged in through the resettlement process as well as the presence of texts. As will be seen in Chapter 5, resettlement is highly rich in both 'works' and textual coordination. In fact it was possible, within the frame of this thesis, to address but a fraction of what is actually going on in the field.

Finally, it has to be mentioned that I spent a considerable amount of time talking to people and observing their work at APO as I hung around reading activity reports or

\footnotetext{
${ }^{3}$ All the names of my informants are pseudonyms.
} 
waiting between two interviews. These moments were important for the research not only in terms of creating rapport with people but also in terms of getting a sense of how things work. This process of 'hanging around' is also consistent with IE as a research strategy (see for instance Diamond, 1995; Ng, 1996).

An analytical strategy

Institutional Ethnography is a method of inquiry that starts from actual people and explores the ways in which their experiences are organized and how they participate in that organization. The notion of participation here refers to the fact that institutions only exist through people's ongoing concerted activities. As such,

...IE explores the social relations organizing institutions as people participate in them and from their perspectives. People are the expert practitioners of their own lives, and the ethnographer's work is to learn from them, to assemble what is learned from different perspectives, and to investigate how their activities are coordinated. It aims to go beyond what people know to find out how what they are doing is connected with other's doing in ways they cannot see. (Smith, 2005, p. 225)

IE takes people's actual experiences of the world as its starting point but refuses to 'interpret' or 'theorize' these experiences. In fact the object of study of an IE is not people's experiences per se but rather how these experiences are socially organized so that they happen as they do. What is being theorized and interpreted in IE are therefore the institutional arrangements that allow for people's experiences.

The focus of research in IE is on social relations that coordinate people's everyday lives. As Grahame (2004) puts it, an institutional ethnographer works at "discovering the ways in which a localized work organization operates as part of a broader set of social relations which link multiple sites of human activity" (p.185). In that respect, Smith expanded the feminist notion that the personal is political by positing the everyday world as an entry point for investigating the ruling relations that are not simply located in particular relations but extend to broader social locations. 
Institutions, however, cannot be studied in totality. What IE is aiming at, is to "explore particular corners in an institutional complex in ways that make visible their points of connection with other sites and courses of actions" (Devault and McCoy, 2006, p.17). In the present study I explore two particular corners of refugee resettlement. One is the resettlement process abroad as my GARs informants experienced it and the second is the local provision of resettlement services as the resettlement workers I interviewed and whose work I observed experience it everyday. 


\section{Chapter 3: Refugee Resettlement In Canada}

Refugee resettlement is a transnational process that happens in many different sites and involves the work of many people. In order to contextualize the particular corners of the resettlement process this thesis addresses, this chapter provides an overview of what resettlement is and serves as the background of the research conducted on the resettlement of GARs in Gatineau, Québec. First, the definition of who is a refugee is described so to avoid any possible ambiguity regarding its meaning in the present thesis. Second, this chapter presents an overview of resettlement as a durable solution for refugees. A definition and a brief history of resettlement as well as the actual criteria used by the UNHCR to refer refugees to resettlement countries are discussed in light of the present state of resettlement. Third, the Canadian refugee system, with a focus on resettlement of GARs is presented. A brief history of resettlement in Canada and of the legislative changes that pertain to refugee resettlement as well as a review of the small existing literature on GARs in Canada is provided. Finally, this chapter presents the 'formal' process through which GARs are typically resettled in Gatineau, Québec. This institutional account of resettlement provides an archetype of resettlement against which the findings of this research are being discussed.

\subsection{Who is a refugee?}

By the end of 2010 , there were 43.7 million forcibly displaced people worldwide, the highest number in 15 years. Of these, 15.4 million were refugees. ${ }^{4}$ The most universal definition of the term "refugee", and the definition used in this thesis, is found in Article

\footnotetext{
${ }^{4} 10.55$ million refugees are recognized under UNHCR's mandate and 4.82 million Palestinian refugees registered with UNRWA. The overall figure also includes 837,500 asylum-seekers and 27.5 million internally displaced persons. (UNHCR, 2011a, p. 3). It should be noted that these numbers do not include people displaced by disasters or development projetcs.
} 
(hereinafter, UN Convention) that defines a refugee as:

[a] person who owing to a well-founded fear of being persecuted for reasons of race, religion, nationality, membership of a particular social group or political opinion, is outside the country of his nationality and is unable or, owing to such fear, is unwilling to avail himself of the protection of that country; or who, not having a nationality and being outside the country of his former habitual residence as a result of such events, is unable or, owing to such fear, is unwilling to return to it.

Since its publication, this definition has been analyzed, contested and critiqued

from all sides and has generated many debates. However, it is not the purpose of the present thesis to address these issues. The reason this definition is uncritically used in this thesis is because it acts as a regulatory 'text' that coordinates the resettlement process. In fact, the UN Convention is among the most important 'texts' in the textual hierarchy of refugee resettlement. It is used not only by UNHCR in order to determine refugee status but it has been incorporated in the Canadian legal framework pertaining to refugees as well.

\subsection{What is Resettlement?}

The UNHCR Resettlement Handbook defines resettlement as follows:

Resettlement involves the selection and transfer of refugees from a State in which they have sought protection to a third State which has agreed to admit them - as refugees with permanent residence status. The status provided should ensure protection against refoulement and provides a resettled refugee and his/her family or dependents with access to civil, political, economic, social and cultural rights similar to those enjoyed by nationals. It should also carry with it the opportunity to eventually become a naturalized citizen of the resettlement country. (UNHCR, 2004, p. I/2)

Resettlement is an instrument of refugee protection and aims at meeting the needs of refugees "whose life, liberty, safety, health or other fundamental human rights are at risk in the country where they sought refuge" (UNHCR $2004 \mathrm{VI} / 1$ ). It is also considered a durable solution for refugees alongside voluntary repatriation and local integration. Finally, resettlement "can be a tangible expression of international solidarity and a 
responsibility sharing mechanism, allowing States to help share each other's burdens, and reduce problems impacting the country of first asylum" (UNHCR, 2004, p. I/1).

\section{Brief history of resettlement}

As a durable solution to various refugee crises, resettlement has been used on many occasions throughout modern history. At the end of WWII resettlement was promoted as the durable solution par excellence:

Motivated by the objective of ensuring peace and stability in Europe, and concerned with the prospects of returning displaced persons to Communist regimes, overseas resettlement was identified by the Western powers as the preferable solution for refugees remaining after World War II. By 1950, over a million people were resettled, primarily to countries outside Europe. (Milner, 2005, p. 520)

From the period that followed WWII until the mid 1980s, which corresponds roughly to the Cold War era, resettlement expanded and continued to be seen as the most appropriate solution for refugees. This can be explained in part by the fact that "Western governments, led by the United States, used resettlement not only as a tool of protection for those in need, but also as a means of highlighting the failures of communist regimes" (Milner, 2009, p. 49). During this period, resettlement was highly driven by the Western states' foreign policies and was used for particular groups of refugees, like those fleeing Eastern Europe or Indochina (Loescher \& Scanlan, 1986).

The end of the Cold War marked a shift in the prioritization of other durable solutions over resettlement. From 1985 on, voluntary repatriation came to be regarded as the preferable solutions to the refugee problem (Chimni, 1998). Today, there seems to be a hierarchy of preference among institutional actors regarding durable solutions and resettlement is usually considered the durable solution of last resort:

The decision to resettle a refugee is normally made only in the absence of other options, such as voluntary repatriation or integration in the first country of refuge, or where resettlement is seen as the best durable solution for the individual or refugee groups in question. It becomes a priority when there is no other way to guarantee the legal or 
physical security of the person concerned. (UNHCR, 2004, p. I/3)

According to Milner (2005), Chimni's "characterization of the 'end of the era of

resettlement' proved, however, to be an exaggeration" (p.520). As he argues,

Significant developments have occurred in the area of resettlement since the mid 1990s. In June 1995, a Working Group on Resettlement was established to discuss annual resettlement quotas and criteria. Annual Tripartite Consultations on Resettlement (ATC), are now held with governments, Non-Governmental Organizations (NGO) and UNHCR, and have proven to be a valuable forum for enhancing partnerships, developing joint strategies for addressing resettlement needs, information sharing, and the development of a more harmonized approach to resettlement. (p.521)

Although political factors still influence the use and the nature of resettlement to a certain extent, "resettlement priorities and procedures are becoming increasingly harmonized as resettlement countries see the increasing value of cooperation in the resettlement process" (Milner, 2005, p. 522). The UNHCR Resettlement Handbook that was published in 1997 (and revised for the last time in 2004 ${ }^{5}$ ) is an example of such harmonization efforts. It provides a general set of criteria and procedures as well as a five-step process of resettlement, as outlined below.

\section{Criteria for resettlement}

The UNHCR (2004) defines the eight criteria on which a resettlement submission

can be made as follows:

1. Legal and physical protection needs, when a refugee's situation meets one or more of the following conditions: (1) Immediate or long-term threat of refoulement to the country of origin or expulsion to another country from where the refugee may be refouled. (2) Threat of arbitrary arrest, detention or imprisonment. (3) Threat to physical safety or human rights in the country of refuge, rendering asylum untenable. (p. IV/5)

2. Survivors of Violence or Torture, when the required coordinated medical care, counseling and other types of special assistance are not available in the country of first asylum in particular when they suffer from physical and/or serious psychological problems. (p. IV/8)

3. Medical Needs, when the following conditions are met:

o The health condition is life-threatening without proper treatment; or

o There is a risk of irreversible loss of functions; or

o The health condition presents a significant obstacle to leading a normal life and achieving selfsufficiency;

\footnotetext{
${ }^{5}$ A new version is about to be published.
} 
and

o Adequate treatment is not available in the country of asylum, due to lack of medical facilities and expertise;

o Adequate treatment cannot be ensured through temporary medical evacuation1;

$o$ In the case of a disability, the situation in the country of asylum prevents the individual from becoming well adjusted and from functioning at a satisfactory level;

and

o There is a favorable prognosis that treatment and/or residence in the country of resettlement would successfully address the health problem and, if possible, given the expected state of health after treatment/relocation, enable the individual to gain partial or total independence; or o The particular situation in the country of asylum is the reason for, or significantly worsens, the health condition;

and

o It is the expressed wish of the individual, after having been counseled in particular with regard to the social, cultural and psychological adaptation required in a new community. (p. IV/10)

4. Women-at-risk, when refugee woman or girl faces precarious security or physical protection threats as a result of her sex. When she has specific needs arising from past persecution and/or traumatization. When she faces circumstances of severe hardship resulting in exposure to exploitation and abuse, rendering asylum untenable. When there has been a change in the social norms, customs, laws and values resulting in the suspension of or deviation from traditional protection and conflict resolution mechanisms and the lack of alternative systems of support and protection. Consideration should be given to resettlement under such circumstances if this places the refugee woman or girl at such risk that it renders asylum untenable. (p. IV/20)

5. Family reunification, when resettlement can preserve or restore the basic dignity of a refugee's life through the reunification of his/her family which has been separated as a result of their persecution or flight. (p. IV/23)

6. Children and Adolescents, where a 'best-interest determination' for unaccompanied or separated minors in a refugee situation determines that resettlement is the best solution for the child. It is generally held that resettlement of unaccompanied minors should only be considered on a case-by-case examination where other solutions, such as tracing for other family members or local adoption, are not appropriate. (Milner, 2005)

7. Older refugees, when elders are particularly vulnerable when confronted with the causes and effects of becoming a refugee, and for whom resettlement, typically to be reunited with other family members constitutes a viable solution. (p. IV/51)

8. Resettlement for refugees without Local Integration Prospects, when refugees do not have an opportunity to establish themselves in their country of refuge in a manner appropriate to their cultural, social, religious or educational backgrounds. (p. IV/52)

These resettlement criteria, which are generally used by individual resettlement

countries as well, have to be assessed by UNHCR staff members in a dynamic way: "in

many cases, criteria may overlap and cumulative effects should be considered and

emphasized in a resettlement submission" (UNHCR, 2004, p. IV/4). Moreover, these

criteria do not have equal weight in relation to the processing of resettlement submissions.

In fact, when we look at UNHCR submissions of cases to resettlement countries for the 
year 2010 (UNHCR, 2011b), we can see that there is a significant disparity between the criteria. While 'Legal \& physical protection needs' was used in $40 \%$ of the submissions and 'Lack of integration prospects' in $28 \%$ of them, 'Children and adolescents' represented less than $1 \%$ of all the UNHCR submissions for resettlement. ${ }^{6}$

\section{Resettlement today}

In the UNHCR document entitled UNHCR Projected Global Resettlement Needs 2011 we can read that "Resettlement is about needs, not wants" (UNHCR, 2010, p. 2). Most refugees, it is argued, want to return home "in peace and safety". However this is not always possible and local integration in their country of first asylum is not always feasible either. Resettlement to a third country then becomes the only durable solution available for some of them. However, not all refugees who qualify for resettlement are actually resettled. In fact many refugees under UNHCR's mandate who are eligible for resettlement are not even referred to resettlement countries by UNHCR. As Loescher and Milner (2003) state:

...current resettlement efforts are limited as a result of programme constraints, resource constraints and procedural constraints. The overwhelming majority of refugees in protracted refugee situations could be eligible for resettlement, but a lack of resettlement opportunities and of resettlement staff to prepare submissions, and inefficiencies in the process of preparing and submitting a resettlement case, have resulted in the underuse of this durable solution. (p.613)

\footnotetext{
${ }^{6}$ The remaining criteria were: 'Survivor of violence \& torture' $(17 \%)$, 'Woman-at-risk' (9\%), 'Medical needs' (3\%), 'Family reunification (1\%) and 'Elderly refugees' (1\%). (UNHCR, 2011b)

7 "In response to this mismatch, a number of resettlement countries, especially the US, have been developing procedures to resettle groups of refugees, such as the Sudanese Lost Boys, and means of enhancing both UNHCR's resettlement capacity and the capacity of other organizations, especially NGOs, to make resettlement referrals and the support the processing of resettlement cases" (Milner 2005).

Canada have also resettled some people on the basis of group resettlement: "In 2003 Canada piloted a group resettlement project in which individual assessments were bypassed with 780 Sudanese and Somali refugees from Kenyan refugee camps. Approximately 1,000 Afghans came from Central Asia under the same program in 2004 and 810 Burmese refugees from Thailand were resettled over fall 2006 and early 2007" (Labman, 2007, p. 42).
} 
As for those who are referred by UNHCR to one of the resettlement countries, ${ }^{8}$ resettlement is not guaranteed either since, according to UNHCR (2011), the resettlement needs have, at least since 2005 , been higher than the resettlement places provided by the resettlement countries: "the provision of resettlement places has not kept pace either with the increased submissions or with resettlement needs" (p.4). The situation is particularly serious for 2011 since if the resettlement places available remains stable it will be possible to resettle only about $46 \%$ of the 172,300 persons identified as being in need of resettlement. This would leave more than 90,000 vulnerable refugees in need of resettlement without any solution (UNHCR, 2010). It is important to mention here that "[w]hile UNHCR may refer refugees under its mandate to resettlement countries for their consideration, it does not have the authority to resettle refugees" (Milner, 2005, p. 522). Resettlement countries are in fact independently responsible for determining the number of refugees they resettle as well as under what criteria.

This situation has been considered by Labman (2007) as the primary difficulty with resettlement. She argued that "[u]nlike the obligation on all signatory countries not to refoule refugees at their borders, there is no requirement that signatory states bring refugees to their borders $[\ldots]$ " and concludes that "the Refugee Convention is, therefore, reactive in its structure. (p. 38). Labman thus recommends that UNHCR "provide[s] a more comprehensive model and operational guidelines to which states can choose to subscribe" (p.43). The malleability of resettlement as an instrument for protection,

\footnotetext{
${ }^{8}$ As of 2011, the pool of resettlement countries to which UNHCR sends resettlement submission counts 24 countries. These are: Argentina, Australia, Brazil, Bulgaria, Canada, Chile, the Czech Republic, Denmark, Finland, France, Iceland, Ireland, Japan, the Netherlands, New Zealand, Norway, Paraguay, Portugal, Romania, Spain, Sweden, United Kingdom, Uruguay, United States of America. For 2010, the top three resettlement countries (by number of submissions by UNHCR) were: United States $(85,109)$, Australia $(7,287)$, and Canada $(6,911)$.
} 
Labman (2007) argues, allows States to manipulate resettlement in order "to obfuscate an unwillingness to meet their legal obligations under the Refugee Convention through a replacement of refugee protection by migrant selection" (p.35). This is so much so that UNHCR (2001) emphasized that resettlement must be seen as a "complement to other protection and assistance efforts and not as a substitute for asylum." Criticisms were also formulated against Canada's Immigration and Refugee Protection Act (IRPA). In 2001, Michel Casasola (then director of the Refugee Office of the Roman Catholic Diocese of London) wrote about the legislative package that would eventually become the IRPA in 2002 , that

$[u]$ fortunately the most negative aspect of the legislative package was that the many positive resettlement initiatives were presented as a counter to some of the more punitive actions the government planned in order to limit access to the refugee determination system in Canada. In fact, the resettlement initiatives became an important part of the selling of the bill to the Canadian public. [...]Resettled refugees were presented as part of the refugees using the 'front door.' And by providing refugees greater access, Canada suggested it had the moral authority to limit access to those refugees described as using the 'back door'. (Casasola, 2001, p. 79)

Ten years later, similar concerns were raised in response to the manner in which

the "Balanced Refugee Reform" was introduced by the Conservative Minister of Immigration, Jason Kenny (see for instance Gurzu \& Berthiaume, 2010).

\subsection{Canada and Refugee Resettlement}

In order to contextualize this thesis it is also necessary to provide an overview of resettlement in Canada. In the following section a brief history of resettlement in Canada as well as a description of the actual Canadian refugee system with an emphasis on GARs is provided. Finally, a review of the small existing literature addressing GARs and resettlement in Canada is presented. 
Although it can be argued that forcibly displaced persons have been granted asylum on the territory now known as Canada since, at least, the $18^{\text {th }}$ century (Knowles, 2007), the actual Canadian refugee program has its root in the aftermath of WWII. In fact, less than two years after the end of the war; before an international agreement was reached on the resettlement of Europe's refugees, the Canadian government passed, in 1947, an order-in-council authorizing the entry of an initial 5,000 non-sponsored displaced persons. With this breakthrough, argues Knowles (2007), the movement of displaced persons and refugees to Canada began in earnest. Subsequent orders-in-council, passed between July 1947 and October 1948, would provide for the admission of an additional 45,000 of these people, many of whom would later sponsor European relatives. (pp.164-165)

These people were, however, selected by 'immigration teams' dispatched in Germany and Austria whose mission was to select able-bodied refugees who could then serve as a workforce in Canada. The screening process was also based on political views and ethnic stereotypes: leftists were then considered undesirable and "Canadian officials routinely rejected Jewish applicants, even though the Jews had been the most abused victims of the Fascists" (Knowles, 2007, p. 165). It was not until 1967 that these racist biases were removed from the immigration policy.

With the Immigration Act 1976 and its 1978 amendments, the government activity relating to the admission of refugees was no longer based exclusively on ad hoc decisions and cabinet orders-in-council. One of the provisions of the Act's objectives was the fulfillment of Canada's international obligations in relation to the United Nations Convention (1951) and the 1967 Protocol relating to refugees, which Canada had signed in 1969. The Act also provided a framework for "non-discrimination in immigration policy; and cooperation between all levels of government and the voluntary sector in the 
settlement of immigrants in Canadian society" (Knowles, 2007, p. 208). These new provisions allowed for the admission of refugees from outside Europe and in the late 1970s, Canada participated in the most significant resettlement response of modern history. ${ }^{9}$ Between 1979 and 1981, "Canada admitted 60,000 Southeast Asian refugees, the largest per capita reception of Boat People on the part of any country, and, to this day, the largest influx of refugees in this country's history" (Beiser, 2006, p. 58). The Canadian refugee program was far from being perfect and through the 1980s and 1990s the Canadian government received many critiques. Perhaps the most important critique was that the resettlement program, with its emphasis on 'ability to integrate' criteria, "amounted to cherry-picking" (Labman, 2007).

At the onset of the $2000 \mathrm{~s}$, considering the changing labour market, the anticipated demographic changes and the security of the country, the Canadian government "embarked on the first large-scale overhaul of Canada's immigration policy since 1976" (Knowles, 2007). The ultimate result was the Immigration and Refugee Protection Act (IRPA) that was assented on November 1, 2001 and came into effect June 28, 2002. Under IRPA, the resettlement program was founded on four key principles: (1) emphasis on protection rather than integration potential, (2) expedited processing of urgent protection cases, (3) rapid family reunion, and (4) closer relationships with partners. But although IRPA, for some, "reflects the importance Canada places on assisting those who are in need of protection but where no alternative lasting solution exist" (Orr, 2004), others nonetheless criticized it for still putting emphasis on the ability to integrate (Labman, 2007) . In fact, since IRPA, the 'successful establishment' criterion that

\footnotetext{
9 "More than 550,000 Indo-Chinese sought asylum in Southeast Asia between 1975 and 1979, of which 200,000 were resettled". (Milner, 2005)
} 
requires refugees to show that they have good settlement potential is waived for refugees designated 'vulnerable' or in 'urgent need'. However, there are very few cases referred on these bases each year. ${ }^{10}$

\section{Canadian refugee system}

The Canadian government admits refugees under two main classifications, sponsored refugees and asylum seekers (refugee claimants). While asylum seekers enter Canadian territory without refugee status and have their claims processed in Canada, sponsored refugees are granted permanent residence before coming to Canada with the support of a private sponsor or as GARs.

There exist three subcategories of GARs in Canada. The first one is the Convention Refugee Abroad Class. The people in this category are those who come to Canada following the process described above. They are people recognized as Convention Refugees (i.e. they must be outside their own country and have a wellfounded fear of persecution for reasons of race, religion, political opinion, nationality or membership in a particular group) who are in need of resettlement. The GARs interviewed in the present research were all from this subcategory. There is also the Country of Asylum Class which includes people in refugee-like situations but who do not qualify as Convention refugees and who are in need of resettlement. Members of this class must be outside their own country and must have been, and continue to be, seriously and personally affected by civil war, armed conflict or a massive violation of human rights. Finally there is a third subcategory called the Source Country class. People in this class do not have to be outside their own country but their country must meet specific criteria. There is a list of recognized 'source countries' that is being maintained by

\footnotetext{
${ }^{10}$ About 20 to 30 such cases are referred to Canada annually. (Orr, 2004)
} 
Canada. Members of this subcategory must also be in need of resettlement and be seriously and personally affected by civil war or armed conflict in that country or must have been detained or imprisoned as a result of exercising their civil rights, or, except for the geographic criteria, meet the definition of Convention refugee. ${ }^{11}$

Under the Canada-Québec Accord Relating to Immigration and Temporary Admission of Aliens signed in 1991, there is a sharing of responsibilities between the Federal and Québec governments with respect to immigration. ${ }^{12}$ In the area of resettlement it is the federal government that is responsible for refugee status determination as well as for applying the criteria related to health, security and criminality. The Québec government, however, has the right to select, from the pool of refugees recognized by the federal government, their own GARs. Québec has its own selection process of GARs that takes into account both the extent of the candidate's distress and his or her capacity to integrate. ${ }^{13}$

In Québec two programs fund the resettlement of GARs. The first one is the

\footnotetext{
11 The federal government is about to amend IRPA so as to erase the Source Country Class. See http://www.gazette.gc.ca/rp-pr/p1/2011/2011-03-19/html/reg3-eng.html
}

12 “Selon l'Accord Canada-Québec signé en 1991 déléguant au gouvernement du Québec la maitrise d'oeuvre de son immigration, notamment l'administration du programme des réfugiés sélectionnés à l'étranger, le Québec est tenu d'accueillir une proportion d'immigration humanitaire équivalente à son poids démographique au sein du Canada, soit environ $22 \%$ de l'immigration humanitaire accueillie au niveau de l'ensemble du Canada. En contrepartie, le gouvernement fédéral accorde au gouvernement du Québec une contribution annuelle calculée selon une formule établie dans l'Accord. La contribution couvre les services d'intégration et de francisation y compris la reinstallation des réfugiés dont le Québec est responsable (TCRI, 2007, p 4). Le montant prévu de la contribution versée au Québec pour 2011-2012 sera d'au moins 258,4 millions \$, soit une somme bien supérieure à celle véritablement investie dans l'accueil des nouveaux arrivants" (Guyon, 2011)

${ }^{13}$ It is interesting to note here that at the federal level (through IRPA) the ability to integrate was de-emphasized but that the provincial level it remains an important feature of the selection process. There seems to be nothing in the literature that addressed this issue. 
Programme d'Accueil et d'Installation des Réfugiés (PAIR) that covers basic needs upon arrival. The second program is the Volet 2 of the Programme d'Aide aux Nouveaux Arrivants (PANA) that funds the thirteen community organizations responsible for the delivery of resettlement services to GARs throughout Québec's territory. The refugee resettlement approach in Québec focuses on regionalization and local community support. While in other provinces refugees are for the most part resettled in "reception houses" in big cities with particular services geared towards refugees, in Québec refugees are resettled in various sized cities throughout the province and great emphasis is put on refugees to become autonomous quickly after their arrival (Guyon, 2011). Québec's strategy in terms of regionalization of immigration is to send the 1900 or so GARs it resettles each year outside Montreal in the following cities: Québec (480), Sherbrooke (295), Gatineau (225), Montréal (130), Laval (95), Brossard (95), Trois-Rivières (90), Drummondville (90), Saint-Hyacinthe (90), Granby (90), Victoriaville (85), Joliette (70) et Saint-Jérôme (65) (Guyon, 2011; MICC, 2010). In each of these cities the government of Québec has contracted out the provision of resettlement services to a community organization. ${ }^{14}$

\footnotetext{
${ }^{14}$ The actual relationship between these organizations and the State is particularly tense. With the enactment of IRPA in 2002 and Canada's commitment at the international level to find solutions for protracted refugee situations, GARs with important physical and mental health issues started to arrive in both Canada and Québec. While the organizations providing resettlement services applauded this breakthrough they were, however, frustrated by the fact that no additional material and financial resources came from the Québec government. This situation had put enormous pressure on the resettlement workers and had aggravated the relationship between the 13 community organizations and the State to the point where the Table de concertation des organismes au service des personnesréfugiées et immigrantes (TCRI), that represents these organizations, called for a demonstration in front of MICC's offices in Montreal in June 2011 and threatened the government that if they were not ready to address the catastrophic situation under which these organizations work on a daily basis, other means would be taken.
} 


\section{GARs in Canada}

Although it has been argued that there exists a bias towards GARs on the part of the Canadian protection system (i.e. that GARs are considered the "legal" and "good" refugees while asylum seekers are deemed "illegal" and "queue jumpers" (Saillant, 2007)), very little has been written about them. Perhaps the most important contribution to our understanding of GARs comes from health-related research. For instance, Beiser's longitudinal research on the resettlement of more than 1,300 Southeast Asian refugees has shed light on different aspects of mental health in relation to resettlement (Beiser, 2006). He has demonstrated that although language ability and depression were not linked in the first two years of resettlement, by the end of the first decade in Canada, the absence of English language fluency was a significant predictor of depression, particularly among refugee women (Beiser, 2006). His study also highlighted the effects of time on mental health, the salience of pre-migration stressors, as well as the impact of discrimination on depression. Michalsky (2001) assesses Canadian health care services provided to Iraqi GARs and criticizes the fact that even though the government committed to accept them as permanent residents, it was unprepared to deal with their mental health issues. Other researchers have also exposed the various barriers to care for GARs. For instance McKeary and Newbold (2010) have classified the various barriers to health for refugees into (1) social/cultural barriers and (2) legal frameworks. The former include includes variables such as language/interpretation issues, isolation, poverty, and cultural competence, and the second includes health insurance and refugee status. McKeary and Newbold argue that although these barriers are not unique to refugees and can be experienced by the broader immigration population; they are exacerbated by the particular vulnerability of refugees. Focusing on the case of Somali GAR women, Spitzer 
(2006) also explores the various ways in which the health and well-being of Somali women in Canada have been impacted by government policy and public discourse. She states that the

...policies and practices that obliged many Somali women to wait three to five years to apply for permanent residency status, Eurocentric definitions of the family that constrain family unification strategies, and economic marginalization due to lack of recognition of foreign credentials have had cumulative adverse effects on the health and well-being of Somali women in Canada. (p.44)

Other contributions to the literature on GARs address economic issues. Jimenez (2004), for instance, argues that granting asylum to refugees is profitable for Canada not only economically but also socially. He calls for a turn from the current utilitarian approach to refugee selection to a more open and humanitarian approach. Similarly, DeVoretz, Pivnenko, and Beiser (2004), argue that refugees should not be selected on the basis of their potential contribution to the Canadian economy. Their study also demonstrates that although refugees' economic performance is less impressive than that of independent migrants, refugees do not constitute a major drain on the economy. As they say:

... although the economy may not be suffering, refugees - particularly the most recent arrivals - apparently are. Lower average wage earnings are consigning ever-greater proportions of refugees to the poverty ranks of Canadian society. This is a serious problem that calls for investigation of factors such as lack of recognition of credentials, and discrimination, which militate against finding jobs on the one hand, and job training programs and perhaps private sponsorship on the other, which may facilitate the integration process. (p. 30)

In the case of GARs, Chapter 4 shows that the institutional organization of the resettlement workers' work is also an element to consider when looking at the precariousness of refugees economic situation. In fact the coordination of resettlement at the local level is an important element of the GARs' integration process because it determines in part the services GARs would be able to access. These services can have an 
important impact on GARs economic situation. They include health services, education and transport.

The precarious economic situation of many GARs has an impact most notably on their housing conditions. As Murdie (2010) has demonstrated, refugees face the most difficult housing circumstances of all newcomers to Canada and affordability is the single most significant barrier to housing, regardless of location. He also argues that GARs have greater support than refugee claimants and are thus able to find better housing at the initial stage of their resettlement. Sherrell (2010), however, provides a more nuanced analysis and claims that it is not only the legal status that influences the housing conditions of refugees. For instance ethnicity, family size and composition, literacy, health, language as well as low employment participation, and high housing costs are also interacting in the determination of the housing experience of GARs (and other refugees). In Chapter 4, the question of housing for GARs is addressed from the standpoint of the work of resettlement workers. It shows under which conditions resettlement workers must find housing for GARs and provides a description of how the resettlement process itself is involved in the housing conditions of refugees.

The reliance on a social network is also an important determinant not only of the housing condition for GARs but of their overall integration as well. Using a social capital framework, Lamba and Krahn (2003) have shown that

[d] espite the traumas associated with becoming a refugee, most adult refugees remain part of at least some familial networks. A large minority are connected with more extended family networks, and almost half plan to build these networks by sponsoring other family members. As resettlement continues, more extensive extra-familial networks involving neighbors, co-workers and employers, other community members, and a wide range of service providers are constructed. These many formal and informal social networks are extremely valuable, providing much-needed support and assistance when refugees are faced with financial, employment, personal, or health problems. (p.335) 
The social networks of GARs also impact on their post-resettlement migratory patterns. In fact is has been argued that that refugees seek social support by resorting to secondary migration i.e. by moving from initial resettlement cities to join other people who can provide them with various types of support. For instance Simich (2003) has analyzed how "the resettlement bureaucracy, driven by political as well as humanitarian interests, attempts to control the process, in contradiction to refugees' preferences" (p.386) and called for a greater participation of GARs in the decision regarding their city of final destination (see also Simich, Beiser, \& Mawani, 2002; Simich, Beiser, Mawani, \& O'Hare, 2001). The present thesis shares with Simich an interest in the bureaucratic aspect of resettlement. However instead of arguing that refugees are deprived of a voice in the resettlement process I use the generous notion of work to look at how they are already participating in the institutional organization of resettlement i.e. how their 'work' coordinates with the work of others so as to produce resettlement.

In fact, very little research addresses the institutional arrangements of the resettlement process in Canada. The work of Francine Saillant (2007) on resettlement of GARs in Québec is, in fact one of the few studies addressing resettlement as a process within a local framework. By linking humanitarianism to the "communautaire", Saillant exposes the discourse on refugees in relation to resettlement and highlights some tensions that exist between the desires for refugees to become full-fledged citizens while remaining 'subjects with memory'. She also examines the institutional treatment of the refugee as a needy subject. She concludes:

Car il s'agit, pour les réfugiés, d'être reconnus autrement que comme simple ressource culturelle et économique, et de devenir de véritables citoyens tout en demeurant sujets dotés de mémoire et d'histoire - tout le contraire du confinement à l'identité d'aidé et d'usager des services sociaux et communautaires, et du sujet nu de l'humanitaire. La structure humanitaire canadienne, aux apparences ouvertes quant à l'image qu'elle 
projette à l'extérieur du monde et engage face aux organismes internationaux, n'y contribue que bien partiellement. Elle laisse, certes, le réfugié dans un espace liminal, une zone gris où se mélangent droits et non-droits, citoyenneté précaire et citoyenneté promise. (p.86)

While Saillant's contribution points to the importance of linking the global dimension of resettlement to its local manifestation, she remains extremely vague about the actual ways in which resettlement "is put together" (to use one of Smith's preferred expression). Her discussion of "l'humanitaire" and of humanitarianism as a discourse does not provide a material and empirical understanding of the resettlement process.

Almost ten years before the publication of Saillant's article, Randy Lippert (1998) had provided an original analysis of refugee resettlement in Canada. Drawing on the work of the "Anglo-Neo Foucauldian" school (Burchell, Gordon, \& Miller, 1991; Miller \& Rose, 2008; Rose, 1993, 1996, 1999), Lippert demonstrated that the focus in Canada, of the community in resettlement, the dominance of the partnership between the State and community organizations or private organizations as a preferable form of association, and the ensuing shift of resettlement responsibility out of the State (mainly to community organizations and religious organizations), was consistent with a shift to a form of rationality that Nicolas Rose (1993) called 'advanced liberalism.' This particular rationality is associated with moving responsibility to local levels, replacing the 'social' by the 'community', (Rose, 1996) and shifting responsibility away from the State towards individual subjects. ${ }^{15}$ While I do not use this theoretical framework in the present study I nonetheless provide in Chapter 4 an ethnographic description of what it is to work within such rationality thus expanding our knowledge of refugee resettlement in Canada.

\footnotetext{
${ }^{15}$ Lippert also suggests, however, that refugee resettlement cannot be understand only in terms of advanced liberalism and that other rationalities were at play, one of them being a pastoral rationality rooted in Christian values.
} 


\subsection{An Institutional Account of Resettlement}

Before we can move to the substantive part of this thesis it is essential to present an overview of the resettlement process as a whole from selection abroad to the integration in the resettlement country. Such an overview necessarily involves generalizations and cannot represent adequately the actual ways in which resettlement happens. However it can serve as a background for a more detailed analysis of this complex process such as those presented in Chapters 4 and 5 . In order to present such an institutional account of resettlement, I draw on my observations at APO as well as on the procedures described in the UNHCR Resettlement Handbook(UNHCR, 2004), the CIC Overseas Selection and Processing of Convention Refugees Abroad Class and Members of the Humanitarian-protected Persons Abroad Classes (CIC, 2010), and the Guide des Procédures d'Immigration Composante 2: Immigration Humanitaire (MICC, 2006).

As we have seen above, UNHCR has, over the years, attempted to harmonize and standardize its resettlement activities. One of the ways in which it did so was through the publication of the Resettlement Handbook and the eight criteria for eligibility for resettlement. Also, UNHCR implemented of a five-step process (Milner, 2005) for resettlement. Although it would be wrong to assert that resettlement always occurs in the same way no matter where it is being conducted, we can nonetheless provide an ideal type of the resettlement process using the five-step model described by Milner (2005):

The first is the identification of refugees in need of resettlement on the basis of their eligibility according to above criteria. Next, a resettlement dossier is prepared and submitted to a resettlement country for adjudication. If accepted for resettlement, refugees then go through the pre-departure formalities before they arrive in their resettlement country and begin the process of integration. (522) 
Since a presentation of this process is largely absent from the literature on resettlement I propose here to describe the 'formal' process by which GARs are resettled to Gatineau, Québec by applying Milner's characterization of resettlement as a five-step process.

\section{Case identification}

The institutional treatment of GARs typically starts with the work done in UNHCR field offices. ${ }^{16}$ These offices are located near urban refugee populations, refugee camps, and refugee settlements thorough the world. Regardless of the field context in which they operate, UNHCR staff must prepare and process resettlement submissions by following similar procedures. The first step of the resettlement process is the identification of refugees in need of resettlement consideration. This is made possible through internal reference (e.g. by various sections within a field office), external reference (e.g. by NGOs) or by requests made directly by refugees themselves at a UNHCR office. Once a referral has been made, it is necessary to assess individual resettlement needs. A UNHCR staff member goes through some determination process, which includes the preparation of a file and the collection of basic bio-data. S/he may interview the refugee previously identified as being a potential candidate for resettlement in order to do so. Then, the UNHCR staff member verifies the registrations details and the refugee status. These procedures are designed to assess and ensure the credibility and need of the applicant.

Preparation and submission of cases

\footnotetext{
${ }^{16}$ Other organizations can be designated as referral organizations but no organizations have been designated as yet (Orr, 2004). Refugee applicants can also present themselves directly to a visa office but "Direct access (self-referrals) to visa offices by refugee applicants is the exception and not the norm" (CIC, 2010). For simplifying purposes, direct referrals are not addressed in this institutional account of resettlement.
} 
The second step consists of preparing and sending the resettlement submission. In addition to a substantiated explanation of the need for resettlement, a comprehensive outline of the refugee claim and of the UNHCR determination of the case is included in the resettlement submission package. Then, the UNHCR branch office makes an actual submission decision. Once it has been decided that a particular case should be considered for resettlement it is then determined to which resettlement country the submission should be sent. Such a decision is primarily based on a range of considerations, including the selection criteria of resettlement countries, the admissibility priorities of countries, language and family links. Once the resettlement country has accepted the case for resettlement, pre-departure formalities are organized.

Pre-departure formalities

It is usually the International Organization for Migration (IOM) that, in coordination with the visa office, organizes the transport of GARs from their country of asylum to their country of resettlement. IOM is an intergovernmental organization whose purpose is "to help ensure the orderly flow of international migrants, to promote international cooperation on migration issues, to aid in the search for practical solutions to migration problems; to contribute to international solidarity by providing humanitarian assistance to people in need" (Department of Labour, 2008, p. 22). IOM also supports UNHCR and resettlement countries by providing language training and cultural orientation for refugees to be resettled. IOM staff members accompany refugees to the airport and provide support for the departure. It is important to note, however, that the 
cost of travel has to be assumed by the GARs through government loans that they will have to start repaying within the first months of their arrival in Canada. ${ }^{17}$

\section{Arriving in Canada}

GARs destined for resettlement to Québec arrive at the Montréal--Trudeau airport where they are met by a representative of the MICC and, if necessary, an interpreter. The representative of MICC completes administrative formalities and once GARs' visas have been checked they are put on a bus to Ottawa. ${ }^{18}$ There, a resettlement worker from Accueil-Parrainage Outaouais (APO) greets the GARs at the bus station and then drives them to a temporary housing facility in Gatineau. During the first week of their arrival the APO resettlement worker will help the GARs find an apartment, open a bank account, buy clothes, furniture, basic household items, and register with different government agencies. $^{19}$

\section{Integration}

Throughout the first year after arriving in Canada, the GAR will benefit from the help of APO for matters such as completing forms or getting information on health, education, and translation services to help with the medical appointment or legal matters. In Québec, GARs have access to financial assistance from the provincial government

\footnotetext{
17 "In the case of refugees, an immigrant loan may be authorized to cover the cost of transportation to Canada, immigration medical examinations, and where necessary transportation to the interview with the visa officer. A refugee must demonstrate the need for and the potential to repay the loan. Refugees are required to begin repaying the loan (in monthly installments) shortly following arrival in Canada. Under certain circumstances loan repayment may be deferred for up to two years. Special needs refugees may be granted financial assistance in the form of a contribution which does not have to be repaid". (UNHCR, 2004, p. CAN/4) For more information on this issue see the End the burden of transportation loans campaign by the Canadian Council for Refugees at http://www.ccrweb.ca/transportationloans.htm

${ }^{18}$ In the case of large families, a chartered bus brings them directly to their temporary housing facility in Gatineau.

${ }^{19}$ Chapter 5 offers a more extensive description of this process.
} 
through the PAIR which covers certain services such as clothes, temporary housing, winter clothes, interpreting services, material aid for basic food and household products as well as some essential pieces of furniture (e.g. bed, table, chairs). As permanent residents, GARs also have immediate access to the Social Assistance Program that provides last-resort financial assistance to people. As for healthcare, GARs are covered by the Interim Federal Health (IFH) Program. Once GARs access the provincial health insurance (usually 90 days after their arrival) they will only be eligible for limited coverage under IFH for the remaining time in the PAIR program (which usually last 12 months).

French is the official language of Québec and the Québec government provides French courses to GARs who are not fluent in French. These courses are not mandatory but are highly recommended. As an incentive, the MESS also gives a weekly allowance of $\$ 40$ to those who attend the French course. In terms of employment, GARs are encouraged to seek jobs as soon as they can. There exist many state and non-state agencies that help GARs and other immigrants to find employment. Three years after their arrival, GARs become eligible for citizenship. In order to acquire citizenship, they have to pass the citizenship test ${ }^{20}$ and attend a citizenship ceremony in which they take the oath of citizenship. ${ }^{21}$

\footnotetext{
${ }^{20}$ Information on the citizenship tests as well as a copy of the study guide can be found at http://www.cic.gc.ca/english/citizenship/cit-test.asp

${ }^{21}$ The oath of citizenship as well as some information on the citizenship ceremony can be found at http://www.cic.gc.ca/english/citizenship/cit-ceremony.asp
} 


\section{Conclusion}

Resettlement is a complex process. On the international level, it is simultaneously an instrument of protection, a durable solution for refugees and an expression of international solidarity and burden sharing. It has its roots in the aftermath of WWII and has been shaped by the ideological and political tensions of the Cold War. Resettlement is now an integral aspect of the international refugee regime and it is accomplished through the work of many people situated in different countries and working for various agencies. Canada is one of the top three resettlement countries and resettles about $10 \%$ of all resettled refugees annually. From these, about $25 \%$ are selected by the government of Québec as GARs.

The literature on resettlement in Canada is still quite modest. While there exists some research on GARs around certain issues such as health, housing, and employment, very few studies have looked at the resettlement process itself. The promising work of Randy Lippert on resettlement has unfortunately not been followed up by other similar research. While his focus on resettlement as being conducted under certain rationalities (mainly Advanced liberalism and pastorship) brings to light certain important aspects of the forces at play behind the process, it remains that it obscures (or at least does not show) the actual work being done by people. For this reason I think that ethnographic studies are required to shed light on the lived experience of those whose life is being coordinated by this complex process.

Resettlement definitively changes the lives of refugees but we know very little about how it changes their lives. More precisely we do not know much about what 
resettlement involves for refugees and how they experience it. This constitutes a huge and paradoxical gap in the literature. In fact, while so much is being written about refugees and about resettlement, we do not hear much about their relationship. In this thesis I argue that to bring the work of Dorothy Smith and her 'sociology for people' into the field of resettlement can generate significant contribution to our understanding of this process. Much of the literature relating to GARs takes their life conditions or their behavior as an object of study. What I propose in the following study is to start from GARs' experiences as well as that of resettlement workers and to focus on their activities in order to generate knowledge about resettlement as a process. By doing so this thesis contributes to an emerging literature on refugees that has departed from the mainstream problem-solving approach (e.g. Hyndman, 2000; Nyers, 2006). In contrast to the work of others in this emerging literature, however, the contribution of this thesis is more empirical than theoretical and, consistent with IE, is attentive to the actualities of people's everyday life and to their coordination. In the next chapter the experience of resettlement of GARs is discussed in the light of Smith's generous notion of work. 


\section{Chapter 4: The Long and Winding Road to Resettlement}

As we have seen, refugees are often conceived as 'problems' to which solutions must be found. Resettlement is definitively one of them. It is a solution being used in order to give protection to refugees, to release the pressure in certain countries of first asylum and to promote international solidarity and burden sharing. While resettlement is in part accomplished 'for' (certain) refugees it is unsettling to find so little written about their experience of resettlement. In fact most the studies of resettlement take a top-down approach to the process and discusses it in relation to States and International law. The goal of this chapter is to add to the existing literature on resettlement by highlighting the active participation of refugees in the resettlement process. With the help of the generous concept of 'work' developed by Smith $(1987,2005)$ and some of her followers (Diamond, 1995, 2006; Gregor, 1994, 2001; Manicom, 1995; McCoy, 2006; Mykhalovskiy \& McCoy, 2002), I want to look at what refugees 'do' during the resettlement process abroad. More precisely I discuss the accounts provided by my GAR informants and call attention to their 'work' as refugees who were resettled in Gatineau. In this chapter I argue that my informants were far from being passive in their resettlement and that their participation is/was an essential, albeit not recognized, feature of the resettlement process. By participation here I mean more than 'being' a refugee under UNHCR mandate. Using the generous concept of work as a heuristic device enables me to emphasize different aspects of my informants' stories as they pertain to resettlement. It allows me to direct my attention to what GARs 'do' throughout the resettlement process and to "fill it" with experiential accounts. In this chapter, work refers to the actual doings of refugees throughout the long and complex process of resettlement to a third country. Although the 
research on which this thesis is based does not allow for an extended exploration of the resettlement process as a whole, especially of the elements of the process that took place outside Canada, and while it does not claim to be representative of all resettlement experiences, this research nonetheless made it possible to identify some of what refugees do abroad prior to their arrival in Gatineau. As such I was able to achieve two things. First, I provide a novel way of addressing refugee resettlement that allows us to discover the hidden face of resettlement i.e. the lived experience of refugees who are being resettled. Secondly I generate different questions for further inquiry of the institutional organization of refugee resettlement.

In order to do so, I first look at the use of interviews in the resettlement process and to what it entails for refugees. I argue that my informants' constant re-telling of their traumatic experiences of exile constitutes a form of work that an analysis of refugee resettlement must acknowledge. Second, I show how waiting is a form of work that my informants engaged in for quite a long time before coming to Gatineau. I discuss how waiting can be conceived as work and show some of the investigative potential of doing so. I conclude by discussing the implications of using 'work' as a research tool and briefly sketch other forms of work that were not addressed in the chapter but that could be explored in further research.

\subsection{Interviews After Interviews: Resettlement and Remembering Work}

The experience of refugees, and especially GARs, is characterized, among other things, by the constant submission of oneself to interviewing procedures. Interviewing is in an integral aspect of both refugee status determination (RSD) and refugee resettlement. 
In the following section I describe the use of these interviewing procedures and look at what it involves on the part of refugees.

Refugee status determination and interviews

In the case of GARs, it is typically the UNHCR that refers them to the Canadian government for resettlement (see Chapter 1). But well before any person is considered for resettlement in Canada, he or she has first to be recognized as a refugee, at minimum under the Mandate of the UNHCR. As Kagan (2006) argues, the "UN's refugee agency effectively decides among asylum-seekers who can be saved from deportation and in some cases released from detention, who can get humanitarian assistance, and often who can apply to resettle to third countries" (p. 2). In fact, each year "UNHCR's offices decide on the fate of more than 80,000 individuals, which makes UNHCR the biggest RSD decision-maker in the world" (Smrkolj, 2010, p. 168).

In order to decide if someone is a convention refugee, a UNHCR Protection Officer conduct one or multiple interviews with that person. For the officers responsible for RSD, the task is threefold. He or she has to

(i) Ensure that the applicant presents his case as fully as possible and with all available evidence.

(ii) Assess the applicant's credibility and evaluate the evidence (if necessary giving the applicant the benefit of the doubt), in order to establish the objective and the subjective elements of the case.

(iii) Relate these elements to the relevant criteria of the 1951 Convention, in order to arrive at a correct conclusion as to the applicant's refugee status. (UNHCR, 1992, p. 34) 
Credibility assessment is therefore an essential feature of RSD ${ }^{22}$ It relies almost entırely on the applicant's testımony "sınce asylum-seekers can rarely specifically corroborate the central elements of therr claims" (Kagan, 2002-2003, p 367) This puts enormous pressure on applicants and their ability to delıver a narratıve that convinces the UNHCR Protection Officer that they have a well-founded fear of being persecuted if they are sent back to their country of origin RSD is not an objective enterprise and " $[\mathrm{t}] \mathrm{he}$ assessment of credibility is inevitably prone to some subjectivity because it calls for an adjudicator to judge the trustworthiness of another human being Emotional impressions of a person and "gut feelıngs" can have a substantial impact" (Kagan, 2002-2003, p 375) Refugee resettlement and interviews

Interviews are also used by UNHCR to determine if a refugee should be referred to a resettlement country for their consideration Upon reception of resettlement referrals at the field office, an evaluation is made of the resettlement needs of the case referred (this procedure is called Resettlement-Needs Assessment) An 1nterview is then normally scheduled with the refugee whose case is being considered for resettlement This interview is organızed around the Refugee Resettlement Form (RRF) and its different sections

Other than information on the principal applicant (PRA), his or her family members and other close relatives (including his/her spouse's close relatives), the form asks for the languages spoken by all the applicants as well as their level of education In order to fill out the RRF, the UNHCR officer also has to ask about any travel/1dentity documents held by the PRA and list all the countries of transit in which the PRA has

\footnotetext{
${ }^{22}$ Neither the 1951 Refugee Convention nor the Statute of the Office of the UNHCR mentions credibility, but negative credibility assessments are a leading reason for rejections in most refugee status determination systems (Kagan, 2002-2003, p 368)
} 
transited or resided since he/she is in exile. Medical status and criminal or detention records are also part of the RRF interview. After the interview, the resettlement officer also needs to write the refugee claim as well as an assessment of the need for resettlement. If necessary, a special needs assessment and additional remarks are joined to the RRF which is then transferred to the branch office where the resettlement submission is prepared. Once the case is complete, the resettlement submission is sent to the country of resettlement. In the case of Canada the resettlement submission is usually sent to the nearest Canadian visa office. There, an agent will evaluate the case and may schedule an interview with the applicants.

Remembering as Work

In their journey from their country of first asylum, all my GAR informants went through a process of Refugee Status Determination (RSD) and of resettlement assessment at the hands of the UNHCR. They also had to go through the resettlement evaluation process at the level of the Canadian government. As shown above, the resettlement process relies intensively on the use of interviews. The questions that preoccupy us here are what kind of work (in Smith's sense) is involved on the part of the refugees through these procedures? And what does talking about their uprooting entail for refugees?

As we have seen, the purpose of interviewing throughout the resettlement process (starting with RSD) is to determine the eligibility and credibility of the applicant's case so as to ensure that the refugee to be resettled is a genuine refugee in need of resettlement. This is achieved through multiple interviews conducted by various people at various stages of the resettlement process. All these interviews centre around the applicant's story of exile and especially on the reasons that lead them to think that they will be persecuted if they go back to their country. In the case of the interviews around the Resettlement- 
Needs Assessment and the RRF the applicant is also being asked to explain why he/she cannot remain in his/her country of first asylum. This points to the hierarchy of durable solutions mentioned in chapter 1 where resettlement is conceived as a solution of last resort when both voluntary repatriation and local integration are not achievable.

The repetitiveness of interviews accentuates the importance of remembering the traumatic events that lead refugees to escape from their home. Remembering in this context is definitely a form of work that connects with the doings of the various people at work within the institutional organization of refugee resettlement.

The work of remembering traumatic events is a particular kind of work. It involves an intense emotional charge and is a challenging and unpleasant activity. This was brought to my attention when one of my informants specifically asked that we did not talk about the events that pushed him in exile because he wanted to forget what happened back then. To forget is antithetical to resettlement work because of the institutional processes of RSD and resettlement assessment.

As Mr. Bemba suggests below, forgetting, or at least attempting to do so, becomes institutionally relevant only after resettlement has occurred. To forget seemed in fact to be one of Mr. Bemba's priorities after his arrival in Gatineau. During my shadowing experience I had the chance to follow a resettlement worker and Mr. Bemba to the grocery store. We were there to buy the Bembas their first groceries on the day they moved from the hotel to their apartment. At one point, Mr. Bemba asked where he could find beer. He told me: “La bière c'est bon. Ça va m'aider à oublier ce qui s'est passé en Afrique... On peut oublier ça maintenant". Mr. Bemba had been in Gatineau for hardly a week and he felt like he could now start to forget. This was made possible in part because the focus of the institutional organization of GARs' resettlement once they are in 
Gatineau shifts from one's past to one's future. After their arrival in Gatineau, the focus of the institutional processes that shapes the everyday life of GARs then becomes oriented towards their integration into Québec society through various means such as becoming tenants, holding a bank account, applying to provincial health insurance, learning French or improving their French language knowledge, receiving social assistance, etc. (see next chapter). Ultimately the GARs will be stripped (at least institutionally) of the refugee label and will become a permanent resident like any other and, possibly, a Canadian citizen.

Before this happens, however, the GARs need to recollect the events that preceded their flight from their own country at several moments prior to their resettlement. Although, as it has been suggested above, the remembering of these events could represent an arduous emotional task, the recollection of events itself, however, seems to be less difficult. In fact, when I asked Mr. Banga if it was hard to recall his story, he answered as follows:

Mr. Banga: Oui bon...quelque chose que vous avez vécu ...au moins les grandes lignes vous les savez...certains détails peuvent vous échapper mais si c'est un nom de quelqu'un qui vous a agressé vous direz alors «tel m'a agressé »... « tel m'a sollicité pour me joindre au mouvement »... «Pourquoi vous ne pouvez pas rester dans le pays voisin l'Ouganda? ...Je ne pouvais pas aller en Ouganda parce qu'il y avait tel, tel et tel qui travaillais là-bas et qui me connaissait très bien et qui était de la partie adverse...je ne pouvais pas rester là ». Alors tout ça là...des noms comme ça, ça ne vas pas vous échapper...je ne pense pas. Alors les grandes lignes vous les aurez toujours. Et là moi je me dit que si on me faisait encore une interview en détail aujourd'hui je peux m'en sortir.

Here, Mr. Banga suggests not only that he remembers certain elements of his story of exile easily but also that this remembering is intimately linked to the interviewing procedures he was submitted to. By referring to an interview setting, Mr. Bemba thus highlights the dialogic dimension of his remembering work. 
In fact, the remembering work of GARs involves not only the recollection of an important event but also the telling of their stories to interviewers whose positions within the institutional organization of refugee resettlement allow them to scrutinize and evaluate these stories so that they can be written up and made institutionally actionable (or not).

The refugees I interviewed told me that they knew that the people asking them questions were looking for errors and contradictions in their testimonies. Here, is an illustrative excerpt from my interview transcript from my conversation with Mr. Banga:

\section{Me : Et votre histoire par rapport au Congo vous l'avez répété souvent?}

Mr. Banga : Oui! Bien sur! Vous ne vous arrêtez jamais. Même des précisions là...ils vérifient même si vous vous trompez de date et tout ça là. Parce qu'ils veulent confirmer... au bout de tout ces années là...la longueur de toutes ces années là c'est pour justement vérifier l'authenticité de votre récit. Parce que souvent on vous demandera des questions précises là...quelque chose que vous avez dit en 2000...alors en 2007 on vous revient avec la même question. Vous risquez même de vous embrouiller là...et c'est à cela qu'ils s'attendent.

My GAR informants knew, to various degrees, that the interviewing procedures

they were submitted to were in fact hooked into different institutional processes and that 'they' were keeping track of what was said in these interviews. From the experience of GARs we can thus start to see that their remembering work is coordinated by relations of ruling that originate beyond the local setting of the interview and permeate it through the interviewing procedure conducted by the interviewer. As we have seen above, these interviewing procedures always involve the use of forms or interview grids that are designed outside the particular location of the interview and it is through these texts that the ruling relations of refugee resettlement coordinate the remembering work of GARs and the work of the interviewer. The interview, in short, happens as the ongoing accomplishment of the remembering work of refugees and the interviewing work of the 
interviewers (be it UNHCR or Visa Office staff members) and is organized around texts that are produced conceptually outside the site of interviews.

GARs' accounts of their remembering work also suggest that while being interviewed successively prior to their resettlement, they knew that their stories were evaluated and that credibility was assessed. Here's how Mr. Bakale told me about one of the interview he had to go through:

Mr. Bakale : Oui...ils demandaient l'histoire, ce qui fait qu'on ne peut pas retourner au Togo. Donc c'est comme la première entrevue qu'on nous a faite Donc si tu te contredis, c'est que tu as menti. Donc ils ont tous les papiers...

\section{Me: De la première entrevue?}

Mr. Bakale: c'est ca! C'est dans l'ordinateur, et ils ont fait sortir ca pour vérifier si vraiment ça concorde vraiment avec ce que tu as dit.

Mr. Bakale's understanding of his testimony as being written somewhere (in the computer) points to the textually mediated organization of the interviewing procedures within refugee resettlement and to the fact that the replicability of the applicants' testimonies allows for the assessment of credibility and authenticity of their claims as well as their admissibility to resettlement. In fact, the remembering work of GARs is conceptually organized by texts such as the UN Convention, the UNHCR Resettlement Handbook, the IRPA, etc. and materially inscribed in texts such as the RRF.

In brief, GARs' remembering work comprises the negotiation of emotions and memories and certain aspects are easier than others to achieve. But the usefulness of Smith's generous concept of work does not reside in its ability to typify people's doings but rather in its capacity at revealing that what people do inescapably coordinate with the doings of other. Remembering work as a conceptual device has allowed us to see that GARs are active in interviewing and that the constant recalling of events on the part of 
refugees and the consistency of their stories is an essential feature of refugee resettlement as an institutional process. As such it points to the institutional organization of this process and can serve as the starting point of an institutional ethnographic investigation as discussed in the conclusion of this thesis. The present research, however, neither allowed for the observation of the interviewing procedures mentioned above nor for the interviewing of either UNHCR staff members or Canadian visa officers, and therefore could not explore further this aspect of refugee resettlement. Yet, my GAR informants' accounts of resettlement suggest another type of 'work' they engaged in through the resettlement process, namely, waiting.

\section{2 "Les Années Passent": The Work of Waiting}

In his ethnography of a long term care facility in the United States, Timothy Diamond (1995) once described the elderly people waiting for their food in the morning (after a 14 hour fast) as a form of practice: "There each sat before breakfast, bib in place, eyes glued to the elevator. They waited quietly, with a wild patience, practicing patienthood, actively practicing the skills of silence" (p. 129). In order to highlight the active dimension of waiting, Diamond draws from Smith's concept of 'work in a generous sense'. In an interview with Smith, Diamond (2006) argues " $[\mathrm{t}]$ he beautiful thing about the generous concept of work is that it can include the doings of all kinds of things, including the work of doing nothing, which may be the hardest work of all" (Diamond, 2006, p. 51). Like Diamond's patients, my GAR informants also practiced active patienthood through the resettlement process. For them, however, the result of their patience was not the breaking of a fourteen-hour fast; it was the breaking of many long years of uncertainty and insecurity. The experience of resettlement for my informants 
was, in fact, characterized by long periods of waiting that sometimes added to their suffering. For my informants, the various stages of the refugee resettlement followed one another at a very slow pace thus allowing for long periods of institutional calmness where they cannot but wait to be called, once again, by the competent authority. From the time they left their homes up to the moment they arrived in Canada, my GARs informants spent between 10 and 17 years of 'waiting'. As Mr. Banga told me, his life was one of transit: it was a life stuck "in between" i.e. a life where he did not know where to go but knew he could not stay indefinitely where he were. He was condemned to wait and such a life does not allow for long term planning:

Me : Donc vous pendant 10 ans vous avez attendu. Vous semblez avoir été constamment dans l'attente de voir comment votre dossier...

Mr. Bange : Et comment! Vous n'avez pas le choix! Vous ne savez pas qu'est-ce qui viendra...il y en a qui disent qu'il faut partir en Afrique du Sud...mais aller en Afrique du Sud faire quoi? Parce que d'abord vous n'avez jamais l'argent pour vous rendre là-bas rien...donc vous êtes juste là...vous vivez au jour le jour...vous n'avez pas de projet à long terme.

\section{Me : Jamais de projet à long terme?...}

Mr. Banga : Non presque rien...

Resettlement is not a de facto durable solution for all refugees (see Chapter 2).

And it can take years before a refugee is considered for resettlement. During these years of waiting refugees can be active by trying to find organizations that could refer them to UNHCR. As Mr. Banga states:

Mr. Banga : Alors vous demandez la réinstallation chez HCR. Souvent HCR dit: "Nous ne savons pas où nous allons vous installer"...et à vrai dire, HCR est vraiment inondé par vraiment beaucoup de réfugiés...il y en a qui se sont sauvé du Burundi, du Rwanda, beaucoup...une grande partie venait du Soudan...des milliers, des milliers qui arrivaient du Soudan dans le camp...Et aussi à Nairobi...donc il y avait plein de réfugiés. Et le Kenya c'est révélé le pays le meilleur pour essayer de recevoir les fugitifs. Alors...qu'est-ce qui s'est passé. Alors...quand vous...quand HCR ne peut pas vous réinstaller...généralement vous allez auprès des organismes 
qui aussi aident à la réinstallation...qui sont...qui travaillent en partenariat avec le HRC. Alors vous allez frapper partout là...et vous expliquer et démontrer le sérieux de votre vie à Nairobi...vous ne pouvez pas travailler...

No matter how active one is in his/her waiting, the outcome of this work is often uncertain. The unpredictability of the refugee's future is also exacerbated by what, drawing on Darville (1995), could be called 'organizational illiteracy' i.e. the fact that refugees do not (always) know 'how things work' at the institutional level:

Mr. Banga : Alors j'ai été à des organismes...Les organismes des fois ils vous écoutent...et s'ils croient que votre cas est sérieux ils vous donnent d'autres rendezvous...encore des rendez-vous... des fois ils disent « nous allons envoyer les dossiers quelque part "... on ne vous dit pas où. Ils disent que peut-être un jour vous serez appelé par un autre organisme qui pourra s'intéressé à vous etc. Au bout de des années...des fois ça prend six mois, des années...les années s'écoulent comme ça...c 'est alors qu'ils renvoient encore...un moment donné encore je crois qu'on envoi votre dosser au HCR encore...qui peut dire celui-ci peut être réinstallé...je ne sais comment... Alors le HCR va vous demander...il va encore vous appeler...c'est lui qui chapeaute tout...pour poser des questions en vue d'une réinstallation. Finalement on trouve que HCR nous appel on ne sait pas comment... Sinon on avait déjà écris beaucoup de lettres qui montrait l'insécurité... Et on vous répond que vous ne répondez pas aux critères...et ils ne vous disent jamais ce que sont les critères.

For refugees, organizational illiteracy can give rise to anxieties $v i s-\dot{a}$-vis the various institutional procedures at play in refugee resettlement. For instance, it can lead refugees to wonder if their cases are being properly processed:

Mr. Banga: Chaque année vous renouvelez votre 'mandate' et à chaque année que vous allez là-bas vous faites les fingerprints...pour voir si c'est toujours les même personnes qui apparaissent. Il est arrivé une fois ou même ils sont venus nous visiter jusqu'à chez-nous à la maison pour voir comment nous vivions. Ils nous ont posé d'autres question à la maison...Et on se disait : " Mais qu'est-ce qui ne va pas? C'est comme si nous sommes des nouveaux...ils s'intéressent à notre dossier fraichement...qu'est-ce qui ne va pas?»

Mr. Banga's concerns are also part of waiting work. His interrogations in relation to the processing of his case point to the institutional organization of refugee management. It suggests that the waiting work of refugees coordinates with certain 
procedures involved in the management of refugees and that waiting work is not performed in isolation. Rather, it is the product of a particular institutional arrangement that includes not only the work of paid employees working for organizations but also the waiting work of refugees. Such work includes, among other things, the emotional management of the various anxieties and concerns produced by this institutional arrangement.

During the period that separates exile from resettlement, different events challenged my informants' patienthood. For instance while they waited for their case to be processed, they witnessed other refugees being resettled. As Mr. David recounts here, this situation can sometimes create tensions that refugees need to manage.

Mr. David: Parce qu'au fur et à mesure que ces effectifs viennent c'est les Ogonis, les nigériens... Nigéria. En même temps qu'ils viennent à peine ils font trois mois, les États-Unis les avalent, c'est-à-dire qu'ils vont vers le États-Unis.

Me: Donc vous vous avez vu des Nigériens arriver, rester trois mois, et partir aux États-Unis?

Mr. David: Et être réinstallé là-bas. Mais quant à nous autres qui sommes du Togo, non.

Me : Vous ça été beaucoup plus long...

Mr. David: Beaucoup plus long. Parce qu'on considère que...nous n'avons pas...nous ne sommes pas dans les mêmes besoins que les nigériens....parce qu'ils ont essayé de scinder le truc là...

Me : Et est-ce que cela crée des tensions entre les Togolais et les Nigériens?

Mr. David : Ah bien oui!! Heureusement que le Togolais est vraiment....comme on le dit...placide. C'est-à-dire qu'il accepte les coups. Mais si c'était les Nigériens qu'on essayait de scinder de la sorte il y aurait des meurtres!

Mr. David was definitely at work there managing his frustrations and when he argues that if it wasn't for the peaceful character of the Togolese there would have been murders, he highlights quite eloquently the very fact that waiting IS an active dimension 
of resettlement For resettlement to happen as it does, refugees must peacefully wait their turn and actively practice the 'skills of silence'

Eventually, however, their turn came and my informants were selected for resettlement by the Canadian government This obviously marks an important point in their experience of resettlement It was a decision that was welcomed with joy and relief as demonstrated by Mr Bakale

\section{Mr Bakale Donc on nous a dit "vous avez été retenu pour le Canada 》}

Me : Et ça c'est une belle journée pour vous ça?

Mr Bakale Ah Oul' C'est la fêtel' Ça commencé donc là où on est maintenant Quand on te dit maintenant que tu vas au médicale c'est que c'est parti tu pars tu sats que tu t'en va bientôt Et c'est un soulagement oul'

For my GAR informants, however, the relief of knowing that they will be resettled in Canada was followed by another period of waiting In fact the processing of cases in the Canadian visa offices can be very slow This is especially true in the Visa Offices where my informants' cases were processed Accordıng to CIC's website, the processing tıme for GAR cases coming from Africa is the longest at the Visa Offices in Accra, Ghana (41 months) and Narrobı, Kenya (37 months) ${ }^{23}$ As a comparıson, the processing tıme in Cairo (Egypt) is 15 months and is of 11 months in Pretoria (South Africa) ${ }^{24}$

\footnotetext{
23 The Canadian Council for Refugees (CCR) even launched a campaign to raise awareness on the long delays at the Nairobi Visa Office According to CCR (2011), "Thousands of refugees in many different countries are affected by the long delays at Canada's Narrobi office Canada's visa office in Narrobi covers 18 countries in East and Central Africa These countries host hundreds of thousands of refugees, including Somalis, Eritreans, Ethiopians, Congolese, Sudanese, Rwandans and Burundians Many have already been waiting years for a durable solution, barely surviving in wretched camps or in precarious situations in the cities " [ ] "These long delays leave vulnerable refugees in dangerous situations for longer than anywhere else in the world" (CCR, 2011)

${ }^{24}$ For the processing time of all the Visa Offices see http //www cic gc ca/english/information/tımes/perm/ref-government asp
} 
In the following interview excerpt, my informant tells us that he usually counted 6 months between the different steps of the resettlement process after he knew he would be resettled in Canada:

\section{Me : Combien de temps entre l'entrevue à l'ambassade et les examens médicaux?}

Mr. Banga : 6 mois...C'était souvent ...nous comptions souvent des 6 mois...encore 6 mois oui. Et nous on a pu terminer les examens vite...mais il y a eu un enfant qu'on disait que ce n'était pas clair que...que l'enfant avait comme une ombre pectoral...qu'elle doit aller passer des $x$-rays...ça nous a aussi agacé... alors après elle est parti là et elle à fait 4 fois des $x$-rays...et ils ne trouvaient rien du tout...on se demandait si ce n'était pas une façon de nous torturer d'avantage...Après 6 mois c'est encore l'ambassade qui vas nous appeler... Et elle nous a dit que l'organisme qui s'occupe du transport des gens pourrait nous appeler...Alors après 6 mois encore on nous appela là-bas pour évidement les modalités du transports...on nous a fait signé quelques papiers...

Me : Et à ce moment-là vous savez que vous serez réinstallé au Canada?

Mr. Banga : Oui à ce moment là... Non... dès que vous passez par l'ambassade et que l'ambassade ne dit pas que vous vous contredisez dans vos propos, vous savez que définitivement vous viendrez au Canada. Mais il reste encore les dossiers médicaux, les casier judiciaires on fait ça aussi...ce sont des formalité...vous ne savez pas comment ça se passe mais il y a un bureau qui s'occupe de tout ça pour vérifier tout ça...vérifier qu'on n'avait pas d'antécédents tout ça là...pour tout le temps que vous êtes resté au Kenya que vous n'avez pas eu de litige avec le gouvernement. Alors il faut clarifier toutes ces choses. Alors 6 mois plus tard on nous appelle au bureau qui s'occupe du transport...je crois que c'est une parti de l'OIM...Alors là il ne se passe pas grand chose...ils nous disent seulement les dates.

\section{Me : À ce moment là il reste combien de temps avant que vous partiez?}

Mr. Banga : À ce moment là il ne reste que peu de temps [...] Alors après 2 mois vous vous retrouvez à l'aéroport, vous prenez l'avion et vous vous en allez au Canada.

Mr. Banga's accounts here shows beautifully how his waiting work after his selection by the Canadian government was coordinated by the processes (depicted in the institutional account of resettlement provided in chapter 1) that connects the work of people located in various sites such as the medical examination room, the visa office and 
the IOM. Consistent with Smith's sociology, we can say that Mr. Banga's waiting work was accomplished at the level of embodied experience and was accomplished in coordination with the work of others in places he could not see.

Ultimately, there is a moment in the journey of GARs when resettlement becomes 'real' i.e. that their knowledge about having being selected is transformed into their actual departure from their country of first asylum. One day, refugees who have been selected for resettlement in Canada actually pack up their belongings and leave. There is a clear shift in the narratives of the GARs I interviewed when they recount their departure from their country of first asylum. Up to this moment in their story, we can feel the weight of the waiting and the heaviness of uncertainty. Then, there is a precipitate acceleration in the narrative: all of a sudden, GARs are urged to hurry up and get prepare to leave promptly. Here's how Mr. Bemba depicts his departure:

Mr. Bemba: En 2011 le Canada nous à dit d'être prêt parce que tout est presque à jour. Et nous attendions encore. Et enfin le moment est arrivé. Préparez vous car à tel jour vous allez partir.

\section{Me: Ok. Et qu'est-ce que vous faites pour vous préparer?}

Mr. Bemba: Le HCR nous a donné quelque chose pour acheter des valises et tout ça.

\section{Me: Et la journée du voyage comment ça s'est passé?}

Mr. Bemba: On nous avait parlé le mercredi et nous sommes parti le dimanche. Et tout est brusque! brusque! Oui on doit tout faire vite vite. Alors on ne peut même pas en informer la famille.

After having waited for 14 years as refugees in the Democratic Republic of the Congo, Mr. Bemba and his wife, their nine children and their grand daughter had about four days to prepare their departure. As he mentioned, they did not had the chance to let other family members and friends know that they were actually leaving. And one of the 
first thing Mr. Bemba asked when he arrived in Gatineau was that if he could phone Africa to reassure his relatives and inform them that the whole family had been resettled in Canada and that everyone was well. This is an illustrative example of how what happens abroad affects what happens in Gatineau. This will be further explored in the next chapter, as we will turn our attention to the work of resettlement workers.

\section{Conclusion}

When we apply Smith's generous concept of work to the study of refugee resettlement we come to see refugees as participants in rather than recipients of resettlement. In fact, without refugees' active participation within the institutional organization of refugee resettlement, their resettlement would not be possible. Of course the GARs interviewed for this research all benefited from resettlement, but to limit our understanding of GARs as only recipients prevents us from seeing how resettlement shapes and is being shaped by the actions of GARs.

In this chapter, Smith's notion of work was used to highlight the active participation of refugees in the various interviewing procedures that characterized their journey from exile to resettlement. What was brought to our attention was that in order to qualify for resettlement my GAR informants had to learn to be interviewed and to retain a memory of key narrative points that described their exile. Although these memories are presumably traumatic they had to be repeated over and over to various people for different purposes. Moreover my informants knew, to a certain extent, that their stories were scrutinized and analyzed so as to assess their credibility. The repetitiveness of the interviewing procedures also created anxieties and concerns about the unfolding of the resettlement process. The interviewing of refugees is thus a dialogic event that involves 
the works of refugees and interviewers. And, as we have seen, the interview is also a textually mediated event i.e. that texts coordinate the unfolding and outcome of the interview.

The second form of work that this chapter has highlighted is that of 'waiting'. It was shown that the waiting that my informants were engaged in during the preresettlement phase constituted a form of work. This type of work is characterized by the impossibility of having long-term plans and the reliance on the resettlement process to set the pace of one's life. The waiting work of my GARs informants was coordinated in part by the "five-step" process described in Chapter 3 and by the work of people situated in various sites outside the local settings of my informants' waiting work. By using the notion of work to analyse this waiting, we can see how waiting is not only an outcome of the resettlement process but that it was an integral aspect of my informants' experiences of this process. When we look for instance at CIC's table of processing times at the various Visa Offices we see but a number (e.g. Nairobi -37 months). This number conceals the experiences of GARs and does not allow us to see what exactly this number means or involves for GARs. By starting with the GARs' experiences, we can get a better sense of what waiting means in terms of 'work' and we can start to see that GARs are playing an active role in this waiting not only in terms of managing their emotions but also in terms of waiting their turn and not revolting.

Of course 'remembering work' and 'waiting work' are but two examples of the myriad of activities involved in the resettlement process on the part of GARs. Other forms of work such as finding food, getting to various places (such as the Visa Office, the IOM offices, the medical examination room, etc.), "killing time", etc. were not addressed in the present chapter but could certainly constitute the focus of other studies. For 
instance, one could explore the ways in which refugees feed themselves and how the ruling relations of refugee management shape this activity. Or one could ask how refugees get to their interviews and how this coordinated with the institutional organization of refugee resettlement. The ways in which refugees kill time could also serve as the basis of an inquiry into the social relations of refugee life and offer an entry into the institutional organization of refugees. By asking "how do refugees spend their time and how is this shaped by extra-local relations?" we could investigate the ruling relations shaping the lives of refugees prior to their arrival in their country of resettlement. These are some of the potential foci of research suggested by particular attention paid to refugee's work.

In the next chapter however I turn my attention to the local provision of resettlement services in Gatineau. It is revealed how the institutional organization of refugee resettlement (including resettlement work performed by refugees themselves) is then taken up at the local level by the resettlement worker through their 'resettling work'. 


\section{Chapter 5: Of Work and Texts: The Everyday Experience of Resettlement Workers}

So far, I have looked at the resettlement process in general terms and provided an overview of the roles of the UNHCR, the federal and the provincial governments and of the community organizations in relation to the resettlement of GARs (Chapter 3). I have also depicted and highlighted the work refugees perform from their experience of exile up to their resettlement in Canada (Chapter 4). In this chapter I turn my attention to the everyday work of resettlement workers as they resettle GARs in order to see how this work coordinates with and is coordinated by the ruling relations of refugee resettlement. Drawing on the generous concept of work I argue that in their everyday work, resettlement workers are caught between the pressing needs of refugees on one side and institutional constraints imposed by exogenous forces on the other. The frustration brought about by this situation offers another entry point into the study of refugee resettlement. In this Chapter I first locate the work of resettlement workers as the 'end point' of the resettlement process. I then describe the local process of refugee resettlement in Gatineau, Québec from the reception of GARs up to their setting into their apartment by focusing on the work of the APO staff members and how their work fits within the institutional arrangements of refugee resettlement in Canada. I examine in greater detail an important challenge the resettlement workers face on a daily basis: the search for housing. Finally I look at how texts coordinated the work of resettlement workers and, by the same token, the resettlement of GARs in Gatineau. 


\subsection{Locating the Work of Resettlement Workers}

As we will see in this chapter, the work of resettlement workers is at the same time coordinated by texts and geared toward the textual production of GARs as immigrants (permanent residents). The relationship between GARs and the State in regards to their incorporation into the host society is textually mediated. This mediation is coordinated by the APO staff members so that through their work, they produce the GARs as a permanent resident (i.e. a Canadian citizen in potentia). ${ }^{25}$ This work is situated at the 'end point' of the complex of relations that organizes refugee resettlement from the country of first asylum (in the case of convention refugee class) or their country or origin (in the case of the source country class) to the country of resettlement.

The GAR is someone who went through various sites where resettlement happens (e.g. the refugee camp, the UNHCR resettlement office, the Canadian visa office, the medical examination room at the IOM office, the airports, the hotel, APO, the Centre Local d'Emploi (CLE)). However, there is another "trail" that happens simultaneously and that produces resettlement. This "trail" is constituted by a series of work-text-work sequences that transform the lived experience of those who fled from their home in search of refuge into textual forms that are institutionally actionable. These texts are assembled

\footnotetext{
${ }^{25}$ On their arrival in Canada all GARs are granted permanent residence. A permanent resident has the right to health care coverage, to live, work or study anywhere in Canada and to receive protection under Canadian law and the Canadian Charter of Rights and Freedoms. A permanent resident must pay taxes and respect all Canadian laws at the federal, provincial and municipal levels. We can thus conceive permanent residence as a form of legal citizenship in potentia as it gives its possessors most of the rights and duties commonly associated with Canadian citizenship. However, it must be said that permanent residence is a status which, to use Macklin's (2007) terminology, is a lot less "hefty" than that of formal legal citizenship as it pertains to electoral participation, access to employment, and of the absolute right to remain on the Canadian territory. In fact, a permanent resident can neither vote nor run for political office. He or she cannot hold certain jobs that have a high-level security clearance requirement. Finally, if a permanent resident is convicted of a "serious criminal offence," he or she cannot remain in Canada.
} 
along the way in order to constitute a particular case of refugee resettlement. The work of production and organization (assemblage) of the various texts that constitute the case is done by various people whose work is also textually mediated. This other trail happens in places where the refugees don't go. It happens in the "backstage" of refugee resettlement i.e. in the offices of employees of various international organizations (e.g. UNHCR and IOM) and on the desks of different government agencies (e.g. Canadian Visa Office, CIC National Head Quarter, Service de Sélection humanitaire (SSH), Direction régionale du $M I C C$ ) and community organizations. This trail exists through the various texts (e.g. forms, interview notes, medical report, photos, etc.) that link these various places through time and space. It is the replicability of these texts in material form (paper) and virtual form (i.e. in and between computers) that allows the production of refugee resettlement. What links these different places is thus "the case" which is an assemblage of different texts that are themselves the result of a work of conversion of the actual experiences of 'refugeeness' of actual people into an institutionally actionable form. Darville (1995) uses the term 'textualization' to refer to such a conversion process.

\subsection{Textualization and Regulatory Frames in Refugee Resettlement}

The "writing up" of people's experiences into organizational processes is a general feature of institutions (Darville, 1995). According to Smith (2005) one of the coordinating functions of institutions is the tailoring of institutional representation:

People's actualities become a resource on which work is done to extract formalized and highly restricted representations. Extraction procedures may involve the completion of a form by a nonemployee; it may be a line of questioning by an institutional representative designed to fill the fields on her or his computer monitor or to produce a report for which she or he is accountable. In all cases, the representation is designed by the conceptual organization of an institutional discourse to which the actuality it represents must be fitted. (p.186) 
The institutional process of refugee resettlement involves this kind of process. As soon as someone enters an UNHCR field office in order to be identified as a convention refugee he or she enters into a process of textualization. In fact, the UNHCR agent responsible for the work of translating the experience of the person in front of him or her performs a particular form of work that consists of selecting certain aspects of the person's narrative so as to match it with (or demonstrate that it does not fit) the definition of the UN Convention. As we have seen in Chapter 3, once someone has been identified as a convention refugee, different scenarios may occur. One of them, which is of interest in this dissertation, is resettlement to a third country. In the case of resettlement a UNHCR resettlement officer also engages in the work of translating the experience of the convention refugee into a textual form (Resettlement Registration Form (RRF)) by selecting parts of the refugee's narrative in order to fill out the different fields in the form.

When the case is referred to Canada, a Visa officer will once again interview the convention refugee and translate his or her experience into an institutionally actionable form i.e. in a form that then allows for the work-text-work sequences of refugee resettlement in Canada.

In order to perform the work of textualization, the different people working within the institutional organization of refugee resettlement have to rely on what Smith (2005) has called 'regulatory frames'. This conceptual device refers to the "discursive procedures that organize how something is to be interpreted" (p.227). As she puts it:

In the process of constructing a factual account on institutional terms, some aspects of lived actuality get picked out and worked up as an event, a state-of-affairs representation of a person, or the like. The shaping of facts, news, information, cases, and other forms of knowledge is circular in this sense: frames govern the selection of what will be recorded, observed, described, and so on. In some institutional settings, they are specified as categories used at the front line in the work of interrogation; they are built into the technologically refined sets of questions or ratings [...]. (p.191) 
Through the resettlement process different regulatory frames shape the work of textualization at different moments. For instance, the UN Convention provides the different criteria that have to be used in order to determine refugee status. It therefore regulates the 'reading' of the refugee's narrative in a way that permits (or not) the labeling of one as a 'convention refugee'. ${ }^{26}$ In the case of resettlement, the UNHCR Resettlement Handbook informs the filling out of the RRF by the resettlement officer. ${ }^{27}$ At the federal and provincial level, other regulatory frames enter into play. These include the IRPA, the Québec-Canada Accord, the Loi sur l'Immigration au Québec (LIQ), Annual Report to Parliament on Immigration (i.e. Canada's immigration levels plan), and the Plan d'immigration du Québec (i.e. Québec's immigration levels plan). Each of these texts is located in a particular place within the intertextual hierarchy coordinating refugee resettlement from the determination of the convention refugee status by a UNHCR protection staff member to the selection of GARs by a Canadian visa office and ultimately to the resettlement of these GARs in Gatineau.

Of course, an institutional ethnography of these different work processes could provide a mapping of such an intertextual hierarchy in a way that could illuminate how refugee resettlement is organized as it is. This, however, is well beyond the scope of this thesis. What is important to highlight here is that the different textualization work processes are essential for refugee resettlement for the same reasons that they constitute an essential component of institutions in general:

\footnotetext{
${ }^{26}$ For a discussion on the labelling of refugees see Zetter $(1991,2007)$.

${ }^{27}$ In fact, the very categories of the UNHCR Resettlement Handbook are inscribed in the RRF so that the process of translating the account of the convention refugee into a textual account is shaped not only by the resettlement officer's knowledge of the institutional categories but also, and perhaps most directly, by the format and the content of the RRF.
} 
One is that they transform the local and particular into the generalized forms in which they become recognizable and accountable across the local settings of institutional work; two, the objectification of institutional realities overrides individual perspectives; three, the translation of the actual into the institutional is an essential step in making the actual actionable institutionally (Smith, 2005, p. 186).

In short, we can say that refugee resettlement as an event is the result of the coupling of the embodied experience of refugeeness and resettlement as lived by the refugees themselves (see Chapter 4) with the textualized version of that experience (i.e. "the case") happening elsewhere in places where the refugee, as an embodied subject, never is and through the work of people he or she does not know. At the 'end point' of this process, however, the physical and the textual presences of the GARs converge and constitute the matter with which the resettlement workers work. What follows is a detailed description of the work of APO staff members from the moment they receive a 'case' up to the moment the GARs have moved into their new home. It is preceded by a brief discussion of the ways in which APO staff members talk and think about their work.

\subsection{How Resettlement Workers Think About Their Work: Institutional Capture}

One of the things that emerge from the interviews I conducted with resettlement workers is that they all used the same frame in order to describe the various aspects of their work with GARs. In fact, the APO staff members conceive their work as being divided into three phases: welcoming, resettling, and integrating (accueil, installation, integration). What is of interest here for an institutional ethnographer is that this conceptual division of their work coincides with the funding process described in the previous chapter. In fact the different funding programs that allows APO to operate, conceptually organize the work around these three 'distinct' phases. So for instance the PANA volet 2 funds the welcoming of GARs at the point of arrival (usually the Ottawa 
bus station) and the MICC, through a service agreement with APO, pays for the transport of GARs to their temporary housing accommodation (which is paid, for the first 5 days, by the MICC through its PAIR). PANA Volet 2 also funds the resettling phase that consists among other things in moving the GARs into their new home and assisting them in subscribing to all the government programs for which they are eligible. Finally, the PANA (Volet 1 ) funds the integrating phase by funding certain activities such as information sessions on housing, taxes, education system, Québec society, and the legal system that APO organizes for its clients.

From the standpoint of refugees these divisions are neither quite visible nor important. Nowhere in the interviews did my GAR informants refer to the categories used by the resettlement workers when talking about their work. What matters to my GAR informants, however, was that APO staff helped them as they began a new life in Gatineau. Therefore, my resettlement worker informants' conceptual understanding of their work does not emerge from their everyday work with GARs. Rather, it is located in the institutional discourse of refugee resettlement. More precisely, this conceptual division of labour is (re)produced by the funding process of APO which is itself the product of a complex of relations which involve not only other community organizations (through TCRI for instance) but also the MICC, and other provincial and federal ministries as well as knowledge produced by migration scholars and policy experts. By referring to their work in terms of the categories inscribed in the PANA, the resettlement workers are trapped in what institutional ethnographers call institutional capture i.e. a "discursive practice, regulated by the institutional procedure of text-reader conversations, 
through which institutional discourse overrides and reconstructs experiential talk and writing" (Smith, 2005, p. 119). ${ }^{28}$

Institutional capture, however, is never complete. By this I mean that by talking about their work, resettlement workers move back and forth between the institutional discourse and their embodied experience. This allows us to contrast the institutional account of refugee resettlement with the experiential account of resettlement workers. In fact, the resettlement of GARs in Gatineau is far from being an unproblematic process.

\subsection{The Work(s) of Resettlement Workers}

NAT: activating the local organization of resettlement.

Although the PANA describes the "welcoming" phase by referring to the reception of GARs at their point of arrival, the actual work of the resettlement workers starts with the Notification of Arrival Transmission (NAT). This document indicates that a group of GARs (usually a family) have been selected by the Québec government and are destined for Gatineau. Each NAT contains the following information: the point of origin; the port of entry; the date of arrival; the flight details; the Destination Matching Request (DMR) number; final destination (for principal applicant (PA) only); family number before each PA (each separate family unit is numbered); person number for PA and accompanying dependents (each person on NAT is numbered consecutively); the visa office file number of the PA; surname (within brackets); given names; date of birth; sex; country of nationality; relationship to PA; language(s) spoken; visa or temporary resident

\footnotetext{
${ }^{28}$ The conceptual understanding of the three phases of the work or resettlement workers is not only present in the accounts of the APO staff members, it is also inscribed everywhere in the textual productions of the APO. For instance we can find in the various documents handed to the APO members at the last Annual General Meeting (e.g. the activity report and the plan of action for the year 2011-2012) the use of categories imported directly from the PANA.
} 
permit serial number; immigrant category; special program code; CSQ number; and special needs notes (CIC, 2010). The NAT, which is faxed to APO by an agent of Immigration-Québec - Direction régionale de l'Outaouais, de l'Abitibi-Témiscamingue et $d u$ Nord-du-Québec, is attached to a document from the MICC which gives the date of the information session (it is usually the day after the arrival).

The NAT is taken by the director of APO who then allocates the case to a resettlement worker. The director makes this decision after he had consulted the working team. The cases are usually given successively to each resettlement workers but criteria such as the workload of staff members or the language spoken by the GARs to be resettled are taken into account. ${ }^{29}$

Once a resettlement worker has been allocated to a case, he or she reads the NAT in order to get an idea of the family composition. This information allows the resettlement worker to start a search for housing ${ }^{30}$ and to book one or two vehicles for the day of the GARs' arrival. If the resettlement worker does not speak the language(s) spoken by the GARs, he or she will look for an interpreter in the APO's "banque d'interprètes". The resettlement worker also reads the NAT in order to see if there are any children that need to be registered at school or if there is any mention of infectious or chronic diseases for which one or many GARs will need to see a health care professional upon arrival. ${ }^{31}$

\footnotetext{
${ }^{29}$ The process of attribution of cases is in fact intimately linked to the languages spoken by the staff members. The fact that the hiring process of APO favors people who speak more than one language is itself linked to funding which is not sufficiently generous to allow for the hiring of interpreters on a regular basis. The resettlement workers are thus being asked to do the work of interpreters for free. This also serves a time management function since resettling work is easier and faster when no interpreter is needed.

${ }^{30}$ As we will see later in this chapter, this task is not as straightforward as it may seem and represents one of the biggest challenges for the APO staff.
} 
The resettlement worker therefore "activates" the NAT by translating its reading into a work sequence that produces the final stage (or end point) of refugee resettlement. ${ }^{32}$ This translation (from text to work), however, does not happen without difficulties.

\section{"Chaque jour c'est plus difficile": finding housing for GARs.}

As we have seen, it is the reading of the NAT by the resettlement worker that activates the sequence of actions that produce resettlement in Gatineau. One of the works performed by the resettlement worker that results from his or her reading of the NAT is the search for housing. In the past, the agreement between APO and the MICC mentioned that resettlement workers had to provide GARs with a choice of at least three apartments. After having visited them, the GARs had to choose the one that best suited them ${ }^{33}$. However, due to some the important challenges resettlement workers are facing nowadays regarding the search for housing, the obligation to provide GARs with three choices of apartment became merely a suggestion.

In fact the apparently simple task of finding apartments to GARs constitutes one of the biggest challenges for resettlement workers.

As $V$ puts it:

${ }^{31}$ As we will also see later, the issue of access to health care is another important challenge for the APO staff.

${ }^{32}$ The resettlement worker uses a working document entitled (Gestion de Dossier), which orients his or her work. This document contains the different steps necessary for the successful resettlement of GARs as well as general information such as the names, date of birth, country of origin, marital status, sex, SIN, Health Insurance Number, File number at Centre Local d'Emploi, address, phone number, date of arrival, etc. This document has been designed by the APO staff in a way that reflects the regulatory frame of the Purchase of Service agreement that links APO with the MICC in the provision of resettlement services in different ways. First it describes all the services APO is supposed to provide to GARs and second it keeps track of all the information necessary to compile the statistics that the funding agency (MICC) requires as a condition for funding (accountability mechanism). (See chapter 5).

${ }^{33}$ It is important to note here that this emphasis on 'choice' is an important feature of the advanced liberal rationality depicted by Lippert (1998) in his article on refugee resettlement in Canada. 
La réalité que l'on vit dernièrement c'est qu'il y a une pénurie de logement et c'est de plus en plus difficile de trouver des logements surtout des logements à prix modique et des logements où les propriétaires sont disposés à louer aux immigrant.

\section{Vacancy Rates and apartment rents}

In Gatineau, the availability of affordable housing, ${ }^{34}$ and especially for large apartments, has dramatically decreased over the last decade. This had an important impact on the apartment rents. In fact, the average rent in Gatineau for a two bedroom apartment went from $\$ 495 /$ month in 2000 to $\$ 711 /$ month in 2010 (Logemen'Occupe, 2011). As of April 2011 the average rent for three bedroom apartments was $\$ 807 /$ month (CMHC, Spring 2011).

As we have seen in Chapter 2, one of the things that characterize GARs is that they usually arrive with large families. This is especially true for African GARs. ${ }^{35}$ As B argues:

Souvent à ce moment là c'est difficile pour les famille nombreuses...on n'arrive pas à trouver...des familles Africaine nombreuses...comme au mois de décembre nous avons accueilli une famille de 21 personnes... [...] Souvent c 'est 7 ou 8 personnes.

Given the fact that the vacancy rate for three-bedroom apartments in Gatineau is only $2 \%$ (CMHC, Spring 2011), resettlement workers sometimes have to split families into several apartments. This is what happened with the Bembas who are twelve family members. In fact, because of the unavailability of large apartments, $V$ had to split the Bembas into three groups that could fit three two-bedroom apartments. Fortunately, the three apartments $V$ found were in the same neighbourhood.

\footnotetext{
${ }^{34}$ According to CMHC's website, "The cost of adequate shelter should not exceed $30 \%$ of household income. Housing which costs less than this is considered affordable".

${ }^{35}$ And this is true not only in Québec but also elsewhere in Canada (See Francis, 2009).
} 
Moreover, GARs are burdened with a debt (transportation loans) and rely mostly on social assistance for income. Therefore, GARs cannot afford most of the apartments on the Gatineau rental market i.e. high rent apartments (Logemen'Occupe, 2011). An important aspect of the resettlement workers' work is thus to find decent apartments that GARs can afford. Unfortunately, low rent apartments are sometimes insalubrious and can be harmful to tenants' health. GARs constitute a vulnerable population as it pertains to unhealthy dwellings (See for instance Lafortune, 2010). Resettlement workers know this and try their best to find proper housing for GARs. However, they do not always succeed:

C: Parfois nous nous retrouvons dans le trouble parce qu'on doit mettre le monde dans des appartements qui ne sont pas vraiment décent...en mauvaises conditions. Alors c'est très difficile. On tente de faire le mieux toujours mais la situation c'est chaque jours plus difficile.

\section{Reluctant landlords}

Another important challenge that resettlement workers face when looking for housing for GARs is the reluctance of some landlords to rent to immigrants in general and to GARs in particular:

I: Souvent il y a des appartements à louer et des maisons à louer pour les grosses familles mais les propriétaires demandes un cosignataire, demandent des références, demandent un emploi. Alors que dans le cas des réfugiés c'est irréaliste de penser que ces gens-là qui viennent d'arriver ont déjà des références, des consignataires et un emploi.

Refusing to rent to someone because of his race, ethnicity, political affiliation, social class, gender, etc. constitutes an act of discrimination in virtue of the Charte des droits et libertés de la personne du Québec. Therefore, a landlord cannot refuse to rent to anyone on the basis of any of the discrimination motives enumerated in that charter.

Some landlords, however, have found a way to work the system. 
Credit record searches and background checks are common instruments used by landlords to screen prospective tenants. For GARs, however, the use of such instruments prevents them from renting an apartment. In fact, GARs, do no have any credit records nor referrals for the background checks. They have never rented an apartment and more often than not, they do not know anybody that can so-sign the lease with them.

Resettlement workers have to inform landlords about the peculiar situation of GARs and convince them to accept GARs as tenants. APO staff members have succeeded over the years at building a network of landlords with whom they make business on a daily basis. This network, however, is fragile and APO staff members emphasise the importance of respecting the lease as well as the different laws and rules they teach GARs about housing in Québec. ${ }^{36}$

\section{Negotiating cultural/religious practices as they pertain to housing}

Working in a multicultural environment usually involves some sort of negotiation of different practices and beliefs. Refugee resettlement is no exception and resettlement workers' search for housing is sometimes shaped by them:

$V:$ Exceptionellement encore il y a des cas où pour des raisons religieuses les gens ne sont pas prêt à prendre un logement. Comme par exemple il faut que le soleil sortent à gauche ou à droite pour faire la prière ou je ne sais pas quoi...On essaye toujours d'accommoder les gens...C'est sur que ça ne facilite pas notre tâche parce qu'il arrive qu'on trouve de bon logement mais que le soleil sorte de l'autre côté...alors

$[\ldots]$

\section{Me : Ok. Et dans ce temps-là vous faites quoi?}

$V$ : Il faut trouver un autre logement c'est ça. On essaye quand même de voir... Il $y$ a des gens qui sont quand même raisonnables mais il y a d'autres gens qui sont

\footnotetext{
${ }^{36}$ During my fieldwork, three major landlords of the APO network started to automatically ask for credit records and background checks thus making it impossible for GARs to rent apartments from them.
} 
vraiment fermés. Nous avons vécus un cas où la personne ne voulais pas s'installer un Jeudi parce que ce jours là en particulier il devait faire...je ne sais pas quoi...une prière ou quelque chose comme ça. Alors à ce moment là il faut des fois négocier beaucoup avec les gens et dire: "Écoute là...on ne peut pas attendre une journée là"

What $\mathrm{V}$ states here suggests that there are some beliefs/practices that he can accommodate and others that he cannot. This is in part determined by how these beliefs/practices impinge on the resettlement process and on the corresponding work performed by the resettlement worker. This depicts the paradoxical nature of the resettlement worker's work: on the one hand the resettlement worker cares, comforts, accommodates, helps and on the other he imposes, decides and presses the GAR. In regards to housing, this paradox emerges out of the fact that the resettlement worker is at the same time face to face with the newly arrived GAR who is needy, tired, disoriented, etc. and aware of the fact that finding housing is a pressing and critical moment in the local resettlement process.

\section{Finding Housing as a 'moment'}

In regard to the overall work of resettlement workers, housing is not an end in itself; it is a "moment" in a sequence of actions:

$C$ : Parce que le problème de logement c'est que l'on a besoin d'une adresse pour avoir n'importe quel service... l'inscription à l'école ce n'est pas possible s'il y n'y a pas une adresse. Partout où l'on va nous allons avoir besoin d'une adresse.

Finding housing is thus certainly a priority for APO staff members not only because it will provide GARs with a new home but also because it will in turn allows for the accomplishment of the other work processes involved in refugee resettlement. One way to illustrate this is to describe the transition from temporary to permanent housing and how that transition is coordinated by extra-local relations. 


\section{Temporary housing}

After having welcomed the GARs at the bus station, the resettlement worker drives them to the temporary housing previously inscribed in the NAT. In Gatineau, there are two temporary housing facilities recognized by the MICC. One is the Auberge operated by APO (see Chapter 5) and the other one is Motel Montcalm. Each venue has a purchase of service agreement with the MICC that frames the provision of temporary housing service to GARs. ${ }^{37}$

Through the Programme d'Accueil et d'Installation des Réfugiés (PAIR) the MICC provides, among other things, temporary housing to GARs for the first five days of their arrival. In fact, the MICC, pays up to five days of stay at l'Auberge and the Motel Montcalm for GARs. The rationale behind this is that five days after their arrival, GARs will have had their first social assistance check and will therefore be capable of paying for their housing. If after that period the GARs did not move into their permanent home, they will need to pay a certain amount to temporary housing venues ( $\$ 12$ per adult and $\$ 6$ per child per day).

This has the effect of putting pressure on resettlement workers to find housing as soon as possible after the arrival of the GARs so that the latter will not pay for temporary housing. But as we have shown above, finding housing in Gatineau is not easy and sometimes requires more than five days to do so. When this is the case, the APO staff members experience a certain discomfort vis-à-vis GARs:

\footnotetext{
${ }^{37}$ The criteria used to decide to bring the GARs to APO's Auberge or alternatively, to Motel Montcalm, for temporary housing are not clear. The MICC representative I interviewed mentioned the notion of 'fairness' ... "APO can't have all the GARs for temporary housing...this would be like conflict of interest". The APO staff members, however, think it is the number of people per case that determines to which temporary housing facility the GARs are being sent.
} 
$B$ : Il y en a qui était au motel et que ça nous a pris...je pense 2 semaines...ça leur à couté dans les $\$ 700 . .$. il n'était pas content...

Me : Non j’imagine...Et vous en même temps vous ne voulez pas ça...

$B$ : Non...on est mal à l'aise...c 'est ça...c'est pour quoi on veut faire le plus tôt possible... de trouver un appartement le plus tôt possible...pour éviter à ces genslà de payer de l'argent.

It is not only the expediency with which the resettlement worker will find affordable and/or decent housing for GARs that will ensure their well-being and successful resettlement, it is also its very location.

\section{Housing and access to services}

To resettle refugees means to welcome a particular kind of immigrant. GARs arrive in Gatineau with all sorts of needs: financial, physical, mental, educational, etc. There exist several institutions and organizations in Gatineau that can address different needs such as schools, employment agencies, medical clinics, etc. The major problem for GARs (and for resettlement workers) is that these resources are not evenly distributed throughout Gatineau. ${ }^{38}$ This means for the resettlement worker that depending on the refugee's needs (usually determined reading the NAT) he/she will attempt to find an apartment in a sector where it is most likely that the GARs will receive the necessary services.

Me : Donc il n'existe pas de service psychosocial adapté aux situations interculturel...il n'existe pas ça ici?...donc vous n'êtes pas en lien avec le CLSC?

$C$ : Nous sommes en lien avec le CLSC mais...Nous sommes dans la grande ville de Gatineau mais le CLSC de Hull ce n'est pas le CLSC de Gatineau...Au CLSC de Hull il y a une clinique des immigrants...le Mardi après-midi seulement [rires]...Au moins il y à ça... à Gatineau rien! À Aylmer Rien! Alors si tu trouves

${ }^{38}$ Gatineau is the result of a municipal amalgamation that encompassed the former cities of Aylmer, Buckingham, Hull, Masson-Angers, and Gatineau. It has a population of about 260000 people and it has a territory of $342 \mathrm{~km}^{2}$. 
un appartement à Gatineau ou à Aylmer pour une famille ça veut dire qu'ils n'auront pas de services au CLSC...

Me : Donc en étant conscient de ça est-ce que vous priorisez Hull dans la recherche de logement?

$C:$ Si on trouve oui.

Me: Donc à loyer égal, vous allez prendre Hull avant Gatineau ou Aylmer?

C: Oui. Bien sur...mais les gros propriétaires sont surtout à Gatineau. Alors c'est compliqué ça...Et je pense que ça c'est le plus difficile mais...on a des difficultés dans la grande ville de Gatineau par exemple dans les écoles. Il y a seulement des classes d'accueil pour les allophones à Hull et à Gatineau.

\section{Me : Dans 2 écoles?}

$C:$ À Hull il y a deux classes d'accueil dans 2 écoles primaires et une dans école secondaire. Dans Gatineau c'est un, un. Et Aylmer il n'y en a pas. Et c 'est une des raisons pour lesquelles on ne cherche pas de logement à Aylmer...Parce que c'est très difficile pour le monde qui viennent d'arriver et qui n'ont pas de voiture alors c'est compliqué. Alors ça complique la situation. Ce n'est pas que c'est impossible... si tu demeure là-bas il vont te fournir la passe pour l'autobus mais la situation c'est que le service de transport c'est très bon mais ce n'est pas fréquent...

Me : Oui...c'est parfait pour les fonctionnaires mais pas pour le reste des gens...

$C:$ Exactement!

This interview extract raises many issues regarding the location of the GARs' permanent housing and its relation the access to various services. It shows first that one's access to specific services is not equally distributed in Gatineau and that the resettlement workers need to take this into account when looking for housing. This consequently leads to an uneven distribution of GARs throughout Gatineau. This situation is accentuated by the fact that the public transportation schedule in Gatineau is modeled on the federal public services office schedule and that it does not well serve the whole city throughout 
the day. ${ }^{39}$ What $\mathrm{C}$ also depicts is what I call the 'tyranny of the postal code'. In fact, some services are accessible only for those who live in a certain area. The immigrant clinic for instance is part of the CLSC de Hull. That means that if a GAR lives in another sector of the city (e.g. Aylmer or Gatineau) he/she will not have access to the immigrant clinic. Another important barrier to the immigrant clinic is the fact that those who speak French or English cannot benefit from the clinic services. This situation adds to the already difficult task of finding healthcare services in a region that experiences a marked shortage of such services (Mercier, 2011) and sometimes pushes resettlement workers to lie about a GAR's language in order to book an appointment :

$B:$ Quand on voit que c'est quelqu'un qui est vraiment malade...parce qu'on reçoit réellement des gens qui sont malades... on va encore tricher. On va dire qu'ils ne parlent pas français [...] Il y a des gens que j'ai déjà accompagné et je me suis fait passé pour une interprète parce qu'elle était très malade...elle était enceinte et elle avait besoin d'un médecin...Ils nous obligent à mentir. ${ }^{40}$

Schools are also attributed through postal code and not all schools have integration classes for allophones. In light of all these barriers, GARs' permanent housing location is of tremendous importance for their future well-being.

In sum, all sorts of extra-local relations mediate the work of finding housing for GARs. Some of these relations are exogenous to the resettlement process and affects the work of resettlement workers 'from outside': the apartment rental market in Gatineau, the reluctance of landlords to rent to immigrants or visible minorities, or the cultural/religious beliefs and practices of GARs for instance. Other relations, however, emanate from the

\footnotetext{
${ }^{39}$ In fact, there is an intensive scheduling of buses in the morning that depart from the city's periphery and head towards its center (i.e. Portage Place) and Ottawa. There is then a lull in the late morning until mid-afternoon. Then, there is another massive influx of buses that depart of the center of the city and bring people back into the periphery. It is therefore very difficult (and terribly long) to use public transportation in the opposite direction and outside the rush hours.
}

${ }^{40}$ For a discussion on the barriers to care for GAR in Canada see McKeary and Newbold (2010). 
resettlement process itself. These endogenous relations include the GARs' income and their transportation debts, the State funding of temporary housing to GARs (PAIR) and its relation to service providers (Auberge, Motel Montcalm, , the different needs of GARs and the issue of access to the corresponding services, etc. These endogenous relations coordinate the work of resettlement workers according to different discourses: one is the discourse of humanitarianism (at least in its humanist form). It emphasizes the caring dimension of resettlement and is (re)produced through the "caring work" of APO staff members i.e. their inclination towards finding decent housing in an appropriate location for the well-being of GARs. The second one is the advanced liberal discourse that emphasizes efficiency, choice, independence, and the reliance on community organizations rather than on the State. It is (re)produced through the work of a resettlement worker as he/she for instance, prioritizes efficiency and choice over accommodation of cultural practices. These two discourses are not only shaping the work of finding housing but permeate all the works of resettlement workers.

\section{Reception of $G A R s$}

The reception of the NAT triggers a particular sequence of action that involves, among other things, finding housing for GARs. However, there is not much a resettlement worker can do without the actual presence of the GARs whose names are inscribed on the

NAT. As one informant told me,

Me: Donc une fois que tu as reçu sur ton bureau le fax qu'est-ce que tu fais avec?

C: Moi je prépare une fiche sur la famille. Mais malheureusement ce n'est pas toute l'information que j'ai avant qu'il arrive. C'est seulement lorsqu'il arrive que j'ai plus d'information

Me: $\boldsymbol{O k}$

C: Quand on a fait l'accueil alors je vais en profiter pour m'informer d'avantage 
sur c'est quoi la situation et compléter ma fiche.

Another resettlement worker offers a similar answer:

Me : Quelque chose que j'aimerais savoir c'est que se passe-t-il avant l'arrivé des RPCE? Que se passe-t-il à partir du moment que vous recevez le fax? Que devez-vous faire concrètement...étape par étape?

$V$ : En fait si la personne n'est pas ici physiquement on ne peut rien faire. La seule chose qu'on fait c'est qu'on se prépare à l'avance... on va appeler des propriétaires : "écoutes, je reçoit une famille jeudi...est-ce que je peux venir vendredi matin visiter ton appartement?" ... "Non vendredi je ne peux pas ça va être Lundi.. "...Alors c'est ça... On prépare un peu pour avoir une idée... Mais on ne peut rien faire, aucun document si la personne n'est pas physiquement ici...pour une raison simple on a besoin des documents d'immigration pour faire quoi que ce soit...

It is thus not only the physical presence of the GARs as such that allows the resettlement worker to pursue his or her tasks beyond what the NAT allows them to do, it is the material presence of the various documents the GARs bring with them. As we will see later, an important feature of the work of the APO staff member is to coordinate the 'textual birth' of the newly arrived GAR. But for the moment let us now look at the reception of GARs.

GARs whose final destination is Gatineau usually arrive by bus at the Ottawa Central Station. ${ }^{41}$ This is where the resettlement worker in charge of the case meets the GARs and greets them. The GARs at the bus station are recognizable primarily because of the white and blue bag they carry on:

\section{Me: Et comment faites-vous pour les reconnaitre?}

C: Pour les reconnaitre? C'est vrai on a les noms mais c'est difficile parce qu'il y a plusieurs...C'est parce qu'ils ont un sac...ils ont un sac spécifique de l'OIM. Alors on les reconnais par ce sac là. Ils ont la consigne de toujours garder leur sac partout où ils passent... à l'aéroport, on les reconnait par ce sac là.

\footnotetext{
${ }^{41}$ On rare occasions, in the case of a large family for instance, a group of GARs can arrive directly at the APO's Auberge or at the Motel Montcalm by charter bus. This was the case for the Bembas who were 12 family members arriving at the same time.
} 
This bag, which bears the logo of the IOM, functions as a text that connects (both materially and symbolically) the resettlement process abroad with the local provision of resettlement services. But it is not only the bag itself that perform this function; it is also what it contains. In fact the IOM bag contains all the documents that the GAR and the resettlement worker need for 'accomplishing' resettlement. These documents are the (1) Single Journey Document for Resettlement to Canada (IMM5485), (2) the Interim Federal Health Program (IMM1442), (3) the Certificat de Sélection du Québec (CSQ), and (4) the Confirmation of Permanent Residence (IMM5292).

These documents "are" the case. It is these documents, and not the actual GAR, that have the power to activate the sequences of actions that leads to his or her resettlement. We can thus imagine that the bag and its contents are extremely precious. As J, a GARs from Togo, points out:

$J$ : Ils vous conseil de ne pas laisser le sac. Même à l'orientation on parle de ça. Ce sac là c'est vraiment toute ta vie. Parce il y a des gens qui disent que des gens volent ça. Si on te fait ça tu ne peux plus continuer...

The IOM bag thus contains the GAR's "whole life" or at least its textual form which is actionable institutionally and which will allow the resettlement process to occur.

The greeting of GARs by the resettlement worker is also an important feature of the reception process. It has the purpose of both introducing the resettlement worker (and APO) to the GARs and providing them with comfort and reassurance:

B: On sait comment leur parler...C'est-à-dire que bon...l'autobus arrive et nous on sort quand même qu'il fasse froid ou pas. On sort, et on va les accueillir vraiment à la descente et on va juste leur dire : "Bonjour » bienvenue au Canada » et juste parler... "Avez-vous fait un bon voyage? » des choses comme ça. Juste pour voir si tout le monde va bien et tout ça. [...] Alors ils sont rassurés souvent quand il voit que quelqu'un parle la langue qui est là et qui les attends. [...] c'est encore plus sécurisant pour eux quand ils voient que c'est une personne de son pays ou du même continent qui les accueil. 
Given the fact that most APO staff members are themselves immigrants (and refugees) it is not surprising to see that caring is an important dimension of their work. ${ }^{42}$

Once at the temporary housing facility, the resettlement worker provides some information to the GARs:

$V$ : En arrivant, dépendamment de l'heure d'arrivée, on fait aussi une petit réunion avec les gens juste pour expliquer comment fonctionne l'auberge, à quelle heure ils vont recevoir la nourriture, et en général on donne des informations, mais de façon très ponctuelle parce que les gens sont fatigue. Des fois ils ont fait plus de 18 heures de vol, les enfants sont fatigues, dorment, etc. Et on explique un peu ce qui va se passer le lendemain au ministère. Alors quand les gens arrivent au ministère, ils sont informés des étapes à suivre. Alors on explique qu'ils vont être loge et nourri pendant cinq jours. Après cinq jours, si on n'arrive pas à trouver un logement les gens doivent faire une petite contribution de $12 \$$ par adulte et $6 \$$ par enfant par jours.

B : Oui c'est moi qui fais la session d'information. Alors la même chose...en arrivant on commence par présenter la dame qui fait la cuisine en bas pour les rassurés et leur dire: "Voilà, vous n'êtes pas seuls, quelqu'un va s'occuper de vous tout au long de votre séjour à l'auberge ". Alors ils sont déjà rassurés. À ce moment là on leur montre leur chambre et ils déposent leurs bagages. Ensuite je les invite à venir pour une petite session d'information. On n'explique pas beaucoup parce qu'ils sont très fatigués quand ils arrivent. Des fois c'est 2 jours de voyage...ils sont vraiment fatigué. La première chose c'est de s'assurer que personne n'est malade ou bien si les enfants vont bien et tout ça. Si tout va bien a ce moment là on leur donne une petite information juste pour leur dire : "Voilà vous êtes au Motel c'est temporaire on va vous trouver un logement " et pour leur dire: "Voilà demain matin vous allez avoir une session d'information au MICC ». [...] On leur explique les règlements de l'auberge. On leur montre la salle de bain. Souvent il faut...comme les africains qui viennent des camps de réfugiés, ils n'ont jamais connu des sièges à la salle de bain...ou bien l'eau chaude...il y a plein de chose à expliquer... Les couches pour les enfants...expliquer comment ils peuvent protéger le matelas si les enfants font pipi au lit...plein de choses quand même...Pour les réfugiés qui viennent d'Afrique c'est beaucoup plus que les autres...C'est beaucoup beaucoup plus que les autres...

This is what we can refer to as the 'teaching work' of resettlement workers. This type of work links and, is informed by, both the 'caring' and 'coordinating' dimension of

\footnotetext{
${ }^{42}$ This situation is typical to most resettlement workers in the province of Québec (Saillant, 2007)
} 
resettling work. It provides reassurance to GARs through the communication of information about the organization and the unfolding of their stay at the temporary housing facility, which is informed by the resettlement worker's knowledge of the institutional organization of resettlement both locally and extra-locally.

Teaching work also involves the communication of information necessary for the smooth accomplishment of everyday tasks. It involves, for instance, teaching about the toilet seat or a how the shower works or about how to put sheets on a bed. The teaching workload of resettlement workers, however, depends on the GARs' background and experiences. As B mentions above, resettling African refugees tend to involve more teaching work. In fact most African GARs resettled in Gatineau have for the most part lived in refugee camps for years before coming to Canada. And as we have seen in chapter 4, the life conditions in the camps are sometimes far from what GARs experience once in Canada.

The cultural origins of the GARs also shape the work of resettlement workers in another important way. In fact, one feature of resettling work at the temporary housing facility is the negotiation of different eating practices. As B puts it:

B: C'est ça. C'est ça. Et on s'assure que s'il y a des musulmans, on s'assure qu'on puisse acheter la viande qui leur convient...la viande Halal et tout ça... On prend soins de ça....ou s'il y a quelqu'un qui à besoin d'une diète spéciale ou quelque chose comme ça. [...] s'il y a des bébés, on s'assure qu'il y ait de la nourriture pour bébé. Quelqu'un qui est végétarien...enfin on s'assure de tout.

This aspect of resettling work is easier to accomplish when the GARs are temporarily housed at the Auberge since the APO staff member have more direct access to its functioning. ${ }^{43}$

\footnotetext{
${ }^{43}$ This can be said of the resettling work in general. For the APO staff members, it is easier and more efficient to work with GARs temporary housed at the Auberge.
} 
Teaching work is not only performed at the bus station or at the temporary housing facility, the resettlement worker performs it throughout the whole resettlement process. It results from the face-to-face interaction with GARs and from an ongoing evaluation of what needs to be taught as the resettlement process occurs. This interactional dimension of the resettlement worker's work, however, is but a fraction of his/her overall work. In fact, the resettling of GARs also involves 'textual labour'.

\section{Textual Labour}

When the resettlement worker picks up the documents contained in the GARs' IOM bags he/she initiates a textual form of labour that will ultimately result in the 'textual birth' of GARs as a particular kind of members of Canadian society. Before the physical presence of GARs on the Canadian territory, GARs' cases have been textually constituted and activated through the work of different people so as to allow for their legal and institutional reception in their city final destination. The physical presence of GARs in Canada is thus textually legitimized through different documents. The GARs have some of these documents in their possession when they arrive in Gatineau and one of the types of work performed by the APO staff members is to institutionally activate these documents so as to (re)produce the inscription of GARs into different institutions. The first thing that the resettlement worker does after the reception of GARs and their instalment into the temporary housing facility, is to make several copies of the original documents that each GAR brought with them. These are the Single Journey Document for Resettlement to Canada (IMM5485), the Interim Federal Health Program (IMM1442), the Certificat de Sélection du Québec (CSQ) and the Confirmation of Permanent Residence (IMM5292). Then he/she prepares different files for different institutional inscriptions. Each file contains a photocopy of each of the four documents mentioned above as well as 
a copy of the form that it is needed for the institutional inscription. So for instance there is one file per adult GAR for the CLE with the photocopy of the four documents plus a Demande d'aide financière de dernier recours (i.e. social assistance form) as well as a Prevue de Résidence form. There is a file for the Canada Child Benefit, another one for the programme de Soutien aux enfants of the Régies des Rentes du Québec. There is also a file for the Address Notification form for the Permanent Residence Card and another one for the Régie de l'Assurance Maladie du Québec (RAMQ).

The metaphor of birth to refer to the institutional inscription of GARs into several institutions highlights the temporal dimension of refugee resettlement. After a long period of gestation (usually in the form of a prolonged exile) there is a short but intense labour that takes place to give birth to the GAR as a member of Canadian society i.e. a bearer of particular rights and entitlements. In the textual birth of GARs, the resettlement worker acts as a 'midwife' that orients the GARs in the various stages.

The textual labour done by the resettlement worker consists of a series of text-acttext sequences in which he/she takes some information that are contained in a specific texts and transposed them into another text that will be sent elsewhere and that will then be taken up by someone else that will then activate another text-act-text sequence, etc.

The work of inscription does not only involve a form of textualization (from texts to texts): it also involves the coordination of the multiple acts of inscription that constitute the textual birth of GARs. In fact, textual labour has to be done in a particular way and in relation to the other types of work performed by the resettlement worker. For instance the search for housing will usually precede the filling out of the Canada Child Benefit form because the permanent address of the GARs is needed. For social assistance, however, the Demande d'aide financière de dernier recours will be filled out as soon as the 
resettlement worker receives the GARs' official documents. He/she will put APO address and phone number in the form and will fill an Avis de Déménagement when the GARs will have sign the lease for their permanent home.

The textual labour of resettlement workers cannot be reduced to the filling out of forms. In fact, there is another dimension of the textual labour which consists of physically accompanying GARs to the various places where registration occurs. For instance, the resettlement worker will bring the GARs to a commercial photographer where a photo will be taken. The resettlement worker will then join the photo to the RAMQ form. The APO staff members also bring the GARs to the bank where he/she will open a bank account so that he/she will be able to receive government checks.

\section{Conclusion}

The work of the resettlement workers essentially consist of two elements: (1) to assist GARs in their initial resettlement in Gatineau and (2) to finalize the textual gestation of the "case" and coordinate the final stage of the institutionalization of the GARs' 'new life' as a permanent resident. The first dimension of their work is an expression of the humanitarian dimension of resettlement while the second is tributary to the legal-administrative dimension of resettlement that is discursively organized by an advanced liberal rationality (Lippert, 1998). While these two dimensions are essential to refugee resettlement, there is a difficult negotiation at play here. On a daily basis, resettlement workers have to negotiate between these two dimensions of resettlement.

In fact, the search for housing, textual labour and teaching work are performed and coordinated by the resettlement worker so as to produces the resettlement of GARs in Gatineau. These various types of work happen at different moments in the resettlement 
process and are shaped by various extra-local relations such as the apartment rental market, the organization of health care services delivery, the state funding of various aspects of resettlement, and the division of labour throughout the refugee resettlement process as a whole (i.e. from the reception of refugees in camps to their resettlement in Gatineau). The work of the APO staff members also consists in coordinating their forms of work with those of others situated elsewhere in the resettlement process and to negotiate the various demands that are imposed on the local provision of resettlement services by these extra-local relations. Conflicts and problems, however, emerge out of this negotiation and the resettlement workers are often caught between the pressing needs of GARs (and the expression of these needs during their face-to-face interactions with them) and the different constraints imposed on their work by various relations of ruling.

The feeling of increasing pressure on the resettlement workers is not only experienced by APO staff members, it is generalized across the thirteen community organizations that provide resettlement services to GARs in Québec. So much so that in October 2010, the Table de concertation des organismes au service des personnes réfugiés et immigrantes (TCRI) wrote a letter to the Deputy Minister of the MICC asking for an emergency meeting. This letter, entitled Situation critique concernant l'accueil et l'installation des réfugiés pris en charge par l'État-Demande de reunion d'urgence, stated that the PANA

[...]ne répond plus aux exigences contractuelles imposées aux organismes. L'ensemble des tâches nécessaire pour répondre minimalement aux besoins essentiels des RPCE [GARs] ne peuvent plus être déployé à cause du manqué de ressources humaines au sein des organismes mandatés. Les services offerts par les organismes communautaire qui ne sont pas couvert par le norme du PANA se multiplient de mois en mois, entre autre à cause des exigences du réseau de la santé et des services sociaux et de l'éducation envers les organismes d'accueil. 
This unbearable situation pushed the thirteen organizations to threaten the MICC to strictly apply the normative framework of the PANA and to stop providing services that are not funded. At the writing of this dissertation, the MICC provided $\$ 17,500$ to each of the thirteen organizations and invited them to participate to the consultation for the revaluation of the PANA. 


\section{Chapter 6: Conclusion}

The study of refugee resettlement is complex. This complexity stems from the fact that resettlement happens through the work of people active in many settings including international agencies, ministries, and NGOs. By casting a magnifying glass on the 'end point' of resettlement, this study has shown that the resettlement experiences of GARs are (re)produced through the work of people such as UNHCR staff, Visa officers, provincial functionaries, and APO resettlement workers. This thesis has attempted to answer two sets of questions. The first one pertains to the role refugees themselves play in the resettlement process and asks what does resettlement entail on the part of refugees? What does a refugee do as s/he goes through the resettlement process? The second set of questions that this thesis attempted to answer examines how resettlement is organized at the local level and focuses on the work performed by resettlement workers: what exactly do resettlement workers do? How do they welcome and integrate refugees in their new city?

By addressing these questions through the prism of institutional ethnography, this study of the resettlement of GARs in Gatineau, Québec has permitted an examination of how the social organization of refugee resettlement in Québec connects with the resettlement process abroad. This thesis argues that a focus on work, generously conceived, allows us to connect various settings that are usually understood as separate spheres of institutional activity. It also highlights the active participation of refugees and resettlement worker in the resettlement process as well as how their doings are coordinated through texts. IE, it is shown, allows us to take the local as a point of departure to explore the global. While Smith's generous concept of work has, to my 
knowledge, never been applied to the study of refugee resettlement, this study has demonstrated the usefulness of such a conceptual device by generating three key findings.

\subsection{Finding \#1: Refugees are at work in the resettlement process}

As we have seen in this thesis, refugees are actively participating in the resettlement process through their various 'works'. In fact, it has been argued that remembering and waiting are integral and significant characteristics of refugees' experience of resettlement. Remembering and Waiting are two forms of work that have to be exercised by GARs as they make their way through the long and winding road from exile to resettlement.

By highlighting the active dimension of refugees' experiences, this research contributes to the effort made by some scholars to demonstrate refugees' agency. Writing about the existing literature on refugees, that he considers as being mainly state-centric and burdened with a problem-solving approach, Nyers (2006) argues that

...despite the multiplicity of refugee experiences and reasons for flight, conventional analyses of the subject remain committed to a hierarchical mode of interpretation that works to efface this multiplicity. This is perhaps most evident by the striking absence of political "voice" or agency on the part of refugees in these studies. The prevailing attitude in conventional analysis of refugee movements is one that provides no place for refugees to articulate their experiences and struggles or to assert their (often collectively conceived) political agency. Refugees are silenced by the very discourse that attempts to provide solutions to their plight. (p. xiv)

But while the notion of agency put forward by Nyers here, equates primarily with struggles and resistance, this thesis has demonstrated that refugees' agency can also realize itself as a form of participation or accommodation. In fact, it has been demonstrated that refugees engage in various forms of 'work' that are necessary for resettlement to happen. In accordance with IE, the notion of agency developed in this 
thesis (through the concept of work) also served as a conceptual device that oriented us to the ways in which refugees' work coordinates with that of others.

The demonstration that refugees are already active in the resettlement process has implications for policy and invites policymakers to acknowledge the active participation of refugees in the resettlement process. In this respect, this thesis agrees with Simich (2003) who argues that GARs should have a say about the place they are being sent for resettlement. Moreover, this thesis invites policy makers to reflect on the current configuration of the resettlement process in light of the work performed by refugees themselves. For instance, knowing what the various interviewing procedures entail on the part of refugees in terms of memory work and the constant remembering of traumatic events and knowing that this could lead to mental health issues for GARs, could bring us to re-think the importance and necessity of the repetitiveness of interviews in the resettlement process.

\subsection{Finding \#2: Resettlement workers are caught between GARs and the State}

By paying attention to what resettlement workers actually do, this thesis has shown that resettlement workers' work well exceeds their 'job description'. For instance, the APO staff performs the coordination of the textualization of refugees and their registration in the various government programs. As such they act as 'midwives' and assist the refugees in their 'textual birth'. The coordination of the 'textual birth' of refugees represents a significant portion of the work performed by resettlement worker but is absent from their job description modeled on the PANA. This thesis also shows that through the accomplishment of their work, resettlement workers are caught between GARs' needs on one side and forces on which they have no control on the other (e.g. the 
rental market and the problem of access to various services in Gatineau). This situation is becoming extremely difficult and resettlement workers are afraid that they may no longer be able to properly address refugees' needs. If resettlement is to be a humanitarian enterprise, it has to exceed the shortsighted perspective of the State. In fact, if we reduced resettlement to what is actually described in the PANA it would inevitably lead to the failure of the State to protect those it has selected abroad for resettlement. Therefore the work of APO is not only to resettle refugees in Gatineau, but it is also to allow the State to fulfill its humanitarian mandate. In sum, at the same time that APO staff, through their relentless dedication, allows for the 'successful' resettlement of GARs in Gatineau, it also participates in the (re)production of the disengagement of the State from its own humanitarian objectives.

This situation has some implications for research. For instance resettlement workers' experience offers an entry point for the critical examination of how the State 'governs at a distance'. Drawing on Governmentality studies we could explore the rationality behind this particular way in which the State on the one hand delegates his humanitarian obligations to community organizations and on the other does not provide them with the necessary resources.

It is hoped that this thesis has raised significant questions regarding the difficult conditions under which resettlement workers receive and integrate GARs. It is believed that this thesis has shown that there are significant reasons to re-evaluate the model used to resettle GARs in Québec and that forces resettlement workers to mediate the inadequacy of the State to provide the necessary services to those it seeks to protect. 


\subsection{Finding \#3: Resettlement is an ongoing accomplishment}

This thesis also demonstrated that refugee resettlement consists of a series of coordinated work processes that occur across borders. Resettlement is the result of the ongoing coordination of the work of refugees as well as that of others such as UNHCR staff members, visa officers, IOM staff and civil servants. Therefore, a comprehensive study of refugee resettlement needs to address the work of refugees and the work of other actors within the resettlement process. Since it is an ongoing event, resettlement cannot be studied as a thing: it needs to be studied 'in motion' i.e. with a particular attention to the sequencing of work processes and to how these are coordinated. This thesis argued that IE offers conceptual tools that allow us to do so.

An understanding of refugee resettlement as a series of work processes that are interconnected can make a contribution to the ways in which policy makers attend to it. By taking into account how the work of everyone in the process coordinates, resettlement could not only be organized more efficiently but also more coherently. In fact, this study has shown that there is a disconnect between the decisions made at the government level in terms of capacity for resettlement and the actual resources of community organization for the reception and integration of GARs.

For instance, resettlement workers need to mediate the disjuncture between health needs of refugees (as identified abroad through medical examinations and incorporated into the textual organization of refugee resettlement by the visa officer) and the lack of access to healthcare in the Gatineau region. How does it happen that people with significant health-related problems are sent to a city like Gatineau where there is a known and documented problem of access to health care services? This needs to be addressed not only at the level of research but also at policy level. 


\subsection{Areas for future research}

In chapter 4 we have seen that waiting in camps or in cities involves the ongoing negotiation of one's life "in transit" and of the constant uncertainty about one's future. ${ }^{44}$ Refugees are at work as they wait; they try to find out how things work and what they can do to accelerate the processing of their case, they manage their anxiety and their frustration as they see other people leaving, they attempt to deal with their mixed feelings of relief and worries as they go through the final, yet everlasting, stage of the process. They then have to let go of their waiting work and hurry up before being sent by plane to another country of which they know but generalities. Resettlement work is but one of the many facets of the (re)production of refugee resettlement. The temporal and material constraint of this research prevented me from moving the institutional ethnographic gaze to the actual production of institutional processes beyond or above the local experience of refugees. Camp life and refugee resettlement are highly embedded in various discourses and sets of relations that extend well beyond the camp's fence and as such constitute an extremely fertile ground for an institutional ethnographic analysis. Without using the lexicon of IE, Hyndman (2000) clearly depicts the ruling relations coordinating refugees and camp life:

The spaces of refugee camps are in policy and in practice (though these are not necessarily the same) structured according to supralocal understandings of local needs. That is to say, the UNHCR organizes camps, ostensibly with the shelter, provision, and protection needs of refugees in mind. But on the ground their organization looks quite different. Once inside the camps, it appears that they meet the security and logistical needs of the humanitarian organization at least as much as those of refugees. Refugees living in camps are both incorporated by and incorporate this supralocal geography through their own cultural practices, which include a gendered distribution of labour and specific expressions of social organization. (Hyndman, 2000, p. 88)

\footnotetext{
${ }^{44}$ For instance, at one point during his exile in Nairobi, Mr. Banga once asked himself "mais finalement qu'est-ce que je vais devenir?"'
} 
More research is required into the ways in which these 'supralocal understandings of local needs' coordinate the experiences of the people at work in the camp (including refugees). Such research would need to collect observational and interview data on the work performed by those who manage refugee camps.

Another important limitation of this thesis is the fact that all GARs informants are male. As Hyndman suggests above, a gendered distribution of labour does exist in camps. It is presumably the case that this division of labour according to gender translates into a gendered division of 'work' (in a Smithian sense) that could not be addressed in this thesis. In fact more research is needed on the impact of gender on the unfolding of refugee resettlement. For instance, during this research I was struck by the emphasis on the concept of 'head of the family' in the various forms that refugees needed to sign during the resettlement process. This suggest that gender is perhaps textually (re)produced throughout resettlement.

Since refugee resettlement has been understudied, the list of studies that should be made would go on forever. In the Canadian context, it can be argued that research on refugee resettlement and on GARs is becoming more crucial as GARs are increasingly considered 'the deserving' refugees in opposition to the asylum seekers who are deemed 'illegal' (Saillant, 2007). This situation, which from the standpoint of refugee protection is reprehensible, calls for more research on resettlement and GARs. In fact, more should be known about the resettlement process and about the conditions under which GARs are being integrated into Canadian society so that Canada can better fulfill its humanitarian objectives. 


\section{References}

Beiser, M. (2006). Longitudinal Research to Promote Effective Refugee Resettlement. Transcultural Psychiatry, 43(1), 56-77.

Black, R. (2001). Fifty Years of Refugee Studies: From Theory to Policy. International Migration Review, 35(1), 57-78.

Bourdieu, P. (1990). The Logic of Practice (R. Nice, Trans.). Stanford: Stanford University Press.

Burchell, G., Gordon, C., \& Miller, P. (1991). The Foucault Effect: Studies in Govenmentality: With Two Lectures by and an Interview with Michel Foucault. Chicago: University of Chicago Press.

Campbell, M., \& Gregor, F. (2008). Mapping Social relations: A Primer in Doing Institutional Ethnography. Toronto: University of Toronto Press.

Casasola, M. (2001). Current Trends and New Challenges for Canada's Resettlement Program. Refuge, 19(4), 76-83.

CCR. (2011). Nairobi: Long delays - Statement on responding to African refugees. Retrieved from ccrweb.ca/files/nairobistatement.pdf.

Chimni, B. S. (1998). From resettlement to involuntary repatriation: towards a critical history of durable solutions to refugee problems: UNHCR.

Chimni, B. S. (2009). The Birth of a 'Discipline': From Refugee to Forced Migration Studies. Journal of Refugee Studies, 22(1), 11-29.

CIC. (2010). OP 5: Overseas Selection and Processing of Convention Refugees Abroad Class and Members of the Humanitarian-protected Persons Abroad Classes. Retrieved from http://www.cic.gc.ca/english/resources/manuals/op/op05-eng.pdf.

CMHC. (Spring 2011). Rental Market report: Québec Highlights.

Darville, R. (1995). Literacy, Experience, Power. In M. Campbell \& A. Manicom (Eds.), Knowledge, Experience and Ruling Relations: Studies in Social Organization of Knowledge (pp. 249-261). Toronto: University of Toronto Press.

Department of Labour. (2008). Refugee Resettlement: A Literature Review. Wellington: Government of New Zealand.

Devault, M. L. (Ed.). (2008). People at Work: Life, Power, and Social Inclusion in the New Economy. New York: New York University Press.

DeVault, M. L., \& McCoy, L. (2006). Institutional Ethnography: Using Interviews to Investigate Ruling Relations. In D. E. Smith (Ed.), Institutional Ethnography as Practice (pp. 15-44). Oxford: Rowman \& Littlefield Publishers, inc. .

Deveau, J. L. (2008). Examining the Institutional Ethnographer's Toolkit. Socialist Studies, 4(2), 1-20.

DeVoretz, D., Pivnenko, S., \& Beiser, M. (2004). The Economic Experiences of Refugees in Canada. Bonn: Institute for the Study of Labor.

Diamond, T. (1995). Making Grey Gold: Narratives of Nursing Home Care. Chicago: University of Chicago Press.

Diamond, T. (2006). 'Where Did You Get the Fur Coat, Fern?": Participant Observation in Institutional Ethnography. In D. E. Smith (Ed.), Institutional Ethnography as Practice (pp. 45-63). Oxford: Rowan \& Littlefield Publishers, inc.

Dobson, S. (2004). Culture of Exile and the Experience of Refugeeness. Bern: Peter Lang. 
Fairfield, P. (2000). Hermeneutical Pragmatism Theorizing Praxis: Studies in Hermeneutical Pragmatism (pp. 1-32). New York: Peter Lang.

Frampton, C., Kinsman, G., Thompson, A., \& Tilleczek, K. (2006). Sociology For Changing The World: Social Movements / Social Research. Halifax: Fernwood Publishing.

Francis, J. (Producer). (2009). "You Cannot Settle Like This": The Housing Situation of African Refugees in Metro Vancouver. Working Paper Series. Retrieved from http://www.mbc.metropolis.net/assets/uploads/files/wp/2009/WP09-02.pdf

Grahame, P. R. (2004). Ethnography, Institutions, and the Problematic of the Everyday World. In W. K. Carroll (Ed.), Critical Strategies for Social Research (pp. 181190). Toronto: Canadian Scholars' Press.

Gregor, F. M. (1994). The Social Organization of Nurses' Educative Work. Unpublished Doctoral Dissertation, Dalhousie University, Halifax.

Gregor, F. M. (2001). Nurses' Informal Teaching Practices: Their Nature and Impact on the Production of Patient Care. International Journal of Nursing Studies, 38, 461470.

Gurzu, A., \& Berthiaume, L. (2010). Kenney accused of using UN refugees as 'blackmail' to pass reforms, Embassy. Retrieved from http://www.embassymag.ca/page/view/refugees-03-31-2010

Guyon, S. (2011). La réinstallation des réfugiés sélectionnés à l'étranger au Québec, un secret bien gardé ! INSCAN, 24(3-4), 16-18.

Hathaway, J. C. (2007). Forced Migration Studies: Could We Agree Just to 'Date'? Journal of Refugee Studies, 20(3), 349-370.

Hyndman, J. (2000). Managing Displacement: Refugees and the Politics of Humanitarianism. Minneapolis: University of Minessota Press.

Jimenez, E. (2004). L'Accueil des réfugiés est rentable pour le Canada. Canadian Issues.

Kagan, M. (2002-2003). Is Truth in the Eye of the Beholder?: Objective Credibility Assessment in Refugee Status Determination. Georgetown Immigration Law Journal, $17(3), 367-415$.

Kagan, M. (2006). The Beleaguered Gatekeeper: Protection Challenges Posed by UNHCR Refugee Status Determination. International Journal of Refugee Law, 18(1), 1-29.

Knowles, V. (2007). Strangers at Our Gates: Canadian Immigration and immigration Policy, 1540-2006 (Revised ed.). Toronto: Dundurn Press.

Labman, S. (2007). Resettlement's Renaissance: A Cautionary Advocacy. Refuge, 24(2), $35-47$.

Lafortune, L. (January 28, 2010). Logemen'occupe dénonce l'inaction de Gatineau, Le Droit. Retrieved from http://www.cyberpresse.ca/le-droit/actualites/gatineauoutaouais/201001/28/01-943992-logemenoccupe-denonce-linaction-degatineau.php

Lamba, N., \& Krahn, H. (2003). Social capital and refugee resettlement: The social networks of refugees in Canada. Journal of International Migration and Integration, 4(3), 335-360. doi: 10.1007/s12134-003-1025-Z

Lippert, R. (1998). Rationalities and Refugee Resettlement. Economy and Society, 27(4), 308-406. 
Loescher, G., Betts, A., \& Milner, J. (2008). The United Nations High Commissioner for Refugees (UNHCR): The Politics and Practice of Refugee Protection into the Twenty-First Century. London: Routledge.

Loescher, G., \& Milner, J. (2003). The Missing Link: The Need for Comprehensive Engagement in Regions of Refugee Origin. International Affairs, 79(3), 583-617.

Loescher, G., \& Scanlan, J. (1986). Calculated Kindness: Refugees and America's HalfOpen Door. New York: Free Press.

Logemen'Occupe. (2011). Le respect du droit au logement avant la lutte au déficit: Mémoire de Logemen'occupe présenté au Ministre des Finances du Québec M. Raymond Bachand. Retrieved from http://www.entraidefamiliale.com/assets/textes-pdf/Mmoire-deLogemenoccupe.pdf

Macklin, A. (2007). Who Is the Citizen's Other? Considering the Heft of Citizenship. Theoretical Inquiries in Law, 8(2), 333-336.

Manicom, A. (1995). "What's health got to do with it?" Class, Gender and Teachers' Work. In M. Campbell \& A. Manicom (Eds.), Knowledge, Experience and Ruling Relations: Studies in the Social Organization of Knowledge (pp. 135-148). Toronto: University of Toronto Press.

Marx, K., \& Engels, F. (1978). The German Ideology: Part I. In R. C. Tucker (Ed.), The Marx-Engels Reader (Second ed., pp. 147-200). New York: W.W. Norton \& Company.

McCoy, L. (1995). Activating the Photographic Text. In M. Campbell \& A. Manicom (Eds.), Kowledge, Experience, and Ruling Relations: Studies in the Social Organization of Knowledge (pp. 181-192). Toronto: University of Toronto Press.

McCoy, L. (2006). Keeping the Institution in View: Working with Interview Accounts of Everyday Experience. In D. E. Smith (Ed.), Institutional Ethnography as Practice (pp. 109-125). Oxford: Rowman \& Littlefield Publishers, Inc.

McKeary, M., \& Newbold, B. (2010). Barriers to Care: The Challenges for Canadian Refugees and their Health Care Providers. Journal of Refugee Studies, 23(4), 523 545.

Mercier, J. (2011). Les orphelins font la file à $-20^{\circ} \mathrm{C}$, Le Droit. Retrieved from http://www.cyberpresse.ca/le-droit/actualites/gatineau-outaouais/201102

MICC. (2006). Guide des Procédures d'Immigration Composante 2: Immigration Humanitaire. Retrieved from http://www.micc.gouv.qc.ca.

MICC. (2010). La sélection, l'accueil et l'intégration des réfugiés pris en charge par l'État et parrainés au Québec.

Michalski, J. H. (2001). The Challenges of Resettlement among Male, GovernmentAssisted Iraqi Refugees in Canada. Journal of Social Work Research and Evaluation, 2.

Miller, P., \& Rose, N. (2008). Governing the Present. Cambridge: Polity Press.

Milner, J. (2005). Resettlement. In M. J. Gibney \& R. Hansen (Eds.), Immigration and Asylum: from 1900 to the present. Santa Barbara: ABC-Clio.

Milner, J. (2009). Refugees, the State and the Politics of Asylum in Africa. Basingstoke: Palgrave Macmillan.

Moulin, C., \& Nyers, P. (2007). "We Live in a Country of UNHCR"-Refugee Protests and Global Political Society. International Political Sociology, 1(4), 356-372. 
Murdie, R. (2010). Precarious Beginnings: The Housing Situation of Canada's Refugees. Canadian Issues(Fall), 47-51.

Mykhalovskiy, E., \& McCoy, L. (2002). Troubling Ruling Discourses of Health: Using Institutional Ethnography in Community-based Research. Critical Public Health, $12(1), 17-37$.

Ng, R. (1996). The Politics of Community Services: Immigrant Women, Class and State. Halifax: Fernwood Publishing.

Nyers, P. (2006). Rethinking Refugees: Beyound States of Emergency. New York: Routledge.

Orr, B. (2004). Resettlement: A Durable Solution. Canadian Issues(spring), 22-27.

Rose, N. (1993). Government, Authority and Expertise in Advanced Liberalism Economy and Society, 22(3), 283-299.

Rose, N. (1996). The Death of the Social? Re-figuring the Territory of Government. Economy and Society, 25(3), 327-356.

Rose, N. (1999). Powers of Freedom: Reframing Political Thought. Cambridge: Cambridge University Press.

Saillant, F. (2007). "Vous êtes ici dans une mini-ONU" : les réfugiés publics au Québec. De l'humanitaire au

communautaire. Anthropologie et Sociétés, 31(2), 65-90.

Sherrell, K. (2010). Legal Status, Place, or Something Else? The Housing Experiences of Refugees in Winninpeg and Vancouver. Canadian Issues(Fall), 52-57.

Simich, L. (2003). Negotiating Boundaries of Refugee Resettlement: A Study of Settlement Patterns and Social Support. Canadian Canadian Review of Sociology and Anthropology, 40(5), 575-591.

Simich, L., Beiser, M., \& Mawani, F. (2002). Paved with Good Intentions: Canada's Refugee Destining Policy and Paths of SecondaryM igration. Canadian Public Policy, XXVIII(4), 597-607.

Simich, L., Beiser, M., Mawani, F., \& O'Hare, J. (2001). Paved with Good Intentions: Paths of Secondary Migration Of Government-Assisted Refugees in Ontario. Toronto: Ontario Administration of Settlement and Integration Services, CIC.

Smith, D. E. (1987). The Everyday World as Problematic: A Feminist Sociology. Boston: Northeastern University Press.

Smith, D. E. (1990a). The Conceptual Practices of Power: A Feminist Sociology of Knowledge. Boston: Northeastern University Press.

Smith, D. E. (1990b). Texts, Facts, and Femininity : Exploring the Relations of Ruling. New York: Routledge.

Smith, D. E. (1999a). From Women's Strandpoint to a Sociology for People. In J. L. AbuLughod (Ed.), Sociology for the twenty-first century: continuities and cutting edges (pp. 65-82). Chicago: University of Chicago Press.

Smith, D. E. (1999b). Writing the Social: Critique, Theory, and Investigations. Toronto: University of Toronto Press.

Smith, D. E. (2005). Institutional Ethnography: A Sociology for People. Oxford: Alta Mira Press.

Smith, D. E. (Ed.). (2006). Institutional Ethnography as Practice. Oxford: Rowman \& Littlefield, Inc.

Smrkolj, M. (2010). International Institutions and Individualized Decision-Making: An Example of UNHCR's Refugee Status Determination. In A. v. Bogdandy, R. 
Wolfrum, J. V. Bernstorff, P. Dann \& M. Goldmann (Eds.), The Exercise of Public Authority by International Institutions: Advancing International Institutional Law (pp. 165-193). Heidelberg: Springer.

Spitzer, D. L. (2006). The Impact of Policy on Somali Refugee Women in Canada. Refuge, 23(2), 47-54.

UNHCR. (1992). Handbook on Procedures and Criteria for Determining Refugee Status under the 1951Convention and the 1967 Protocol relating to the Status of Refugees. Retrieved from

UNHCR. (2001). Background Note for the Agenda Item: Strategic Utilization of Resettlement to Enhance Asylum and Protection Prospects. Paper presented at the Annual Tripartite Consultations on Resettlement, 20 june, Geneva.

UNHCR. (2004). Resettlement Handbook. Geneva: United Nations High Commissioner for Refugees.

UNHCR. (2010). UNHCR Projected Global Resettlement Needs 2011. Retrieved from

UNHCR. (2011a). 60 Years and Still Counting: UNHCR Global Trends 201. Retrieved from http://www.unhcr.org/4dfa1 1499.html

UNHCR. (2011b). Resettlement Fact Sheet 2011.

Voloshinov, V. (1973). Marxism and the Philosophy of Language (L. Matejka \& I. R. Titunik, Trans.). Cambridge: Harvard University Press.

Walby, K. (2005). How Closed-Circuit Television Surveillance Organizes the Social: an Institutional Ethnography. Canadian Journal of Sociology, 30(2), 189-214.

Walby, K. (2007). On the Social Relations of Research: Critical Assessment of Institutional Ethnography. Qualitative Inquiry, 13(7), 1008-1030.

Zetter, R. (1991). Labeling Refugees: Forming and Transforming a Bureaucratic Identity. Journal of Refugee Studies, 4(1), 39-62.

Zetter, R. (2007). More Labels, Fewer Refugees: Remaking the Refugee Label in an Era of Globalization. Journal of Refugee Studies, 20(2), 172-192. 
Appendix A

Letters of Information 
(Participants RPCE)

Titre du projet de recherche: Starting from Refugees Themselves: A Study of the Social Organization of Refugee Resettlement (tentative title)

(Partir des réfugiés eux-mêmes: une étude de l'organisation sociale du réétablissement des réfugiés)

Date d'approbation du comité d'éthique: 11 mars 2011

Bonjour,

Mon nom est Christophe Allaire Sévigny et je suis étudiant à la maîtrise au département de sociologie et d'anthropologie de l'université Carleton à Ottawa. J'aimerais vous inviter à prendre part à une étude sur 1'organisation du réétablissement des réfugiés au Canada. Cette recherche se déroule sous la supervision de Dr Daiva Stasiulis du département de sociologie et d'anthropologie de l'université Carleton.

Les expériences de réétablissement des réfugiés pris en charge par l'État (RPCE) ainsi que le travail effectué par les travailleurs communautaires, les fonctionnaires et les employés du Haut Commissariat pour les Réfugiés (HCR) constituent un point de départ essentiel pour l'étude du réétablissement des réfugiés au Canada. Le but de ma recherche est de cartographier les processus institutionnels du réétablissement des réfugiées en partant des expériences vécues des RPCE afin d'en découvrir le fonctionnement. Plus précisément, cette recherche vise à voir de quelle façon l'organisation du réétablissement des réfugiés au Canada est lié au régime international de protection des réfugiés et de quelle manière cela affecte les expériences de réétablissement des RPGs.

En tant que participant à cette étude vous serez conviés à participer à une entrevue. Cette entrevue durera environ une heure et les questions que je poserai concerneront les différentes étapes du réétablissement comme par exemple le processus de sélection à l'étranger, la préparation des documents, l'arrivée au Canada, etc. L'entrevue sera enregistrée afin de faciliter mon travail d'analyse et ce, seulement si vous y consentez. L'entrevue aura normalement lieu dans les locaux d'Accueil-Parrainage Outaouais (APO).

Puisque le sujet de l'entrevue en est un personnel et individuel, il est convenu que cette recherche comporte peu de risques pour les participants. À titre d'exemple, si vous désirez aborder plus en détail des expériences traumatisantes c'est votre choix, mais vous devez être conscient que ceci peut entrainer des réactions émotives difficiles.

Votre participation à l'entrevue est entièrement volontaire et vous pourrez refuser de répondre une ou plusieurs question (s) et ce, sans avoir à vous justifier. Vous pourrez retirer votre consentement à participer à n'importe quel moment de l'étude et vous pourrez aussi demander à ce que les données amassées lors de l'entrevue ne soient pas utilisées. Cependant après le $1^{\text {er }}$ mai 2011 il ne sera plus possible de retirer les données que vous aurez fournies.

Je serai, avec ma superviseure (Dr Daiva Stasiulis) et le membre de mon comité de mémoire (Dr James Milner) seul à avoir accès aux données fournies. Ces données seront emmagasinées dans un classeur verrouillé dans le bureau de Dr Stasiulis ainsi que sur des fichiers informatiques protégés qui seront enregistrés sur clé USB. Les données seront 
gardées indéfiniment comme c'est la convention dans la plupart des études sociologiques (à des fins d'analyses ultérieures, de reproduction de recherches similaires, ou de recherches futures sur le sujet).

Votre identité sera protégée en vertu du fait que votre nom n'apparaitra jamais dans aucune publication qui résultera de cette recherche. De plus, les citations ne seront jamais attribuées aux gens par leur nom. En plus, tous les efforts seront faits afin d'effacer toute trace d'identificateurs personnels des données qui résulteront de l'entrevue. Cependant, dû au fait que l'échantillon de participants est tiré en utilisant une combinaison d'échantillonnage raisonné et d'échantillonnage « boule de neige » l'anonymat ne peu pas être garantie.

Il n'y a pas de bénéfices directs et immédiats pour les participants à la recherche. Cependant, cette étude amènera une nouvelle lecture du processus de rétablissement des réfugiés au Canada en abordant de façon empirique la manière dont les expériences de réétablissement des RPCE sont coordonnées ainsi que la façon dont le travail des agents de réétablissement est relié à celui des fonctionnaires provinciaux et fédéraux et à celui des employés du HCR. Vous pourrez avoir une copie de mon mémoire si vous le désirez.

Si après avoir reçu cette lettre vous avec quelques questions que ce soit à propos de cette étude ou si vous voulez de l'information supplémentaire afin de prendre une décision par rapport à votre participation s'il vous plaît n'hésitez pas à me le demander.

Je vous confirme que cette étude a reçu l'approbation du comité d'éthique de recherche de l'Université Carleton.

Merci d'accorder de l'intérêt à mon projet de recherche et de le soutenir par votre participation.

Vous pouvez me contacter ainsi que ma superviseure pour toutes questions relatives à la présente recherche :

\section{Chercheur étudiant :}

Christophe Allaire Sévigny

Department of Sociology and Anthropology

Carleton University

Ottawa, Ontario

K1S 5B6

Tel.

Courriel: casevign.connect.carleton.ca
Superviseure de Recherche:

Professor Daiva Stasiulis

Department of Sociology and Anthropology

Carleton University

Ottawa, Ontario

K1S 5B6

Tel. (613) 520-2600 ext. 1088

Courriel:

Vous pouvez contacter la personne suivante pour toutes questions relatives à l'éthique ou pour toutes plaintes:

Comité d'éthique de l'Université Carleton:

Prof. Antonio Gualtieri, Président

Research Ethics Board

510B Tory Building

Carleton University

(613) 520-2517

ethics@,carleton.ca 


\section{Lettre d'information \\ (Participants non-réfugiés)}

Titre du projet de recherche: Starting from Refugees Themselves: A Study of the Social Organization of Refugee Resettlement

(Partir des réfugiés eux-mêmes: une étude de l'organisation sociale du réétablissement des réfugiés)

Date d'approbation du comité d'éthique: 11 mars 2011

Bonjour,

Mon nom est Christophe Allaire Sévigny et je suis étudiant à la maîtrise au département de sociologie et d'anthropologie de l'université Carleton à Ottawa. J'aimerais vous inviter à prendre part à une étude sur l'organisation du réétablissement des réfugiés au Canada. Cette recherche se déroule sous la supervision de Dr Daiva Stasiulis du département de sociologie et d'anthropologie de l'université Carleton.

Les expériences de réétablissement des réfugiés pris en charge par l'État (RPCE) ainsi que le travail effectué par les travailleurs communautaires, les fonctionnaires et les employés du Haut Commissariat pour les Réfugiés (HCR) constituent un point de départ essentiel pour l'étude du réétablissement des réfugiés au Canada. Le but de ma recherche est de cartographier les processus institutionnels du réétablissement des réfugiées en partant des expériences vécues des RPCE afin d'en découvrir le fonctionnement. Plus précisément, cette recherche vise à voir de quelle façon l'organisation du réétablissement des réfugiés au Canada est liée au régime international de protection des réfugiés et de quelle manière cela affecte les expériences de réétablissement des RPCE.

En tant que participant à cette étude vous serez conviés à participer à une entrevue. Cette entrevue durera environ une heure et les questions que je poserai concerneront le type de travail effectué dans le cadre du rétablissement des réfugiés. L'entrevue sera enregistrée afin de faciliter mon travail d'analyse et ce, seulement si vous y consentez. L'entrevue aura normalement lieu dans votre lieu de travail ou tout autre endroit que vous choisirez.

Il est convenu que cette recherche comporte peu de risques pour les participants. Votre participation à l'entrevue est entièrement volontaire et vous pourrez refuser de répondre une ou plusieurs question (s) et ce, sans avoir à vous justifier. Vous pourrez retirer votre consentement à participer à n'importe quel moment de l'étude et vous pourrez aussi demander à ce que les données amassées lors de l'entrevue ne soient pas utilisées. Cependant après le 15 juin 2011 il ne sera plus possible de retirer les données que vous aurez fournies.

Je serai, avec ma superviseure (Dr Daiva Stasiulis) et le membre de mon comité de mémoire (Dr James Milner) seul à avoir accès aux données fournies. Ces données seront emmagasinées dans un classeur verrouillé dans le bureau de Dr Stasiulis ainsi que sur des fichiers informatiques protégés qui seront enregistrés sur clé USB. Les données seront gardées indéfiniment comme c'est la convention dans la plupart des études sociologiques (à des fins d'analyses ultérieures, de reproduction de recherches similaires, ou de recherches futures sur le sujet).

Votre identité sera protégée en vertu du fait que votre nom n'apparaitra jamais dans aucune publication qui résultera de cette recherche. De plus, les citations ne seront jamais attribuées aux gens par leur nom. Cependant, dû au fait 
que l'échantillon de participants est tiré en utilisant une combinaison d'échantillonnage raisonné et d'échantillonnage «boule de neige » l'anonymat ne peu pas être garantie.

Il n’y a pas de bénéfices directs et immédiats pour les participants à la recherche. Cependant, cette étude amènera une nouvelle lecture du processus de rétablissement des réfugiés au Canada en abordant de façon empirique la manière dont les expériences de réétablissement des RPCE sont coordonnées ainsi que la façon dont le travail des agents de réétablissement est relié à celui des fonctionnaires provinciaux et fédéraux et à celui des employés du HCR. Vous pourrez avoir une copie de mon mémoire si vous le désirez.

Si après avoir reçu cette lettre vous avez quelques questions que ce soit à propos de cette étude ou si vous voulez de l'information supplémentaire afin de prendre une décision par rapport à votre participation, n'hésitez pas à me le demander.

Je vous confirme que cette étude a reçu l'approbation du comité d'éthique de recherche de l'Université Carleton.

Merci d'accorder de l'intérêt à mon projet de recherche et de le soutenir par votre participation.

Vous pouvez me contacter ainsi que ma superviseure pour toutes questions relatives à la présente recherche :

Chercheur étudiant :

Christophe Allaire Sévigny

Department of Sociology and Anthropology

Carleton University

Ottawa, Ontario

K1S 5B6

Tel.

Courriel: casevign.connect.carleton.ca
Superviseure de Recherche:

Professor Daiva Stasiulis

Department of Sociology and Anthropology

Carleton University

Ottawa, Ontario

K1S 5B6

Tel. (613) 520-2600 ext. 1088

Courriel:

Vous pouvez contacter la personne suivante pour toutes questions relatives à l'éthique ou pour toutes plaintes:

\section{Comité d'éthique de l'Université Carleton:}

Prof. Antonio Gualtieri, Président

Research Ethics Board

$510 \mathrm{~B}$ Tory Building

Carleton University

(613) 520-2517

ethics@carleton.ca 
Appendix B

Consent Forms 


\section{Canadas Capilal Universily}

\section{Formulaire de Consentement \\ (Pour Participants RPCE)}

Titre du projet de recherche: Starting from Refugees Themselves: An Institutional Ethnography of Refugee Resettlement in Quebec (Working Title)

(Partir des réfugiés eux-mêmes: une ethnographie institutionnelle du réétablissement des réfugiés au Québec)

Date d'approbation du comité d'éthique : 11 mars 2011

L'approbation du comité d'éthique est valide jusqu'au 31 mai 2011

Je consens à être interviewé par Christophe Allaire Sevigny

du département de sociologie et d'anthropologie de l'université Carleton à Ottawa dans le cadre de sa recherche intitulée «Starting from Refugees Themselves: An Institutional Ethnography of Refugee Resettlement in Quebec».

Les expériences de réétablissement des réfugiés pris en charge par l'État (RPCE) ainsi que le travail effectué par les travailleurs communautaires, les fonctionnaires et les employés du Haut Commissariat pour les Réfugiés (HCR) constituent un point de départ essentiel pour l'étude du réétablissement des réfugiés au Canada. Le but de ma recherche est de cartographier les processus institutionnels du réétablissement des réfugiées en partant des expériences vécues des RPCE afin d'en découvrir le fonctionnement. Plus précisément, cette recherche vise à voir de quelle façon l'organisation du réétablissement des réfugiés au Canada est liée au régime international de protection des réfugiés et de quelle manière cela influence les expériences de réétablissement des RPCE

Cette entrevue durera environ une heure et les questions que je poserai concerneront les différentes étapes du réétablissement comme par exemple le processus de sélection à l'étranger, la préparation des documents, l'arrivée au Canada, etc. L'entrevue sera enregistrée afin de faciliter mon travail d'analyse, et ce, seulement si vous y consentez. L'entrevue aura normalement lieu dans les locaux d'Accueil-Parrainage Outaouais (APO).

Je consens à être enregistré :

Je ne consens pas à être enregistré:

Puisque le sujet de l'entrevue en est un personnel et individuel, il est convenu que cette recherche comporte peu de risques pour les participants. Cependant, si je décide d'aborder plus en détail des expériences traumatisantes c'est mon choix et je suis conscient que ceci peut entrainer des réactions émotives difficiles.

Ma participation à l'entrevue est entièrement volontaire et je pourrai refuser de répondre une ou plusieurs question (s) et ce, sans avoir à me justifier. Je pourrai retirer mon consentement à participer à n'importe quel moment de l'étude et je pourrai aussi demander à ce que les données amassées lors de l'entrevue ne soient pas utilisées. Je comprends cependant qu'après le $1^{\text {er }}$ mai 2011 il ne sera plus possible de retirer les données que j'aurai fournies.

Je comprends que seulement le chercheur principal (Christophe Allaire Sévigny), sa superviseure (Dr Daiva Stasiulis) ainsi que le membre de son comité de mémoire (Dr James Milner) pourront avoir accès aux données 
fournies. Ces données seront emmagasinées dans un classeur verrouillé dans le bureau de Dr Stasiulis ainsi que sur des fichiers informatiques protégés qui seront enregistrés sur clé USB. Les données seront gardées indéfiniment comme c'est la convention dans la plupart des études sociologiques (à des fins d'analyses ultérieures, de reproduction de recherches similaires, ou de recherches futures sur le sujet).

Mon identité sera protégée en vertu du fait que mon nom n'apparaitra dans aucune publication qui résultera de cette recherche. De plus, les citations ne seront jamais attribuées aux gens par leur nom. En plus, tous les efforts seront faits afin d'effacer toute trace d'identificateurs personnels des données qui résulteront de l'entrevue. Cependant, dû au fait que l'échantillon de participants est tiré en utilisant une combinaison d'échantillonnage raisonné et d'échantillonnage «boule de neige » l'anonymat ne peu pas être garantie.

Je comprends qu'il n'y a pas de bénéfices directs et immédiats pour les participants à cette recherche. Cependant, cette étude amènera une nouvelle lecture du processus de rétablissement des réfugiés au Canada en abordant de façon empirique la manière dont les expériences de réétablissement des RPCE sont coordonnées ainsi que la façon dont le travail des agents de réétablissement est relié à celui des fonctionnaires provinciaux et fédéraux et à celui des employés du HCR. Je pourrai voir une copie du mémoire résultant de cette recherche si je le désire.

Vous pouvez me contacter ainsi que ma superviseure pour toutes questions relatives à la présente recherche :

\section{Chercheur étudiant :}

Christophe Allaire Sévigny

Department of Sociology and Anthropology

Carleton University

Ottawa, Ontario

K1S 5B6

Tel.

Courriel: casevign.connect.carleton.ca
Superviseure de Recherche:

Professor Daiva Stasiulis

Department of Sociology and Anthropology

Carleton University

Ottawa, Ontario

K1S 5B6

Tel. (613) 520-2600 ext. 1088

Courriel: ,

Vous pouvez contacter la personne suivante pour toutes questions relatives à l'éthique ou pour toutes plaintes :

\section{Comité d'éthique de l'Université Carleton: \\ Prof. Antonio Gualtieri, Président}

Research Ethics Board

510B Tory Building

Carleton University

(613) 520-2517

ethics@carleton.ca

Christophe Allaire Sévigny

Date

Étudiant chercheur

Participant

Date 


\section{Carleton}

UNIVERSITY

Canada's Capital University

\section{Formulaire de Consentement (pour participants non-RPCE)}

Titre du projet de recherche: Starting from Refugees Themselves: An Institutional Ethnography of Refugee Resettlement in Quebec (working Title)

(Partir des réfugiés eux-mêmes: une ethnographie institutionnelle du réétablissement des réfugiés au Québec)

Date d'approbation du comité d'éthique : 11 mars 2011

L'approbation du comité d'éthique est valide jusqu'au 31 mai 2012

$\mathrm{Je}$ consens à être interviewé par Christophe Allaire Sevigny

du département de sociologie et d'anthropologie de l'université Carleton à Ottawa dans le cadre de sa recherche temporairement intitulée «Starting from Refugees Themselves: An Institutional Ethnography of Refugee Resettlement in Quebec».

Les expériences de réétablissement des réfugiés pris en charge par l'État (RPCE) ainsi que le travail effectué par les travailleurs communautaires, les fonctionnaires et les employés du Haut Commissariat pour les Réfugiés (HCR) constituent un point de départ essentiel pour l'étude du réétablissement des réfugiés au Canada. Le but de ma recherche est de cartographier les processus institutionnels du réétablissement des réfugiées en partant des expériences vécues des RPCE afin d'en découvrir le fonctionnement. Plus précisément, cette recherche vise à voir de quelle façon l'organisation du réétablissement des réfugiés au Canada est liée au régime international de protection des réfugiés et de quelle manière cela influence les expériences de rét́tablissement des RPCE.

Cette entrevue durera environ une heure et les questions concerneront le travail lié au réétablissement des réfugiés. L'entrevue sera enregistrée afin de faciliter le travail d'analyse, et ce, seulement si j'y consens. L'entrevue aura normalement lieu dans mon lieu de travail.

Je consens à être enregistré :

Je ne consens pas à être enregistré:

Il est convenu que cette recherche ne comporte pas de risques pour les participants. Ma participation à l'entrevue est entièrement volontaire et je pourrai refuser de répondre une ou plusieurs question (s) et ce, sans avoir à me justifier. Je pourrai retirer mon consentement à participer à n'importe quel moment de l'étude et je pourrai aussi demander à ce que les données amassées lors de l'entrevue ne soient pas utilisées. Je comprends cependant qu'après le 30 juin 2011 il ne sera plus possible de retirer les données que j'aurai fournies.

Je comprends que seulement le chercheur principal (Christophe Allaire Sévigny), sa superviseure (Dr Daiva Stasiulis) ainsi que le membre de son comité de mémoire (Dr James Milner) pourront avoir accès aux données fournies. Ces données seront emmagasinées dans un classeur verrouillé dans le bureau de Dr Stasiulis ainsi que sur des fichiers informatiques protégés qui seront enregistrés sur clé USB. Les données seront gardées indéfiniment comme c'est la convention dans la plupart des études sociologiques (à des fins d'analyses ultérieures, de reproduction de recherches similaires, ou de recherches futures sur le sujet). 
Mon identité sera protégée en vertu du fait que mon nom n'apparaitra dans aucune publication qui résultera de cette recherche. De plus, les citations ne seront jamais attribuées aux gens par leur nom. En plus, tous les efforts seront faits afin d'effacer toute trace d'identificateurs personnels des données qui résulteront de l'entrevue. Cependant, dû au fait que l'échantillon de participants est tiré en utilisant une combinaison d'échantillonnage raisonné et d'échantillonnage «boule de neige » l'anonymat ne peu pas être garantie.

Je comprends qu'il n'y a pas de bénéfices directs et immédiats pour les participants à cette recherche. Cependant, cette étude amènera une nouvelle lecture du processus de rétablissement des réfugiés au Canada en abordant de façon empirique la manière dont les expériences de réétablissement des RPCE sont coordonnées ainsi que la façon dont le travail des agents de réétablissement est relié à celui des fonctionnaires provinciaux et fédéraux et à celui des employés du HCR. Je pourrai voir une copie du mémoire résultant de cette recherche si je le désire.

Vous pouvez me contacter ainsi que ma superviseure pour toutes questions relatives à la présente recherche :

\section{Chercheur étudiant :}

Christophe Allaire Sévigny

Department of Sociology and Anthropology

Carleton University

Ottawa, Ontario

K1S 5B6

Tel.

Courriel: casevign.connect.carleton.ca

\section{Superviseure de Recherche:}

Professor Daiva Stasiulis

Department of Sociology and Anthropology

Carleton University

Ottawa, Ontario

K1S 5B6

Tel. (613) 520-2600 ext. 1088

Courriel: $c$

Vous pouvez contacter la personne suivante pour toutes questions relatives à l'éthique ou pour toutes plaintes :

Comité d'éthique de l'Université Carleton:

Prof. Antonio Gualtieri, Président

Research Ethics Board

510B Tory Building

Carleton University

(613) 520-2517

ethics@,carleton.ca

Signature du participant

Christophe Allaire Sévigny

Étudiant chercheur
Date

Date 